Prepared in cooperation with the Nevada Division of Water Resources

\title{
Analysis of Aquifer Framework and Hydraulic Properties of Lovelock Valley, Lovelock, Nevada
}

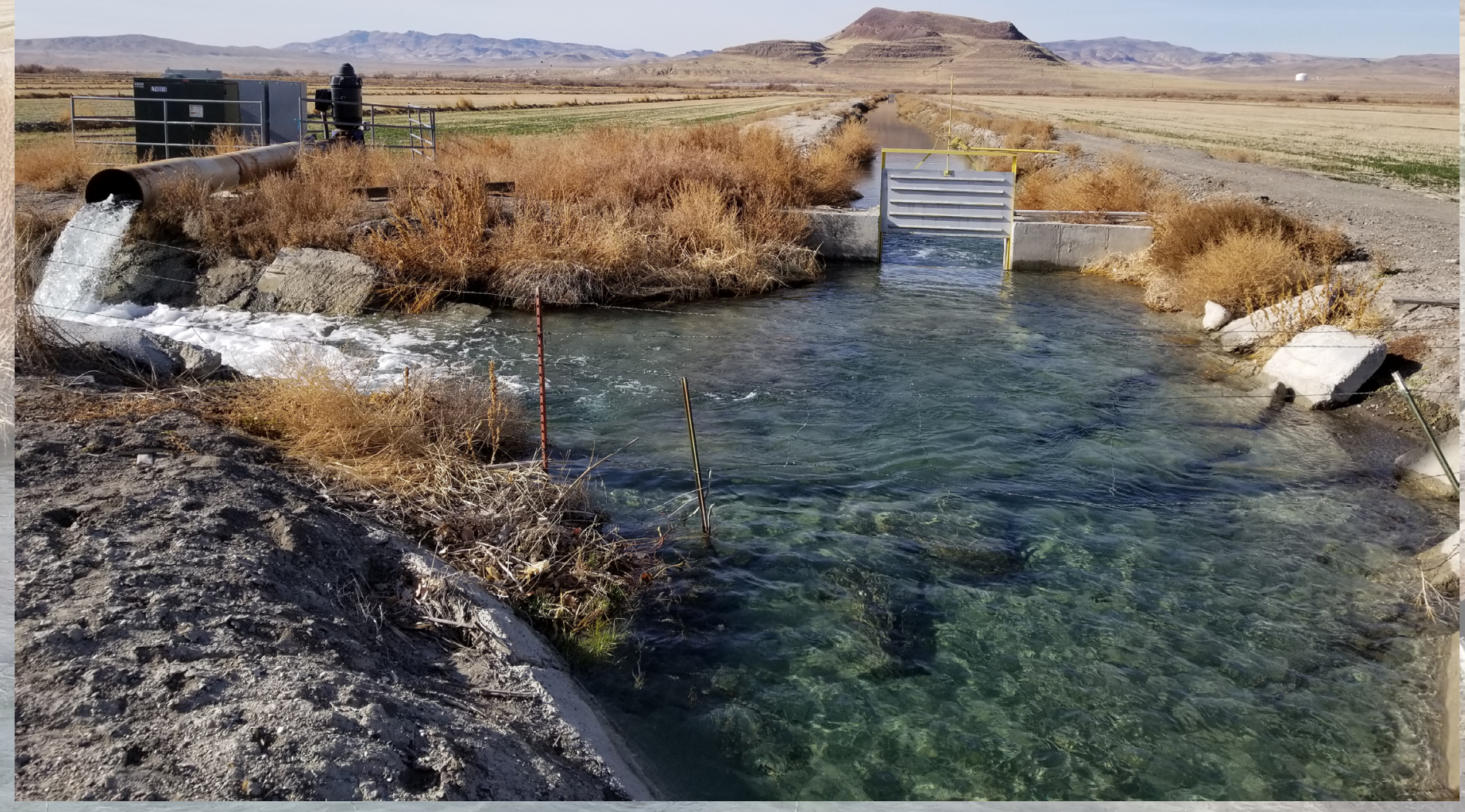

Open-File Report 2019-1133

U.S. Department of the Interior

U.S. Geological Survey 
Cover: Well 401142118294001 discharging water at a rate of 6,038 gallons per minute into a nearby canal in Lovelock Valley, Nevada. Photograph taken by Kyle 0'Connor, U.S. Geological Survey, on December 1, 2017. 


\section{Analysis of Aquifer Framework and Hydraulic Properties of Lovelock Valley, Lovelock, Nevada}

By Cara Nadler

Prepared in cooperation with the Nevada Division of Water Resources

Open-File Report 2019-1133 


\title{
U.S. Department of the Interior DAVID BERNHARDT, Secretary
}

\author{
U.S. Geological Survey \\ James F. Reilly II, Director
}

\section{U.S. Geological Survey, Reston, Virginia: 2020}

For more information on the USGS - the Federal source for science about the Earth, its natural and living resources, natural hazards, and the environment-visit https://www.usgs.gov or call 1-888-ASK-USGS.

For an overview of USGS information products, including maps, imagery, and publications, visit https://store.usgs.gov.

Any use of trade, firm, or product names is for descriptive purposes only and does not imply endorsement by the U.S. Government.

Although this information product, for the most part, is in the public domain, it also may contain copyrighted materials as noted in the text. Permission to reproduce copyrighted items must be secured from the copyright owner.

Suggested citation:

Nadler, C., 2020, Analysis of aquifer framework and hydraulic properties of Lovelock Valley, Lovelock, Nevada: U.S. Geological Survey Open-File Report 2019-1133, 48 p., https://doi.org/10.3133/ofr20191133.

Associated data for this publication:

Nadler, C.A., 2020, Supplemental data for analysis of aquifer framework and hydraulic properties of Lovelock Valley, Lovelock, NV: U.S. Geological Survey data release, https://doi.org/10.5066/P9LIL7PZ. 


\section{Acknowledgments}

We thank the residents of Lovelock, Nevada, who graciously allowed access to their wells.

This study would not have been possible without their cooperation. We also thank the Pershing

County Water Conservation District for sharing their local expertise. 


\section{Contents}

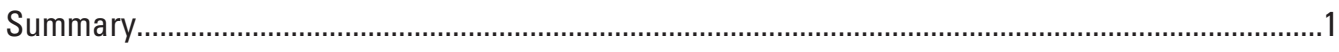

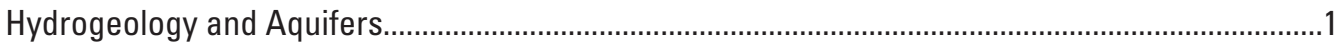

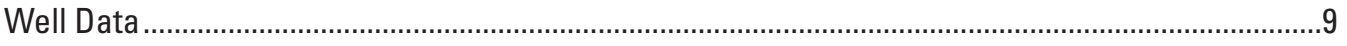

Transmissivities of the Lahontan Clays and Silts Evaluated from Slug Tests ....................................

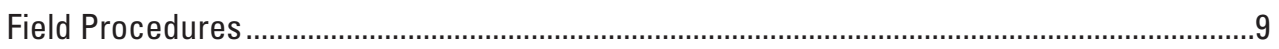

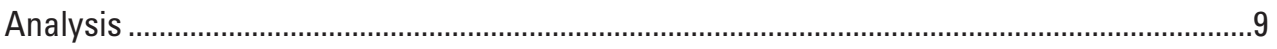

Transmissivity of the Coarser Alluvium Evaluated from a Slug Test ................................................14

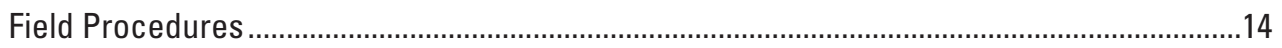

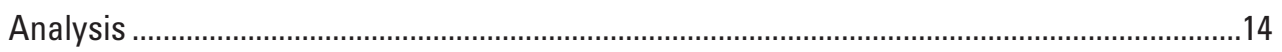

Transmissivity of the Coarser Alluvium Evaluated from a Single-Well Pumping Test......................16

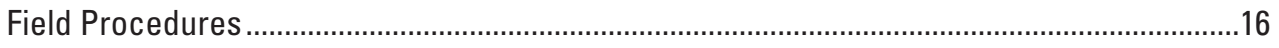

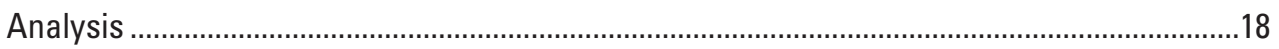

Transmissivity of the Lahontan Clays and Silts, Fluvial Deposits, and Coarser Alluvium Determined from two Multi-Well Pumping Tests ...............................................................19

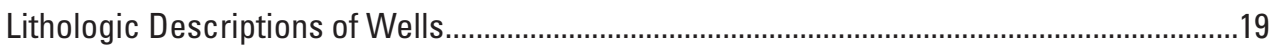

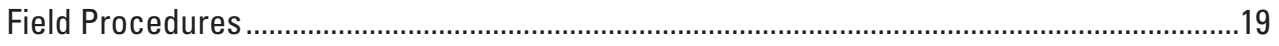

Multi-Well Pumping Test \#1 _.....................................................................................19

Multi-Well Pumping Test \#2 ….................................................................................24

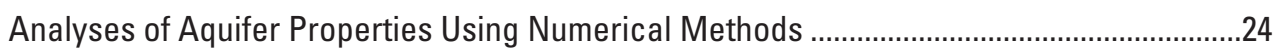

Estimated Drawdowns Using Water-Level Modeling.....................................................24

Multi-Well Pumping Test \#1 (MWP1) Water-Level Models ......................................27

Multi-Well Pumping Test \#2 (MWP2) Water-Level Models ...................................28

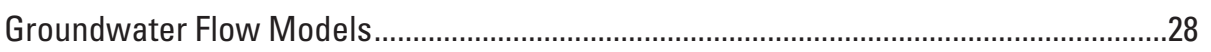

Parameter Estimation and Goodness of Fit ...............................................................29

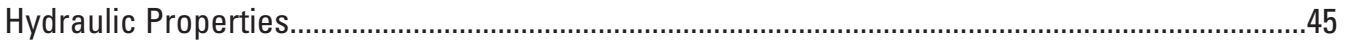

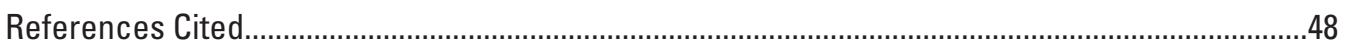




\section{Figures}

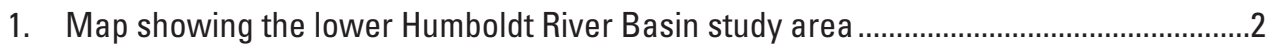

2. Map showing surface geology of the lower Humboldt River Basin, Nevada ....................3

3. Map showing lateral extent of two near-surface aquifers (fluvial deposits and Lahontan clays and silts) derived from Maurer and others (2004).

4. Map showing lateral extent of the deeper water-bearing aquifer (coarser alluvium) derived from Maurer and others (2004) .......................................................

5. Map showing wells used in the Lovelock Valley aquifer tests ........................................7

6. Map showing locations of Wells 6, 7, 12, 13, 15, 16, and the model domain for the forthcoming lower Humboldt River Basin capture study.............................................10

7. Graphs showing water level response and analysis of three injection slug tests conducted at Well 6..................................................................................................

8. Graphs showing water level response and analysis of three injection slug tests

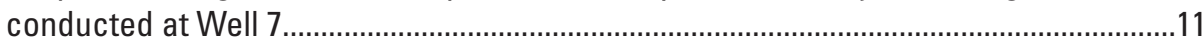

9. Graphs showing water level response and analysis of three injection slug tests

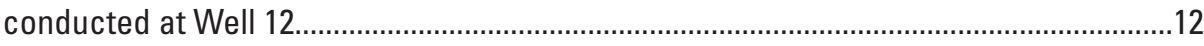

10. Graphs showing water level response and analysis of two injection slug tests

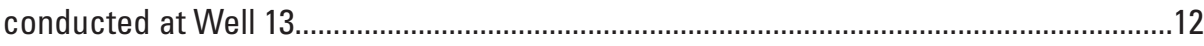

11. Graphs showing water level response and analysis of two injection slug tests conducted at Well $15 .$.

12. Graphs showing water level response and analysis of two injection slug tests conducted at Well 16 ...

13. Map showing location of Well 14 and the model domain for the lower Humboldt River Basin capture study.

14. Graphs showing water level response and analysis of three injection slug tests conducted at Well 14 ...

15. Map showing location of Well 3 and the model domain for the Lower Humboldt River Basin capture study ........................................................................................17

16. Graph showing Cooper-Jacob analysis of drawdown data for Well 3...........................18

17. Map showing location of Lovelock Valley multi-well pumping test \#1 showing the pumping well and seven observation wells.

18. Photograph showing pumping well discharging water at a rate of 4,400 gallons

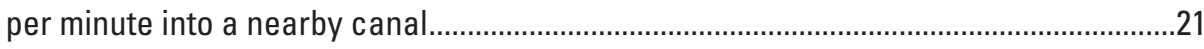

19. Aerial photograph showing water discharge path from the pumping well to canals ....22

20. Graph showing discharge from USGS 10335000 HUMBOLDT RV NR

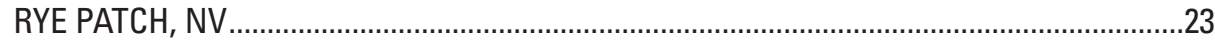

21. Graph showing drawdown of Wells $1,2,3,8$ and 10 through time................................23

22. Map of the location of Lovelock Valley aquifer test showing the pumping well and fifteen observation wells

23. Photograph showing pumping well discharging water at a rate of 6,038 gallons

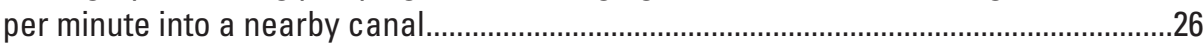

24. Graph showing 12-hour averaged drawdowns of Wells 8, 9, 11, 12, and 13

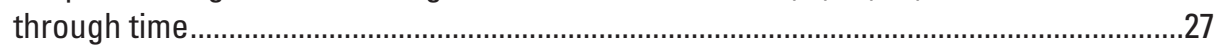

25. Grid discretization of the active model cells for both MWP1 and MWP2 models .........29

26. Simplified cross-section of hydrogeologic units used in the MODFLOW models, not drawn to scale

27. Map showing zonation of conceptual model layer 2 
28. Map showing pilot point distribution in layer 3

29. Graph showing simulated versus observed drawdown during multi-well pumping test \#1 (MWP1) for Well 1, located 1.2 miles from the pumping well.. .34

30. Graph showing simulated versus observed drawdown during multi-well pumping test \#1 (MWP1) for Well 2, located 1.5 miles from the pumping well.. .34

31. Graph showing simulated versus observed drawdown during multi-well pumping test \#1 (MWP1) for Well 3, located 1.2 miles from the pumping well... .35

32. Graph showing simulated versus observed drawdown during multi-well pumping test \#1 (MWP1) for Well 8, located 2.4 miles from the pumping well..

33. Graph showing simulated versus observed drawdown during multi-well pumping test \#1 (MWP1) for Well 10, located 5.0 miles from the pumping well..

34. Graph showing simulated versus observed drawdown during multi-well pumping test \#1 (MWP1) for Well 10, located 5.0 miles from the pumping well.

35. Graph showing simulated versus observed drawdown during multi-well pumping test \#2 (MWP2) for Well 3, located 6.0 miles from the pumping well..

36. Graph showing simulated versus observed drawdown during multi-well pumping test \#2 (MWP2) for Well 4, located 5.0 miles from the pumping well..

37. Graph showing simulated versus observed drawdown during multi-well pumping test \#2 (MWP2) for Well 6, located 4.8 miles from the pumping well

38. Graph showing simulated versus observed drawdown during multi-well pumping test \#2 (MWP2) for Well 7, located 4.8 miles from the pumping well

39. Graph showing simulated versus observed drawdown during multi-well pumping test \#2 (MWP2) for Well 8, located 2.6 miles from the pumping well

40. Graph showing simulated versus observed drawdown during multi-well pumping test \#2 (MWP2) for Well 9, located 1.0 miles from the pumping well..

41. Graph showing simulated versus observed drawdown during multi-well pumping test \#2 (MWP2) for Well 10.

42. Graph showing simulated versus observed drawdown during multi-well pumping test \#2 (MWP2) for Well 11, located 0.6 miles from the pumping well.

43. Graph showing simulated versus observed drawdown during multi-well pumping test \#2 (MWP2) for Well 12, located 0.6 miles from the pumping well..

44. Graph showing simulated versus observed drawdown during multi-well pumping test \#2 (MWP2) for Well 13, located 0.6 miles from the pumping well.

45. Graph showing simulated versus observed drawdown during multi-well pumping test \#2 (MWP2) for Well 14, located 5.1 miles from the pumping well.

46. Graph showing simulated versus observed drawdown during MWP2 for Well 15, located 9.6 miles from the pumping well ..

47. Graph showing simulated versus observed drawdown during MWP2 for Well 16, located 9.6 miles from the pumping well .....

48. Graph showing simulated versus observed drawdown during multi-well pumping test \#2 (MWP2) for Well 17, located 12.3 miles from the pumping well.

49. Map showing maximum drawdowns of various contour intervals are shown after the wells were shut off from multi-well pumping tests \#1 and \#2.

50. Map showing simulated transmissivity in the area of observed drawdown from multi-well pumping tests \#1 and \#2.

51. Map showing transmissivity values calculated from well log-derived specific conductivities for wells screened at depths of 51 feet or greater. 


\section{Tables}

1. Summary of the aquifer tests conducted in Lovelock Valley, Nevada, between March 8, 2017, and April 15, 2018.

2. Well data for 17 wells in Lovelock Valley, Nevada, used to estimate aquifer hydraulic conductivity.

3. Hydraulic conductivity and transmissivity estimates from the Bouwer and Rice (1976) analyses of slug-test data from Wells 6, 7, 13, 14, 15, and 16, in Lovelock Valley, Nevada.

4. Hydraulic conductivity and transmissivity estimates from the Bouwer and Rice (1976) analysis of slug-test data from Well 14 in Lovelock Valley, Nevada.....

5. Drawdowns estimated with water-level models for observation wells during multi-well pumping test \#1

6. Drawdowns estimated with water-level models for observation wells during multi-well pumping test \#2

7. Weighted RMS error values for all pumping-observation well pairs in Lovelock Valley, Nevada......

8. Estimated transmissivities of selected groupings of hydrostratigraphic units around locations of pumping wells in Lovelock Valley, Nevada.

\section{Conversion Factors}

U.S. customary units to International System of Units

\begin{tabular}{lcl}
\hline \multicolumn{1}{c}{ Multiply } & By & \multicolumn{1}{c}{ To obtain } \\
\hline inch (in.) & Length & \\
foot (ft) & 2.54 & centimeter $(\mathrm{cm})$ \\
mile (mi) & 0.3048 & meter $(\mathrm{m})$ \\
\hline & 1.609 & kilometer $(\mathrm{km})$ \\
\hline square foot $\left(\mathrm{ft}^{2}\right)$ & Area & \\
\hline & 0.09290 & square meter $\left(\mathrm{m}^{2}\right)$ \\
\hline gallon $(\mathrm{gal})$ & Volume & \\
cubic foot $\left(\mathrm{ft}^{3}\right)$ & 3.785 & liter $(\mathrm{L})$ \\
& 0.02832 & cubic meter $\left(\mathrm{m}^{3}\right)$ \\
\hline foot per day $(\mathrm{ft} / \mathrm{d})$ & Flow rate & \\
cubic foot per second $\left(\mathrm{ft}^{3} / \mathrm{s}\right)$ & 0.3048 & meter per day $(\mathrm{m} / \mathrm{d})$ \\
gallon per minute $(\mathrm{gal} / \mathrm{min})$ & 0.02832 & cubic meter per second $\left(\mathrm{m}^{3} / \mathrm{s}\right)$ \\
\hline & 0.06309 & liter per second $(\mathrm{L} / \mathrm{s})$ \\
\hline foot squared per day $\left(\mathrm{ft}^{2} / \mathrm{d}\right)$ & Transmissivity & \\
\hline
\end{tabular}




\section{Datum}

Vertical coordinate information is referenced to the North American Vertical Datum of 1988 (NAVD 88).

Horizontal coordinate information is referenced to the North American Datum of 1983 (NAD 83).

Altitude, as used in this report, refers to distance above the vertical datum.

\section{Abbreviations}

$\begin{array}{ll}\text { HA } & \text { hydrographic area } \\ \text { LSD } & \text { land surface datum } \\ \text { MP } & \text { measuring point } \\ \text { MWP1 } & \text { multi-well pumping test \#1 } \\ \text { MWP2 } & \text { multi-well pumping test \#2 } \\ \text { PEST } & \text { Model-Independent Parameter Estimation and Uncertainty Analysis } \\ \text { PST } & \text { Pacific standard time } \\ \text { PDT } & \text { Pacific daylight time } \\ \text { RMS } & \text { root mean square } \\ \text { USGS } & \text { U.S. Geological Survey }\end{array}$




\title{
Analysis of Aquifer Framework and Hydraulic Properties of Lovelock Valley, Lovelock, Nevada
}

\author{
By Cara Nadler
}

\section{Summary}

Multiple aquifer tests were conducted in Lovelock, Nevada, to determine hydraulic conductivity and storage properties to be used with the numerical groundwater flow model of the lower Humboldt River Basin while accounting for the influence of surface features with a modeling component (table 1). The numerical model will ultimately provide the Nevada Division of Water Resources (NDWR) with information regarding the impacts of groundwater pumping on the Humboldt River, allowing the Nevada State Engineer to make informed decisions in the conjunctive management of the State's groundwater and surface water resources. Seven slug tests, one single-well pumping test, and two multi-well pumping tests were conducted to evaluate properties of shallow Lahontan clays and silts; shallow fluvial deposits; and coarser, water-bearing deposits of the younger alluvium (table 1). Aquifer tests were conducted between March 2017 and April 2018. Results indicate aquifers in the Lovelock Valley have transmissivity ranging between 0.0001 and 95,000 feet squared per day ( $\mathrm{ft}^{2} /$ day). The results of these tests provide constraints on hydraulic properties for a numerical groundwater flow model being developed for a capture study in the lower Humboldt River Basin.

\section{Hydrogeology and Aquifers}

Lovelock Valley, Nevada, (fig. 1) is characterized by three primary hydrogeologic units: consolidated rock (late Paleozoic to Cenozoic), water-bearing older alluvium (late Tertiary and Quaternary), and younger alluvium (Pleistocene; Everett and Rush, 1965). The low-permeability consolidated rock surrounds and underlies the valley. The older alluvium is unconsolidated to poorly consolidated and consists of gravel, sand, silt, and clay. The older alluvium lines the mountains and underlies the younger alluvium away from the mountain margins. The older alluvium is not investigated in this study. The younger alluvium contains the primary water-bearing sediments in Lovelock Valley and is the focus of this study. The younger alluvium is composed of gravel, sand, silt, and clay sourced as colluvium from the surrounding mountains; fluvial sediments of the meandering and braided Humboldt River paleochannel; and lacustrine sediments from Pleistocene Lake Lahontan. Lake Lahontan clays and silts constitute the upper part of the younger alluvium and are reported to blanket the basin with a thickness of 20-35 feet (ft; Everett and Rush, 1965). Well logs in Lovelock Valley indicate this clay and silt may be as thick as $50 \mathrm{ft}$ in places. Coarser material underlying the clay layer of the younger alluvium comprises the primary aquifer and is up to $1,365 \mathrm{ft}$ thick, though most wells penetrated less than $400 \mathrm{ft}$ of the younger alluvium. This report will investigate and describe hydraulic properties of three aquifers of the younger alluvium: Lahontan clays and silts, fluvial deposits, and coarser alluvium. The lateral extents of the three aquifers were determined by modifying the surface hydrogeology by Maurer and others (2004; figs. 2-4).

Table 1. Summary of the aquifer tests conducted in Lovelock Valley, Nevada, between March 8, 2017, and April 15, 2018.

\begin{tabular}{llllc}
\hline Test well numbers & \multicolumn{1}{c}{ Test type } & \multicolumn{1}{c}{ Test dates } & \multicolumn{1}{c}{$\begin{array}{c}\text { Aquifer tested } \\
\text { Transmissivity } \\
\left(\mathbf{f t}^{2} / \mathbf{d}\right)\end{array}$} \\
\hline $6,7,12,13,15,16$ & Injection slug tests & January 9, 2018-April 15, 2018 & $\begin{array}{c}\text { Lahontan clays and silts } \\
\text { Coarser alluvium }\end{array}$ \\
& Injection slug test & August 10, 2017 & Coarser alluvium \\
3 & Single-well pumping test & August 9, 2017 & Lahontan clays and silts, fluvial & $0.0001-95,000$ \\
4 & Multi-well pumping test & March 8, 2017-March 12, 2017 & deposits, and coarser alluvium \\
10 & Multi-well pumping test & November 28, 2017-December 4, 2017 & $\begin{array}{c}\text { Lahontan clays and silts, fluvial } \\
\text { deposits, and coarser alluvium }\end{array}$ \\
\hline
\end{tabular}




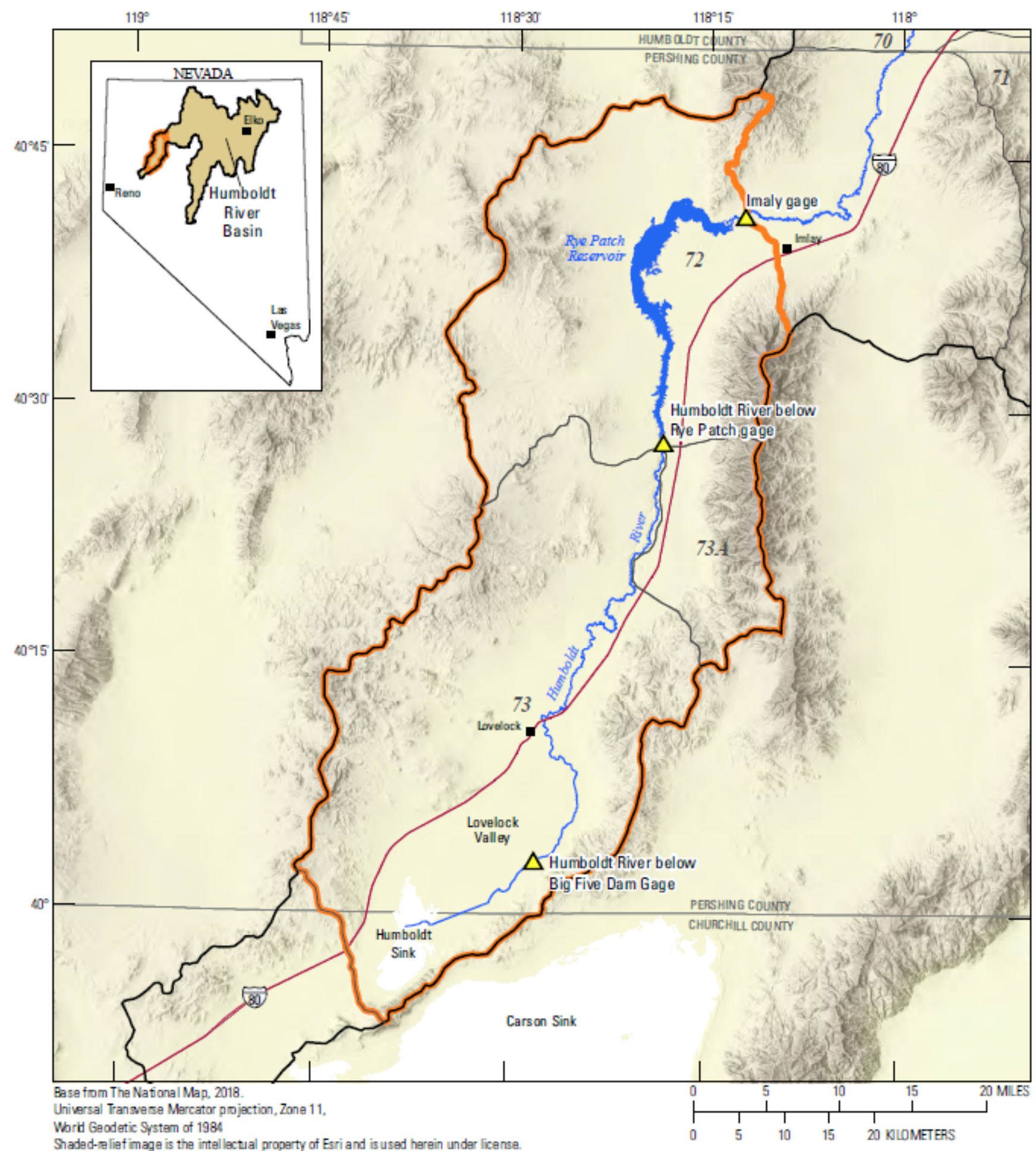

Shadad-aliafimage is the intel lectual property of Esri and is used herein under license.

Copyight $\oplus 2018$ Esri and its licensors. All rights reserved.

EXPLANATION

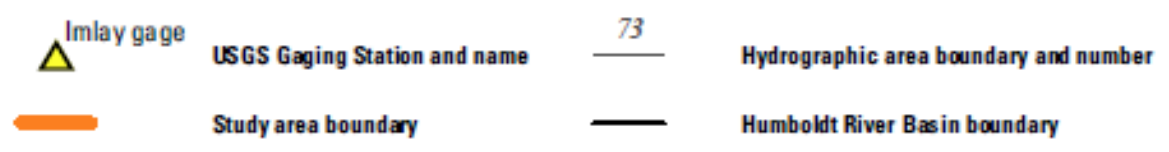

Figure 1. The lower Humboldt River Basin study area including Lovelock Valley, Nevada. 


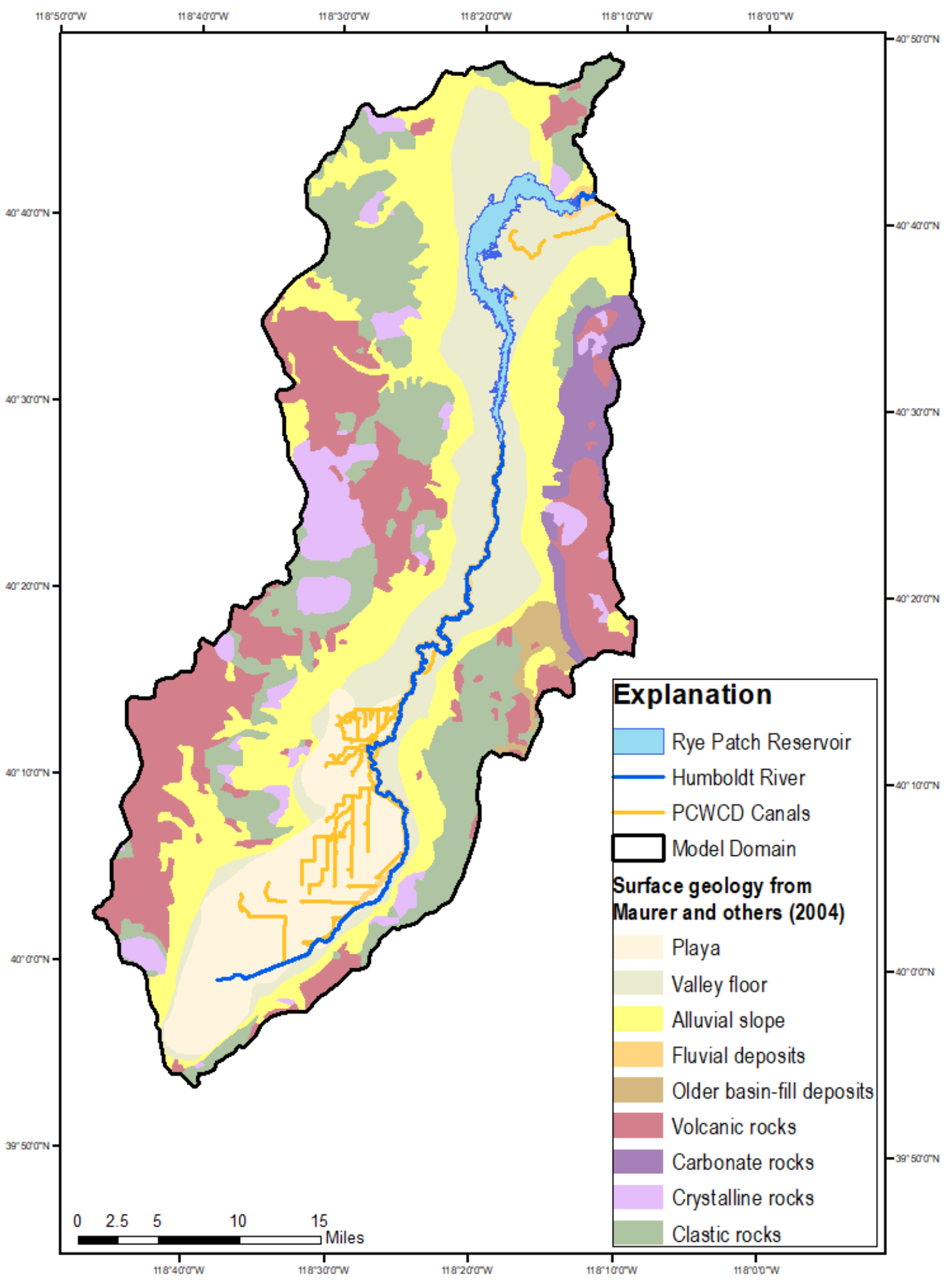

Figure 2. Surface geology of the lower Humboldt River Basin, Nevada (modified for simplicity from Maurer and others, 2004). The surface geologic units were further modified to represent the three hydrogeologic units described by Everett and Rush (1965). The Pershing County Water Conservation District (PCWCD) canals are shown in orange. 


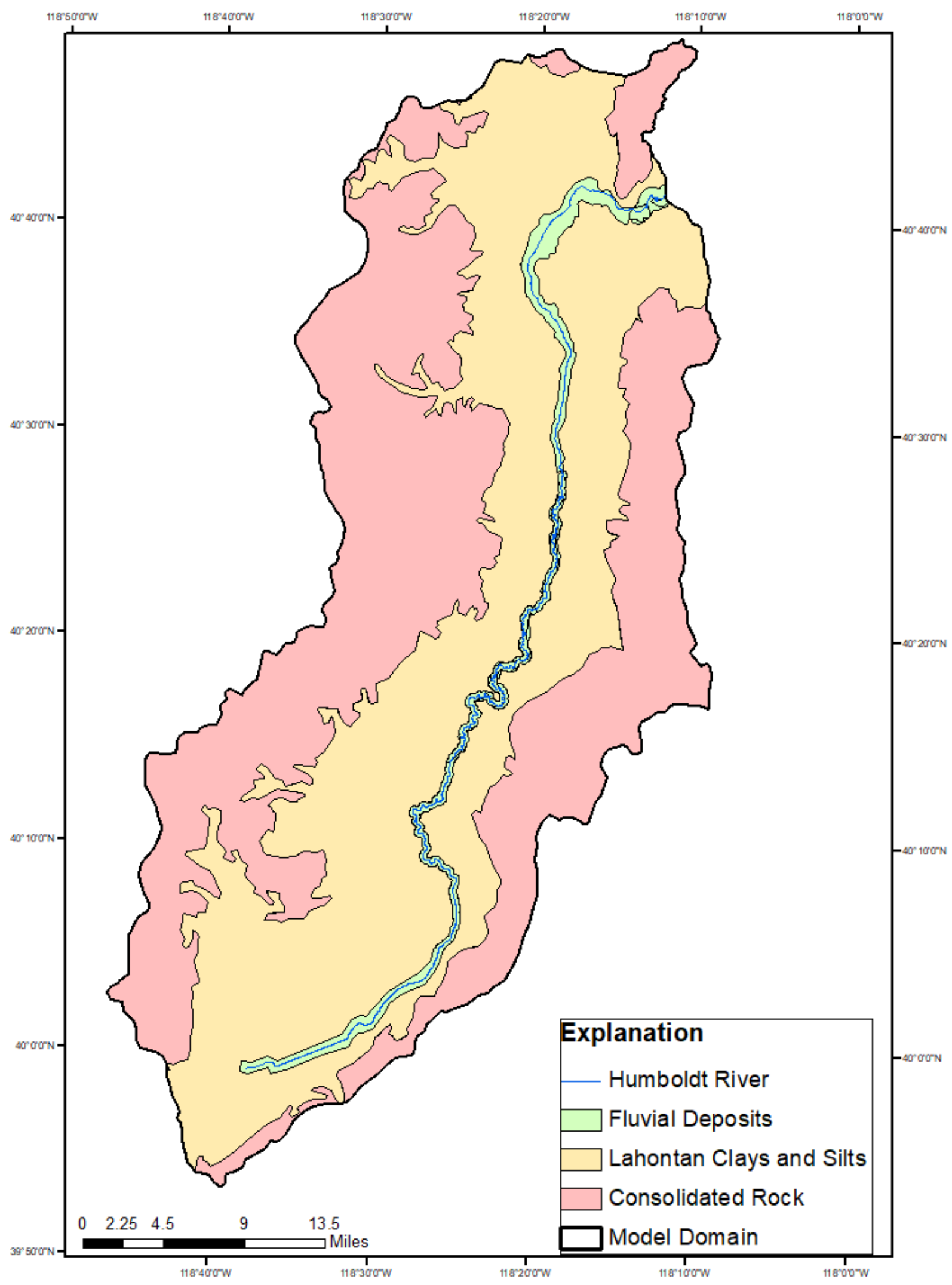

Figure 3. Lateral extent of two near-surface aquifers (fluvial deposits and Lahontan clays and silts) derived from Maurer and others (2004) in the lower Humboldt River Basin model domain of northern Nevada. 


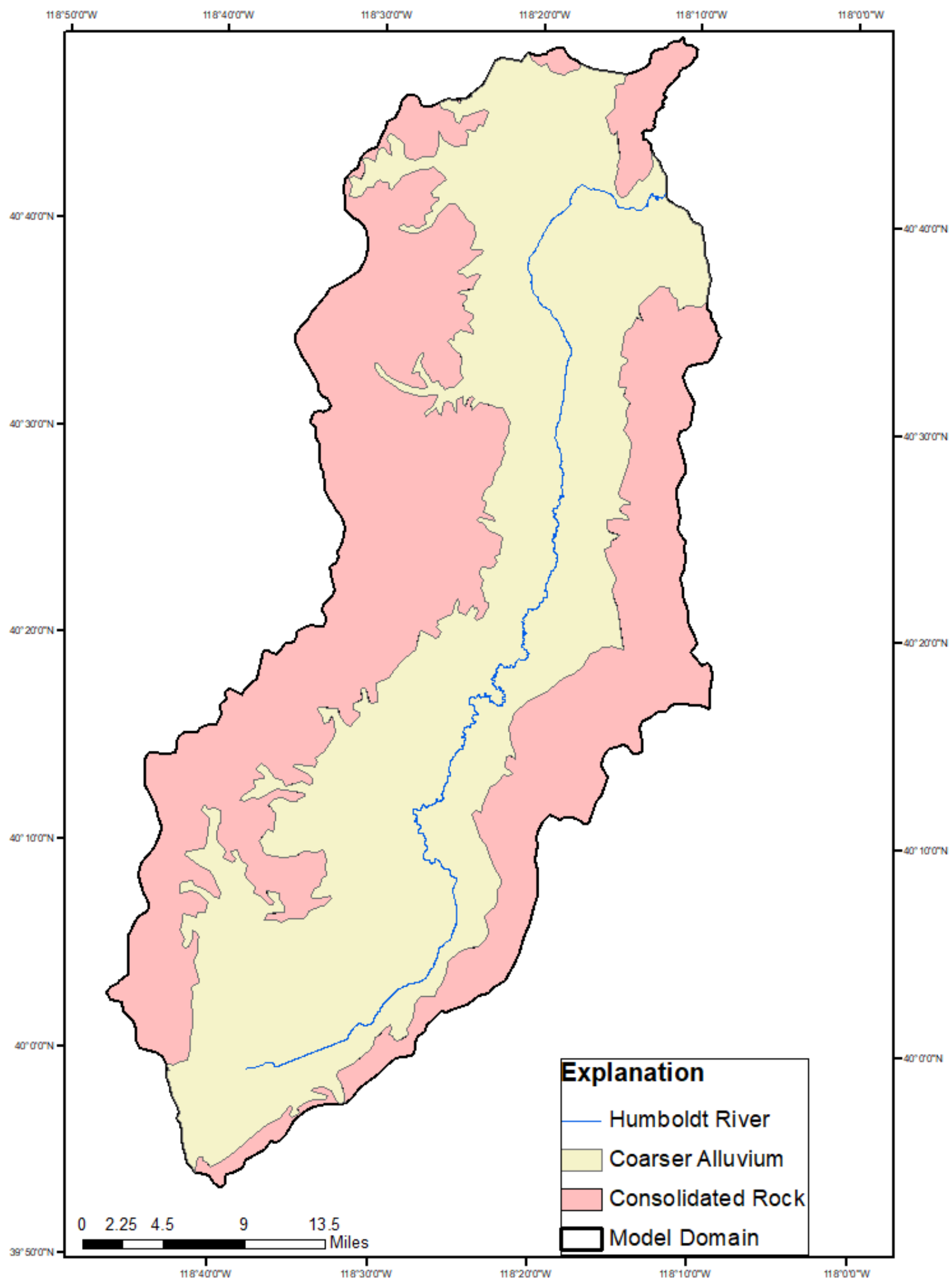

Figure 4. Lateral extent of the deeper water-bearing aquifer (coarser alluvium) derived from Maurer and others (2004) in the lower Humboldt River Basin model domain of northern Nevada. 
Surface geology defined by Maurer and others (2004) includes 12 units categorized by rock type and age for Lovelock Valley. Surface geologic units were combined based on rock type, removing the age component, which resulted in 9 units (fig. 2). The surface geologic units were further modified to represent the three hydrogeologic units described by Everett and Rush (1965). Older basin-fill deposits, volcanic rocks, carbonate rocks, crystalline rocks, and clastic rocks were combined to represent the consolidated rock unit (figs. 3, 4). The younger alluvium is composed of the remaining units, which were further refined to represent the three aquifers of the younger alluvium - Lahontan clays and silts, fluvial deposits, and coarser alluvium. Playa, valley floor, and alluvial slope deposits were combined to represent the Lahontan clays and silts (figs. 2,3). The fluvial deposits were further modified from the original aerial extent by Maurer and others
(2004) to represent the fluvial aquifer to connect and extend the fluvial zone (fig. 3). The fluvial deposits described by Maurer and others (2004) are spatially limited and exclude the likely existence of fluvial sediments outside the narrow river corridor. The Lahontan clays and silts and the fluvial deposits compose the two near-surface aquifers that are found above the coarser alluvium aquifer. Playa, valley floor, alluvial slope, and fluvial deposits were combined at depth to represent the coarser alluvium aquifer (figs. 2, 4). Seventeen wells with varied well-screen intervals were used to verify and further refine the characterizations of the three aquifers of the younger alluvium (fig. 5, table 2). The Lahontan clays and silts include relatively thick sand layers in many areas in Lovelock Valley, and this type of fine and coarse layering and field observations suggest the Lahontan clays and silts compose a leaky confined aquifer. 


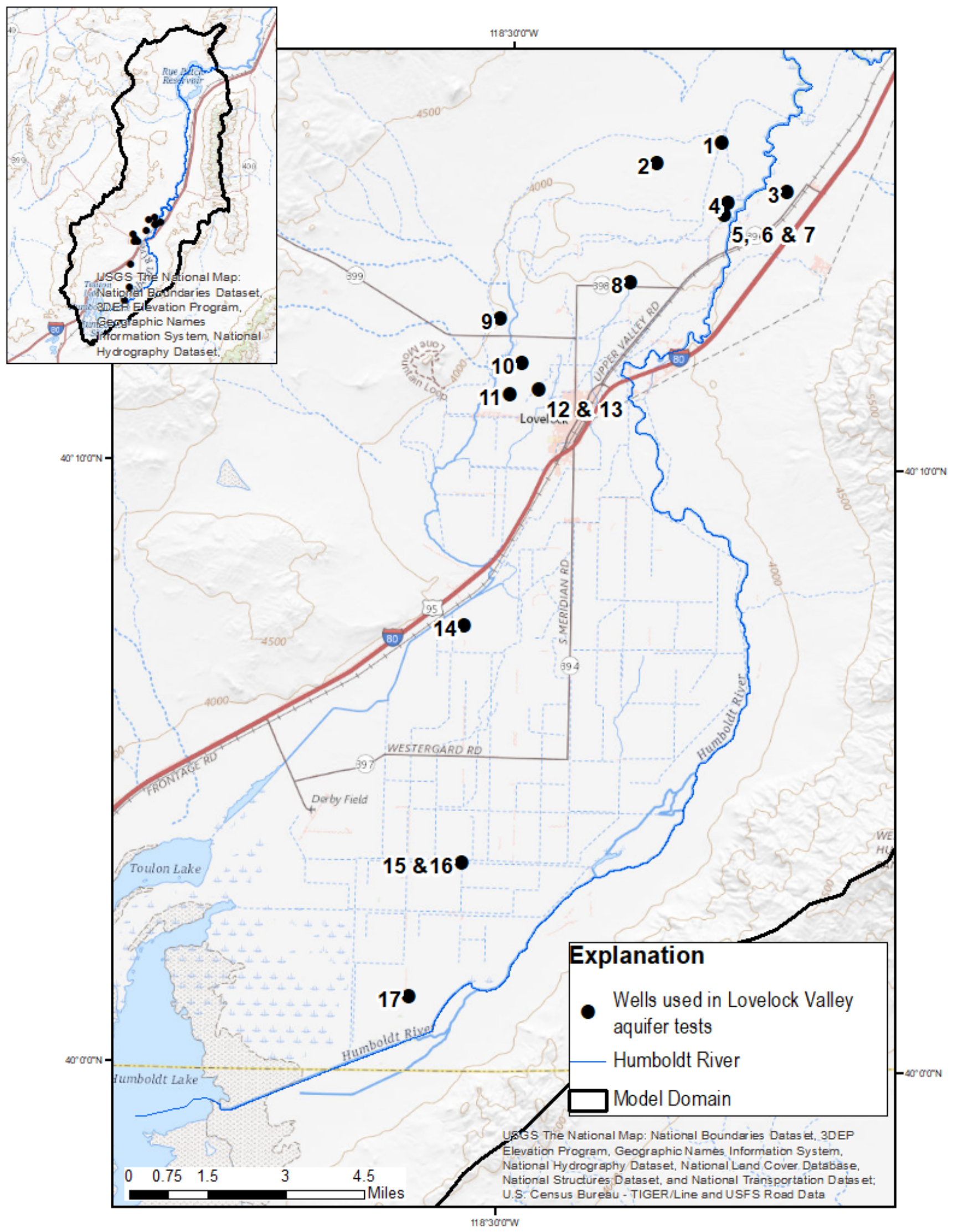

Figure 5. Wells used in the Lovelock Valley, Nevada, aquifer tests. 
Table 2. Well data for 17 wells in Lovelock Valley, Nevada, used to estimate aquifer hydraulic conductivity.

[Latitude and longitude are given in decimal degrees NAD 83; altitude is given as land surface altitude. Although the short names of each well are not used in this report, they are used in the associated data files. Abbreviations: ft, foot; ID, identification; in., inch; MWP1, multi-well pumping test \#1; MWP2, multi-well pumping test \#2]

\begin{tabular}{|c|c|c|c|c|c|c|c|c|c|c|}
\hline USGS Site ID & $\begin{array}{l}\text { Short } \\
\text { name }\end{array}$ & $\begin{array}{c}\text { Map/ } \\
\text { well } \\
\text { name }\end{array}$ & $\begin{array}{c}\text { Altitude } \\
\text { (ft, NAVD 88) }\end{array}$ & $\begin{array}{l}\text { Screened interval } \\
\text { (ft below land } \\
\text { surface) }\end{array}$ & $\begin{array}{l}\text { Casing outer } \\
\text { diameter } \\
\text { (in.) }\end{array}$ & Primary aquifer & Latitude & Longitude & $\begin{array}{l}\text { Distance from } \\
\text { MWP1 pumping } \\
\text { well } 4 \\
\text { (miles) }\end{array}$ & $\begin{array}{l}\text { Distance from } \\
\text { MWP2 pumping } \\
\text { well } 10 \\
\text { (miles) }\end{array}$ \\
\hline 401525118252901 & FETH & 1 & 4,023 & $160-200$ & 6.7 & Coarser alluvium & 40.257007 & -118.424608 & 1.2 & 5.7 \\
\hline 401504118265301 & WAGT & 2 & 4,005 & $226-234$ & 10 & Coarser alluvium & 40.251013 & -118.447954 & 1.5 & 4.6 \\
\hline 401437118240301 & AIRP & 3 & 4,029 & $95-184$ & 12 & Coarser alluvium & 40.243653 & -118.400819 & 1.2 & 6.0 \\
\hline 401426118252001 & MOIR & 4 & 4,009 & $\begin{array}{l}160-320 \\
360-520\end{array}$ & 18 & Coarser alluvium & 40.240365 & -118.422232 & 0.0 & 5.0 \\
\hline 401413118252401 & MSTOK & 5 & 4,004 & NA & NA & Lahontan clays and silts & 40.236820 & -118.423274 & 0.3 & NA \\
\hline 401409118252102 & MS & 6 & 4,010 & $20-25$ & 2.4 & Lahontan clays and silts & 40.235945 & -118.422508 & NA & 4.8 \\
\hline 401409118252101 & MD & 7 & 4,010 & $42.75-52.75$ & 2.4 & Lahontan clays and silts & 40.235945 & -118.422508 & NA & 4.8 \\
\hline 401304118272501 & NDOA & 8 & 3,996 & $14.5-24.5$ & 2 & Lahontan clays and silts & 40.217713 & -118.457019 & 2.4 & 2.6 \\
\hline 401226118301401 & LEID & 9 & 4,001 & NA & NA & Coarser alluvium & 40.207264 & -118.503644 & NA & 1.0 \\
\hline 401142118294001 & BING & 10 & 3,986 & $100-351$ & $18 \& 26$ & Coarser alluvium & 40.194910 & -118.495320 & 5.0 & 0 \\
\hline 401110118300001 & WWBN & 11 & 3,981 & $200-387$ & 14 & Coarser alluvium & 40.186189 & -118.499881 & NA & 0.6 \\
\hline 401115118292002 & BS & 12 & 3,986 & $16.3-21.3$ & 2.4 & Lahontan clays and silts & 40.187599 & -118.489156 & NA & 0.6 \\
\hline 401115118292001 & $\mathrm{BD}$ & 13 & 3,986 & $45-55$ & 2.4 & Lahontan clays and silts & 40.187599 & -118.489156 & NA & 0.6 \\
\hline 400719118305301 & PINN & 14 & 3,948 & $158-178$ & 10.7 & Coarser alluvium & 40.121959 & -118.514688 & NA & 5.1 \\
\hline 400323118305002 & WS & 15 & 3,908 & $22-25$ & 2.4 & Lahontan clays and silts & 40.056391 & -118.514098 & NA & 9.6 \\
\hline 400323118305001 & WD & 16 & 3,908 & $45-55$ & 2.4 & Lahontan clays and silts & 40.056391 & -118.514098 & NA & 9.6 \\
\hline 400108118315701 & TWEL & 17 & 3,902 & NA & NA & Lahontan clays and silts & 40.019006 & -118.532428 & 16.4 & 12.3 \\
\hline
\end{tabular}




\section{Well Data}

Seventeen wells were used for the ten aquifer tests conducted in Lovelock Valley, Nevada, between March 2017 and April 2018 (fig. 1, table 1). Wells 1, 2, and 3 are domestic wells, of which only Well 1 is actively used at the time of this report. Wells 4, 9, 10, and 11 are agricultural wells. Wells 5 and 17 are agricultural stock wells. Wells $6,7,8,12,13,15$, and 16 are shallow observation wells. Well 14 is an industrial commercial well.

\section{Transmissivities of the Lahontan Clays and Silts Evaluated from Slug Tests}

The hydraulic conductivities of fine alluvial sediments that form the Lahontan clays and silts were estimated from injection slug testing of six 2-inch diameter monitoring wells in Lovelock Valley, Nevada, hydrographic area (HA) 073 (fig. 6). The tests were conducted between January 9, 2018, and April 15, 2018.

\section{Field Procedures}

Wells $6,7,12,13,15$, and 16 were selected to estimate transmissivity of the shallow Lahontan clays and silts in Lovelock Valley (table 2). Well 12 is $25 \mathrm{ft}$ deep and is screened in sandy clay loam from 16.3 to $21.3 \mathrm{ft}$. Well 13 is $55 \mathrm{ft}$ deep and is screened in silty loam from 45 to $55 \mathrm{ft}$. Well 6 is $25 \mathrm{ft}$ deep and is screened in silty loam from 20 to $25 \mathrm{ft}$. Well 7 is $55 \mathrm{ft}$ deep and is screened in silty loam from 42.75 to $52.75 \mathrm{ft}$. Well 15 is $25 \mathrm{ft}$ deep and is screened in mud slurry from 22 to $25 \mathrm{ft}$. Well 16 is $55 \mathrm{ft}$ deep and is screened in silty loam from 45 to $55 \mathrm{ft}$. These six wells are all constructed of 2-inch diameter casing set in 6-inch diameter holes. The open interval of all wells consists of factory-cut slot perforations.

Each well was instrumented with a pressure transducer to record water-level rise and fall (recovery to static conditions) at various intervals. Depth to water was measured prior to the start of the tests and repeated during the tests to ensure accuracy of transducer recorded water-level changes.

A 0.56-gallon PVC slug was rapidly lowered below the water level in each well, consequently raising the water level and left in place until the water level recovered. Next, the slug was rapidly pulled out of the water column, consequently lowering the water level in the well until the water level recovered. This process was repeated 1-9 times for each test.

\section{Analysis}

The method of Bouwer and Rice (1976) was used with coded Excel spreadsheets (Halford and Kuniansky, 2002) to analyze the water-level recovery data and estimate a hydraulic conductivity of the nearby aquifer material for each of the six wells (figs. 7-12). Early time data, which is more log-linear, was fit using the Bouwer and Rice (1976) method as suggested in the method documentation. The transmissivity of the Lahontan clays and silts, calculated as the product of the hydraulic conductivity and effective aquifer thickness (assumed to equal the well-screen length), ranges between $2 \mathrm{ft}^{2} /$ day and $55 \mathrm{ft}^{2} /$ day, with a potentially outlying value of $350 \mathrm{ft}^{2} /$ day that may not reflect the true formation transmissivity (table 3 ). Because the slug volume and well diameter were identical for each slug test, initial water-level perturbations in each well were nearly identical; however, the recovery period for each well varied from approximately 20 seconds to approximately 40 minutes, reflecting variations in transmissivity between well locations.

The wells used to analyze the younger alluvium finer sediments were not completed with gravel or sand packs around the screen openings. During well installations, each of the six holes collapsed before a gravel pack could be added around the screened interval. The lack of gravel completion may have resulted in small cavities surrounding the well screen, which could account for the large apparent transmissivity value estimated for Well 7. The logarithmic displacement over time of Well 7 (fig. 8B) has two straightline segments, which is indicative of water draining rapidly from the gravel pack before equalizing with the water in the well (Fetter, 1994). The second straight-line segment was used in the analysis because it more likely represents the surrounding aquifer (Fetter, 1994). Although there may be regions of higher transmissivity in the Lahontan clays and silts, the value estimated for Well 7 is somewhat greater than expected and cannot be entirely verified based on the small hydraulic stress applied during these slug tests. 


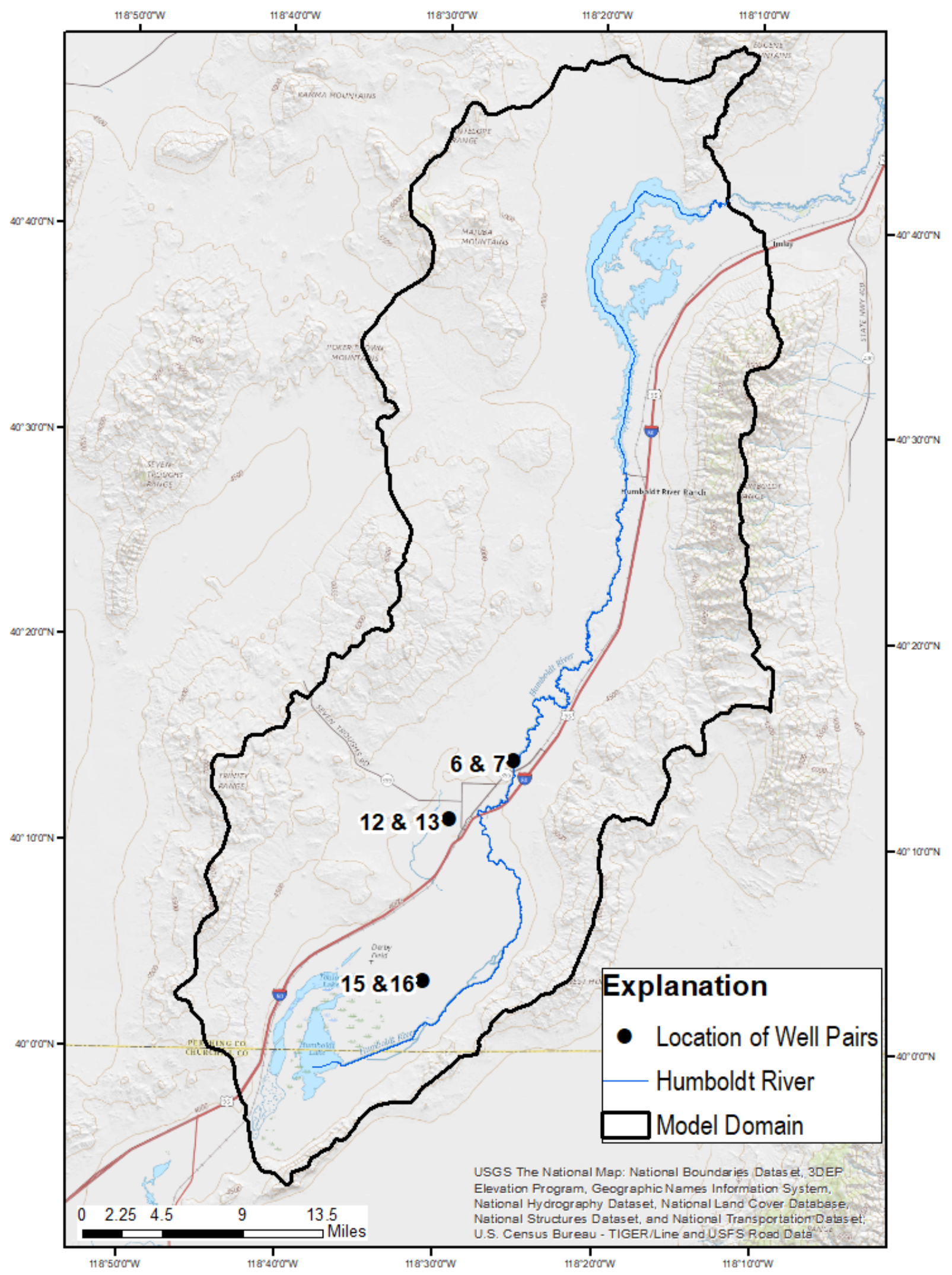

Figure 6. Locations of Wells 6, 7, 12,13, 15, 16, and the model domain for the forthcoming lower Humboldt River Basin capture study in northern Nevada. 

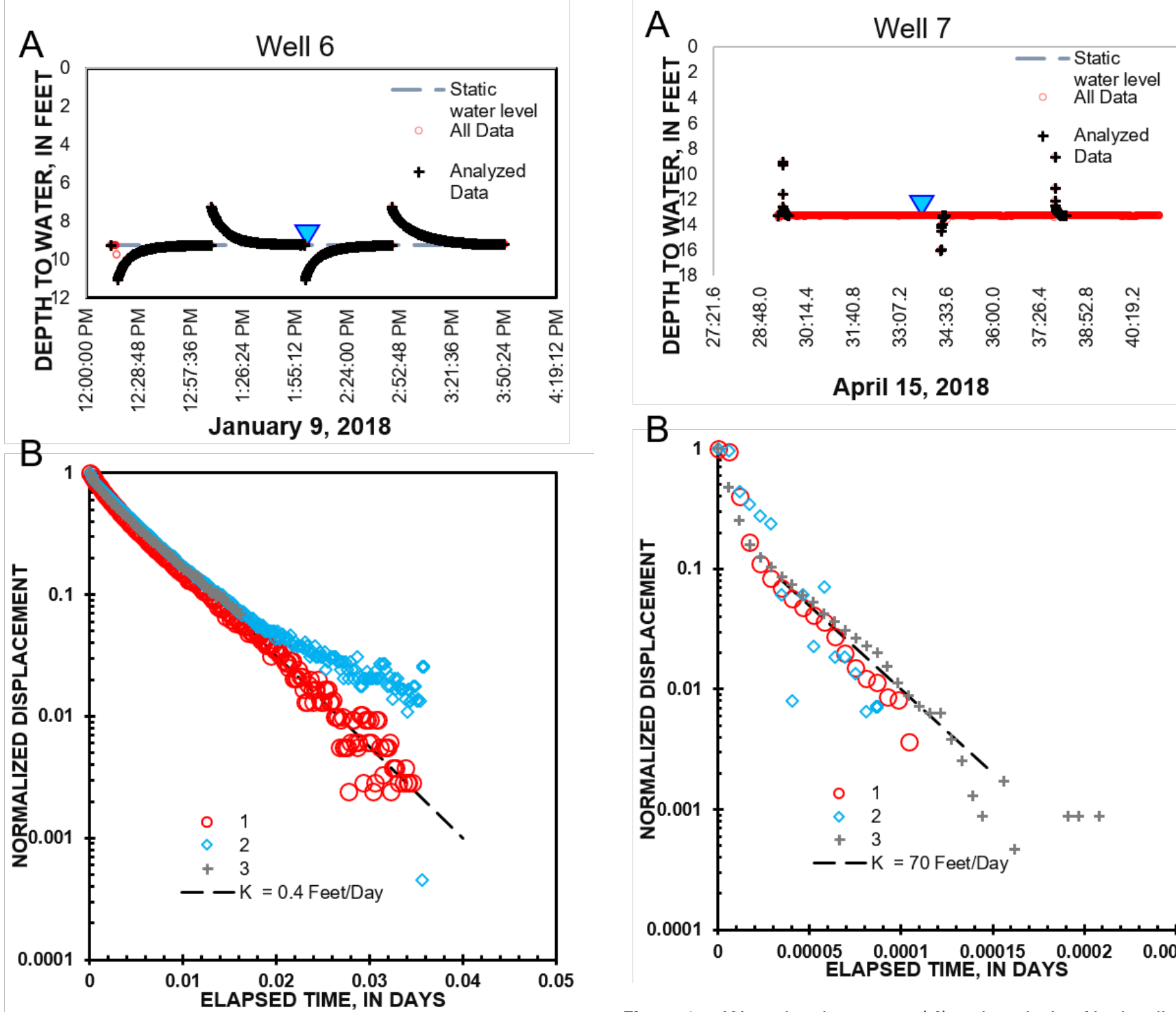

\section{April 15, 2018}

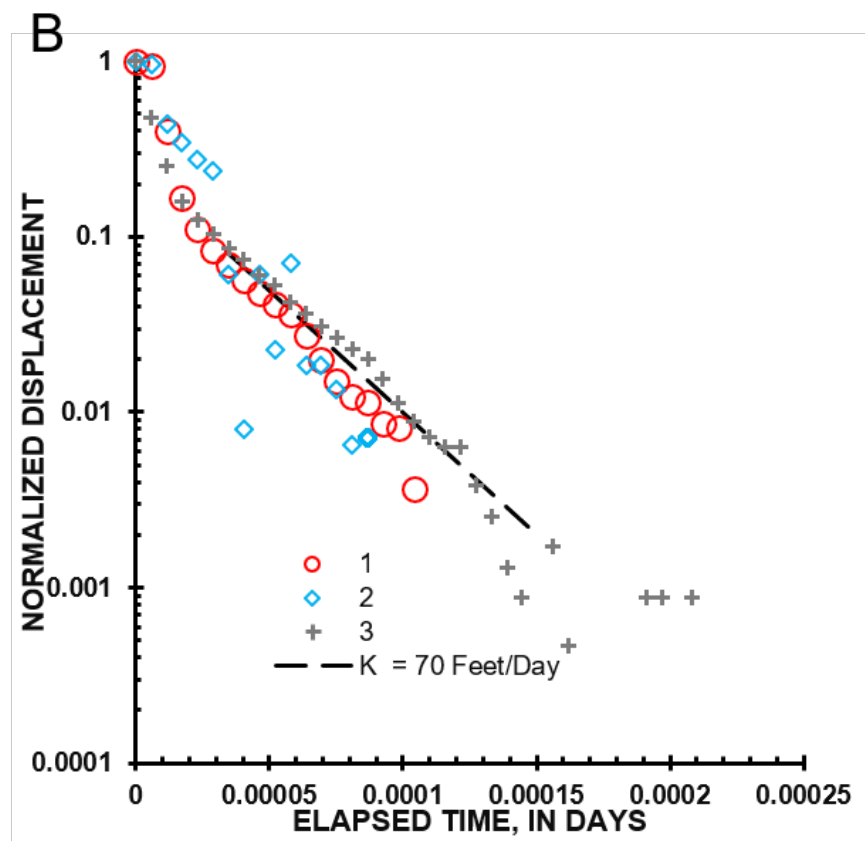

Figure 7. Water level response $(A)$ and analysis of hydraulic conductivity $(K)(B)$ of three injection slug tests (noted with red circles, blue diamonds, and green plus signs) conducted at Well 6

Figure 8. Water level response $(A)$ and analysis of hydraulic conductivity $(\mathrm{K})(B)$ of three injection slug tests (noted with red circles, blue diamonds, and green plus signs) conducted at Well 7 in Lovelock Valley, Nevada. 


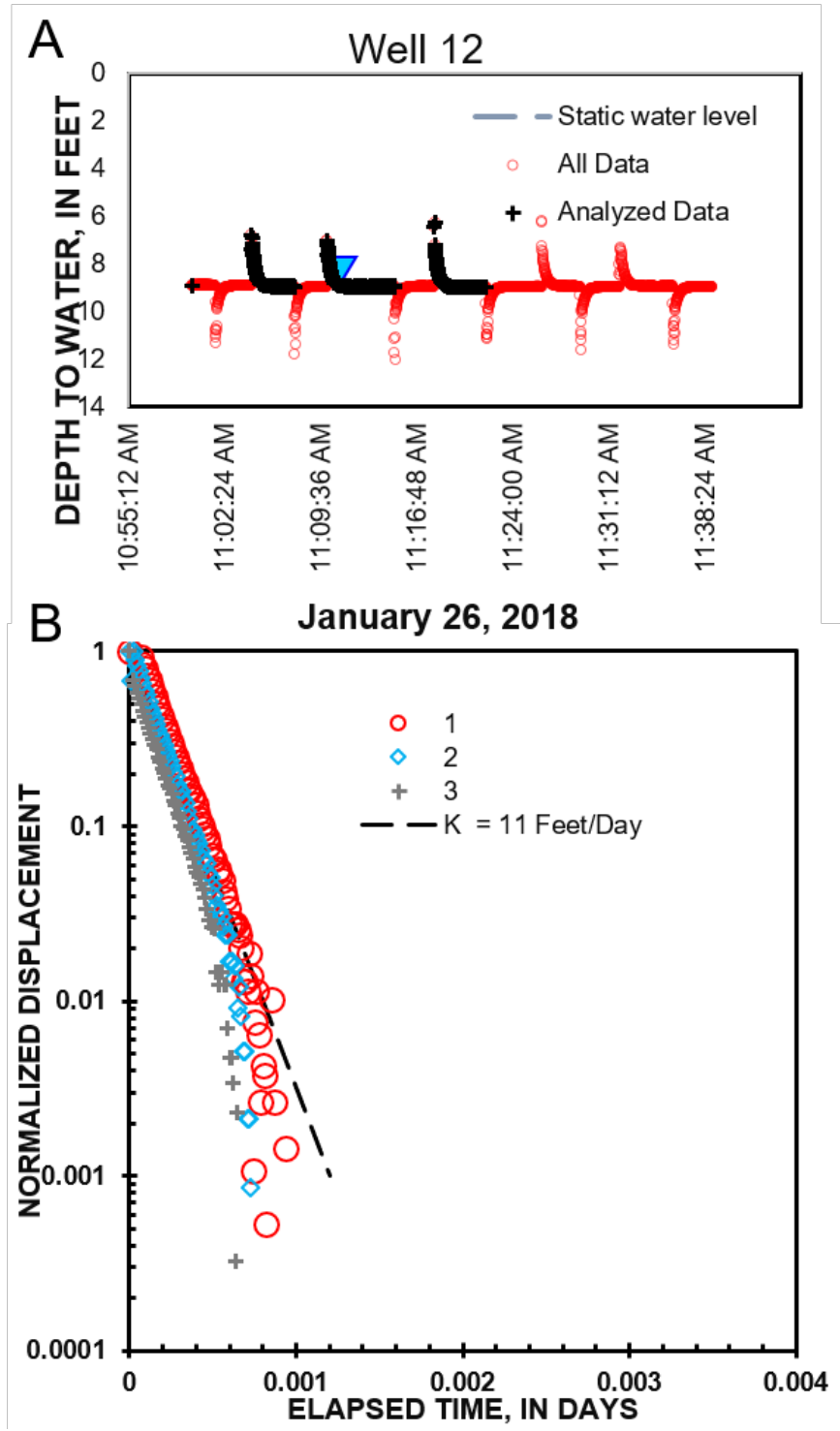

Figure 9. Water level response $(A)$ and analysis of hydraulic conductivity $(K)(B)$ of three injection slug tests (noted with red circles, blue diamonds, and green plus signs) conducted at Well 12 in Lovelock Valley, Nevada.
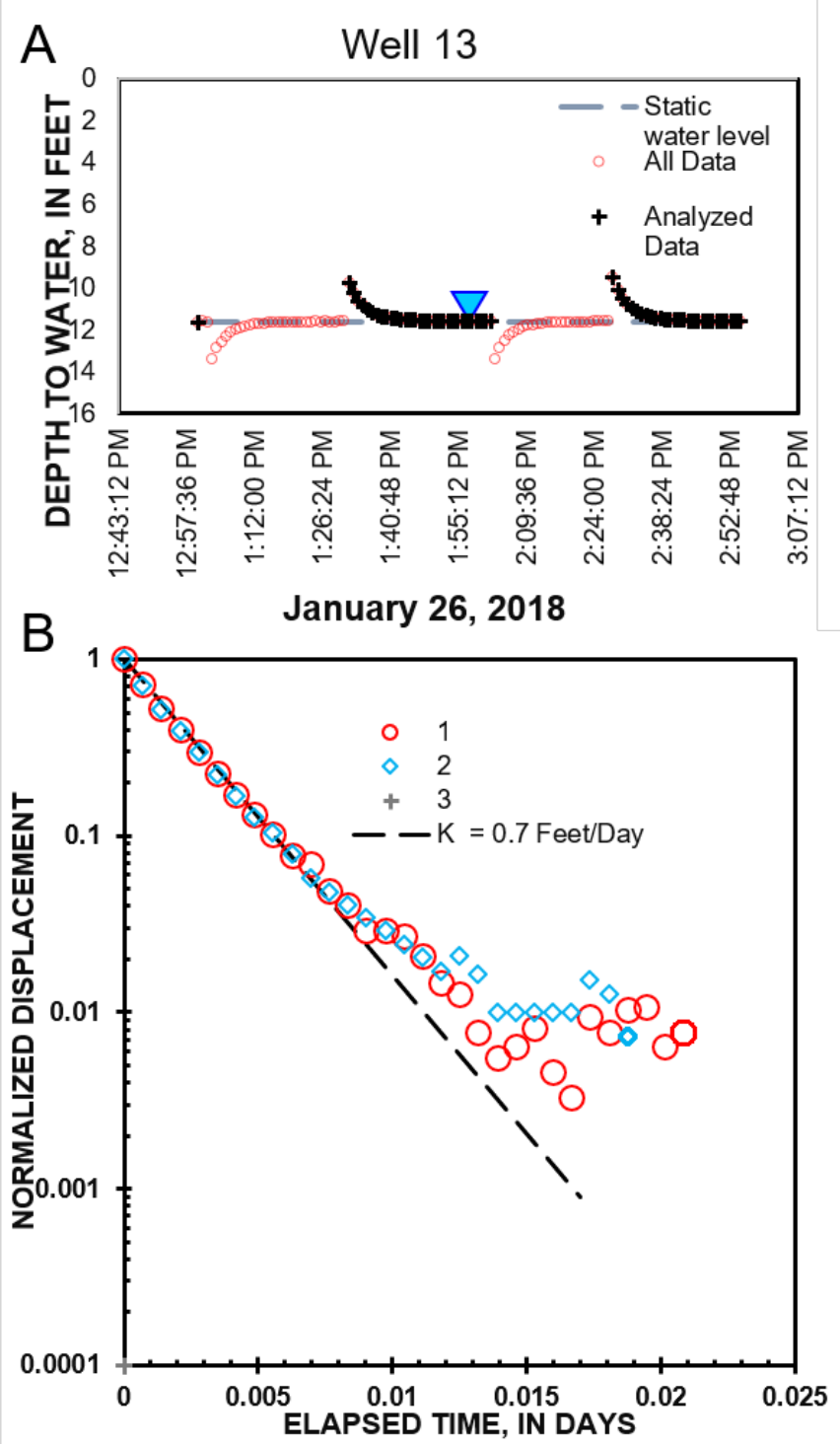

Figure 10. Water level response $(A)$ and analysis of hydraulic conductivity $(K)(B)$ of two injection slug tests (noted with red circles and blue diamonds) conducted at Well 13 in Lovelock Valley, Nevada. 


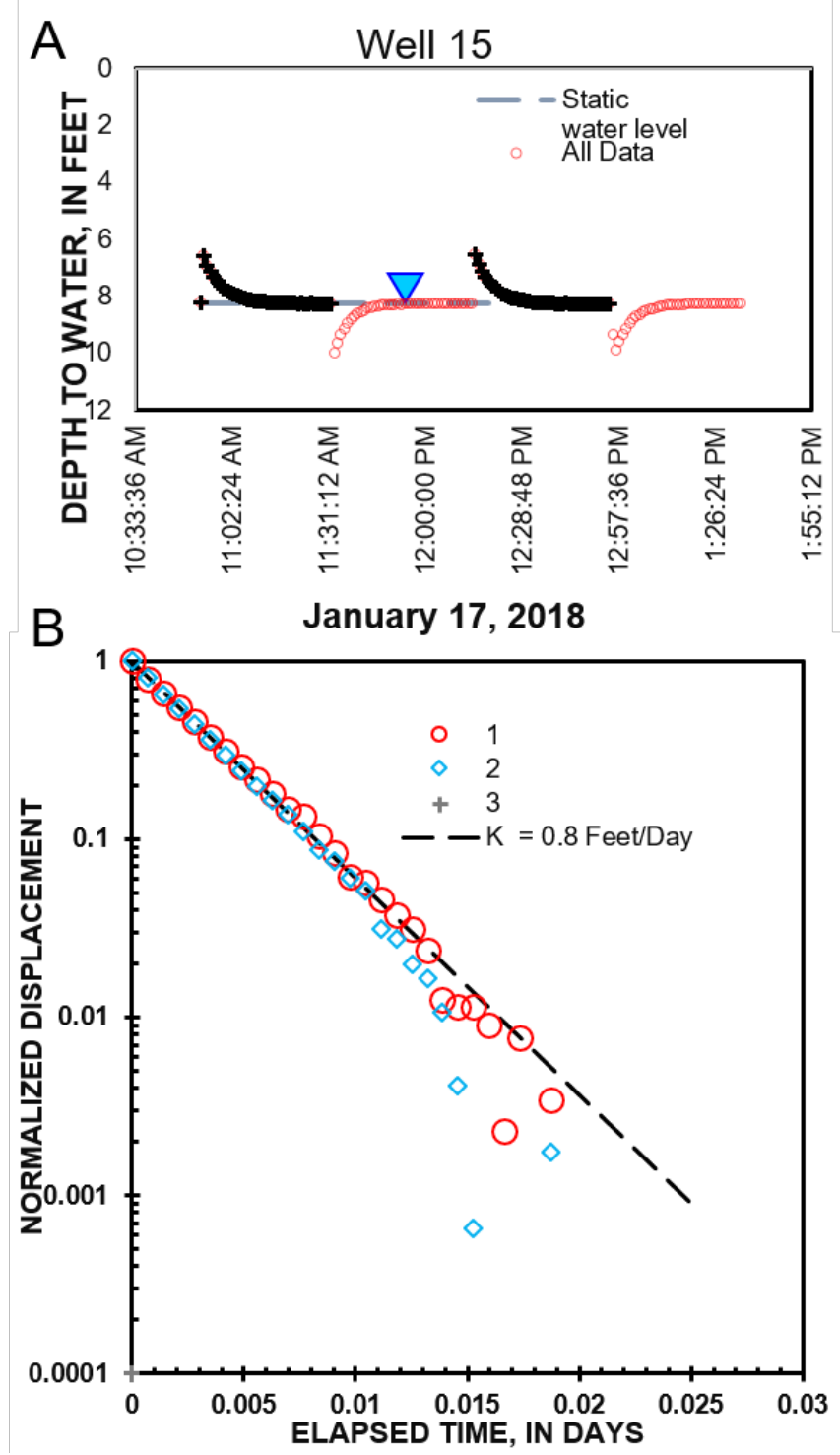

Figure 11. Water level response $(A)$ and analysis of hydraulic conductivity $(\mathrm{K})(B)$ of two injection slug tests (noted with red circles and blue diamonds) conducted at Well 15 in Lovelock Valley, Nevada.
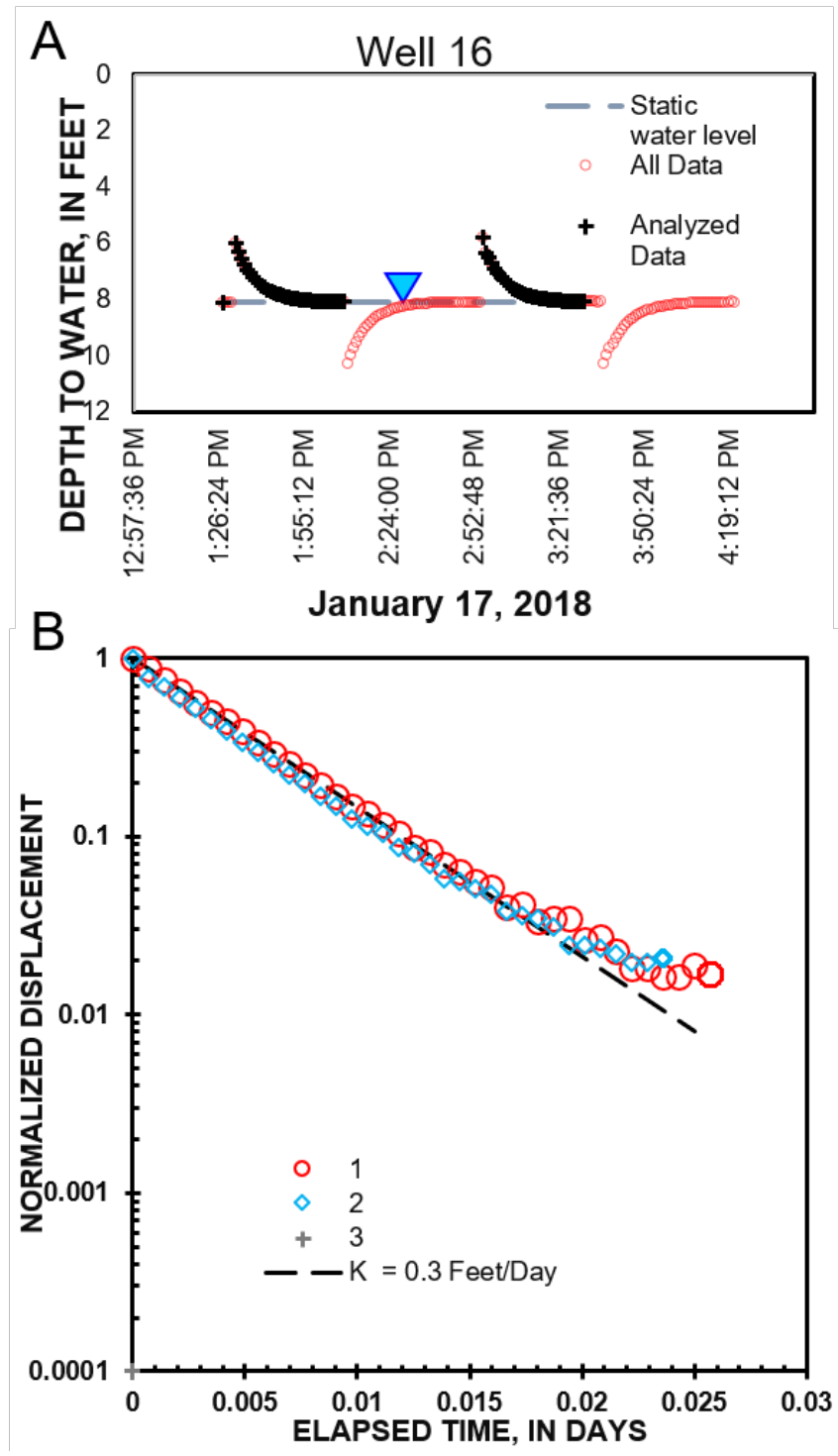

Figure 12. Water level response $(A)$ and analysis of hydraulic conductivity $(K)(B)$ of two injection slug tests (noted with red circles and blue diamonds) conducted at Well 16 in Lovelock Valley, Nevada. 
Table 3. Hydraulic conductivity and transmissivity estimates from the Bouwer and Rice (1976) analyses of slug-test data from Wells 6, 7, 13, 14, 15, and 16 in Lovelock Valley, Nevada.

[ft, foot; $\mathrm{ft} / \mathrm{d}$, foot per day; $\mathrm{ft}^{2} / \mathrm{d}$, foot squared per day]

\begin{tabular}{ccccc}
\hline Well & $\begin{array}{c}\text { Aquifer } \\
\text { material }\end{array}$ & $\begin{array}{c}\text { Effective } \\
\text { thickness } \\
\text { (ft) }\end{array}$ & $\begin{array}{c}\text { Hydraulic } \\
\text { conductivity } \\
\text { (ft/d) }\end{array}$ & $\begin{array}{c}\text { Transmissivity } \\
\left(\mathbf{f t}^{2} / \mathbf{d}\right)\end{array}$ \\
\hline 6 & $\begin{array}{c}\text { Lahontan clays } \\
\text { and silts }\end{array}$ & 5 & 0.4 & 2 \\
$7 * \quad \begin{array}{c}\text { Lahontan clays } \\
\text { and silts }\end{array}$ & 10 & 70 & 350 \\
12 & $\begin{array}{c}\text { Lahontan clays } \\
\text { and silts }\end{array}$ & 5 & 11 & 55 \\
$13 \quad \begin{array}{c}\text { Lahontan clays } \\
\text { and silts }\end{array}$ & 10 & 0.7 & 7 \\
15 & $\begin{array}{c}\text { Lahontan clays } \\
\text { and silts }\end{array}$ & 5 & 0.8 & 4 \\
16 & $\begin{array}{c}\text { Lahontan clays } \\
\text { and silts }\end{array}$ & 10 & 0.3 & 3 \\
\hline
\end{tabular}

${ }^{*}$ Estimated hydraulic conductivity is uncertain.

\section{Transmissivity of the Coarser Alluvium Evaluated from a Slug Test}

The hydraulic conductivity of alluvial sediments was estimated from injection slug testing of an unused 6-inch diameter water-supply well in Lovelock Valley, Nevada, HA073 (fig. 13). The testing was conducted on August 10, 2017.

\section{Field Procedures}

Well 14 was selected to estimate transmissivity of the younger alluvium coarser sediments in the southern region of Lovelock Valley (fig. 13). The well is $178 \mathrm{ft}$ deep and is screened in younger alluvium sand from 158 to $178 \mathrm{ft}$ with factory-cut slot perforations (table 2). The well is constructed of 6-5/8-inch diameter casing set in a 10-5/8-inch hole.

A total of 4.4 gallons ( 0.59 cubic feet $\left.\left[\mathrm{ft}^{3}\right]\right)$ of water was rapidly poured three consecutive times into the well. The well was instrumented with a pressure transducer. Depth to water was measured prior to the start of the test. Repeated waterlevel measurements were made to verify transducer-recorded water-level changes during each water-level recovery.

\section{Analysis}

The pre-test water level was $4.33 \mathrm{ft}$ below land surface datum (LSD). The well experienced 2.3 to $2.6 \mathrm{ft}$ of waterlevel rise each time the 4.4-gallon $\left(0.59 \mathrm{ft}^{3}\right)$ slug of water was poured into the well (fig. 14). The method of Bouwer and Rice (1976) was used with coded Excel spreadsheets (Halford and Kuniansky, 2002) to analyze the water-level recovery data and estimate a hydraulic conductivity of the nearby aquifer material of 20 feet per day (ft/day; fig. 14). The aquifer transmissivity, calculated as the product of the hydraulic conductivity and effective aquifer thickness (assumed to equal the well-screen length), is $400 \mathrm{ft}^{2} /$ day (table 4). Nearlyidentical water-level responses were observed in each of the three slug tests used in the analysis. 


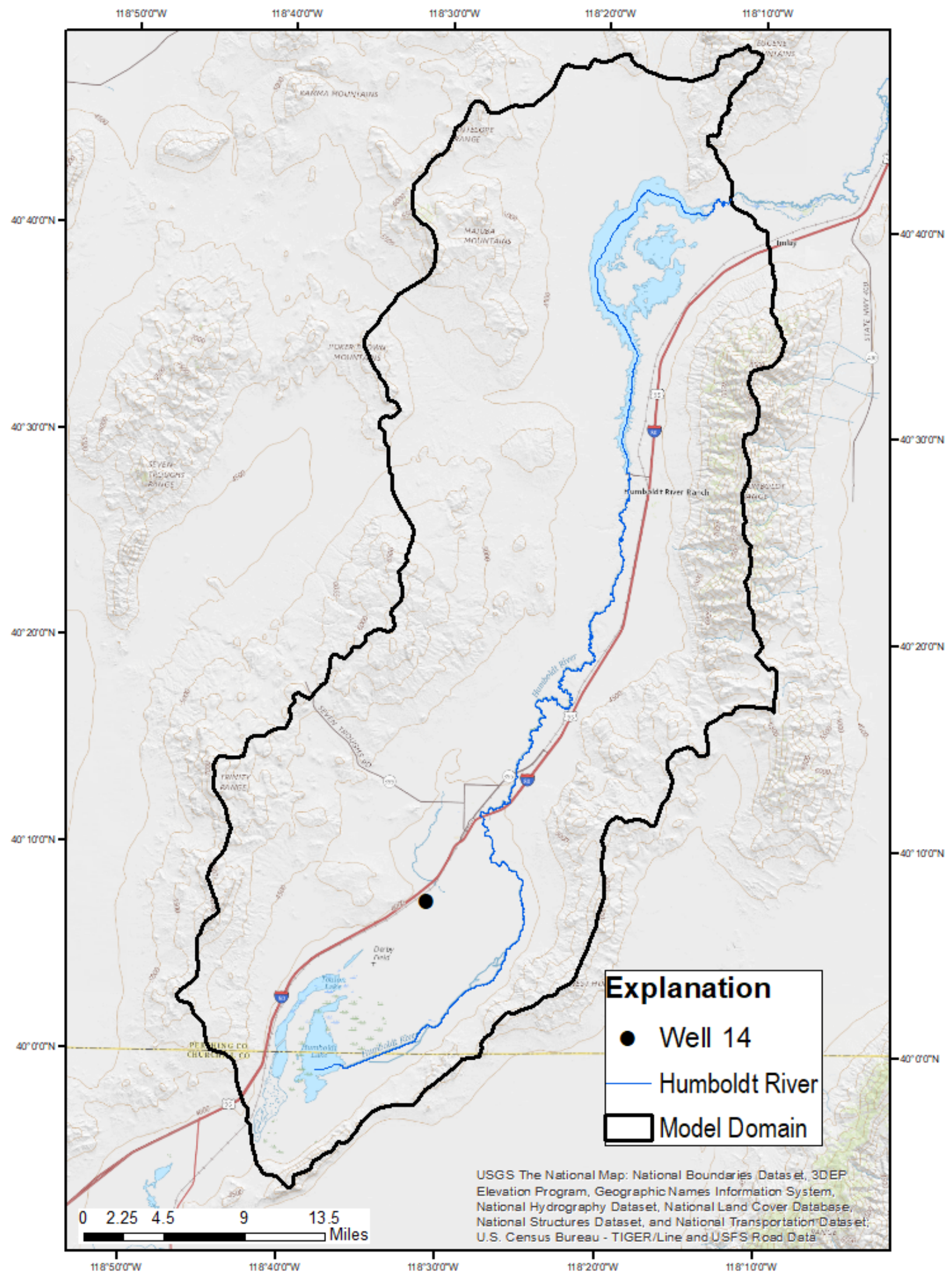

Figure 13. Location of Well 14 and the model domain for the lower Humboldt River Basin, Nevada, capture study. 


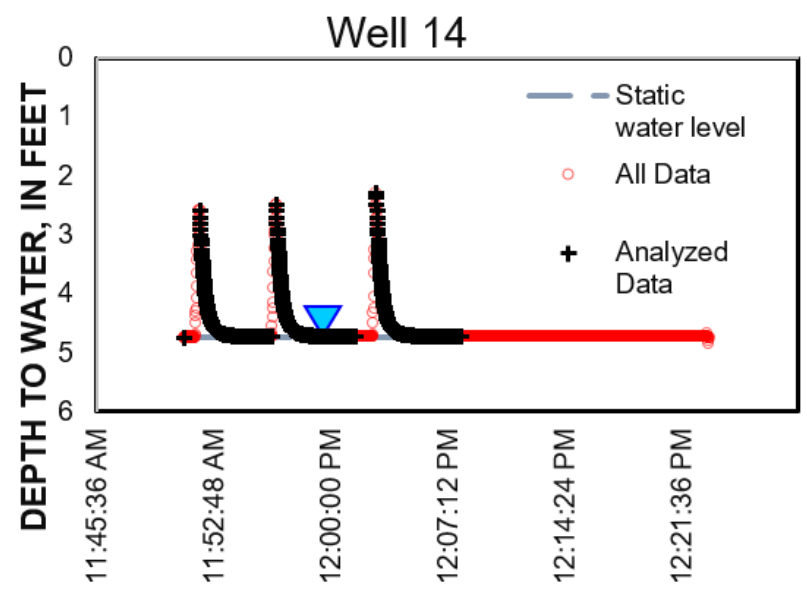

August 10, 2017

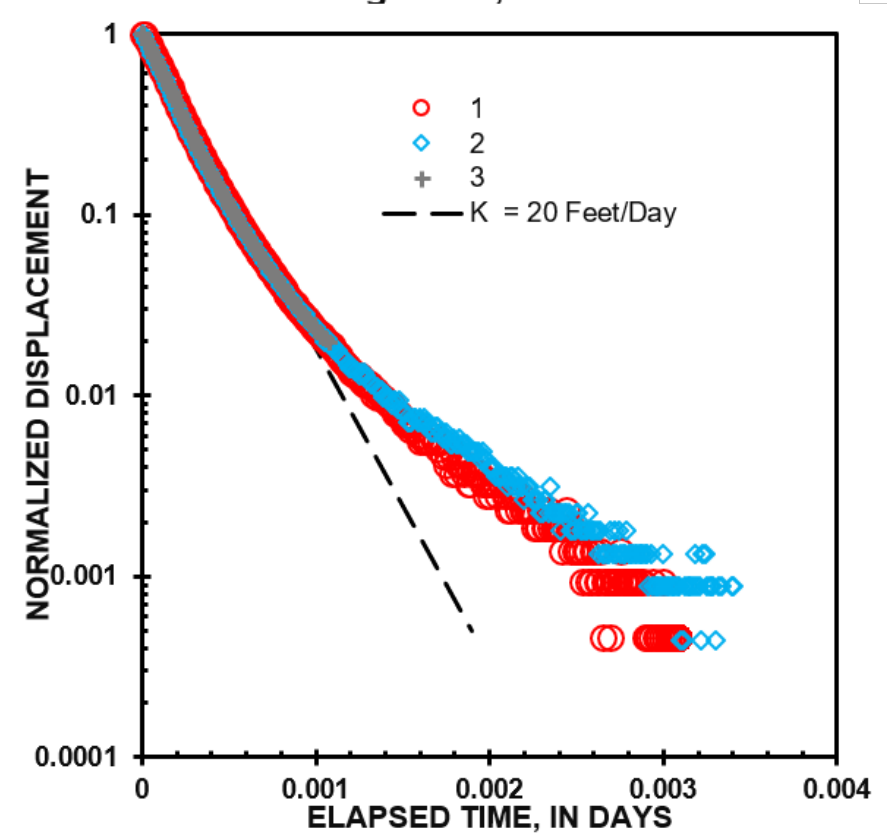

Figure 14. Water level response $(A)$ and analysis of hydraulic conductivity $(K)(B)$ of three injection slug tests (noted with red circles, blue diamonds, and green plus signs) conducted at Well 14 in Lovelock Valley, Nevada.
Table 4. Hydraulic conductivity and transmissivity estimates from the Bouwer and Rice (1976) analysis of slug-test data from Well 14 in Lovelock Valley, Nevada.

[ft, foot; ft/d, foot per day; $\mathrm{ft}^{2} / \mathrm{d}$, foot squared per day]

\begin{tabular}{lccc}
\hline Aquifer material & $\begin{array}{c}\text { Effective } \\
\text { thickness } \\
\text { (ft) }\end{array}$ & $\begin{array}{c}\text { Hydraulic } \\
\text { conductivity } \\
\text { (ft/d) }\end{array}$ & $\begin{array}{c}\text { Transmissivity } \\
\left.\text { (ft }{ }^{2} / \mathbf{d}\right)\end{array}$ \\
\hline Coarser alluvium & 20 & 20 & 400 \\
\hline
\end{tabular}

\section{Transmissivity of the Coarser Alluvium Evaluated from a Single-Well Pumping Test}

Transmissivity of alluvial sediments on the east side of the Humboldt River was estimated from a single-well pumping test conducted on a 12-inch diameter watersupply well in Lovelock Valley, Nevada, HA073 (fig. 15). The drawdown test was conducted on August 9, 2017, at 07:18 PDT (Pacific daylight time) and ended 8 hours and 18 minutes later at 15:36 PDT. Aquifer recovery was monitored for 21 hours and 21 minutes until August 10, 2017 , at 12:57 PDT. The test was conducted with a submersible pump which pumped at an average rate of 16.2 gallons per minute (gpm).

\section{Field Procedures}

Well 3 was selected to spatially extend estimates of transmissivity farther northeast than other tests in Lovelock Valley (fig. 15). The well is $190 \mathrm{ft}$ deep and is screened in the younger alluvium clays and gravels from 95 to $184 \mathrm{ft}$ with factory-cut slot perforations (table 2). The well is constructed of 12-inch diameter casing set in a 12-inch hole.

The well was instrumented with a pressure transducer to record water-level fluctuations during pumping and recovery. The pressure transducer was programmed to record water levels at 1-minute intervals. Depth to water was measured prior to the start of the test and repeated during the test to ensure accuracy of transducer-recorded water-level changes. 


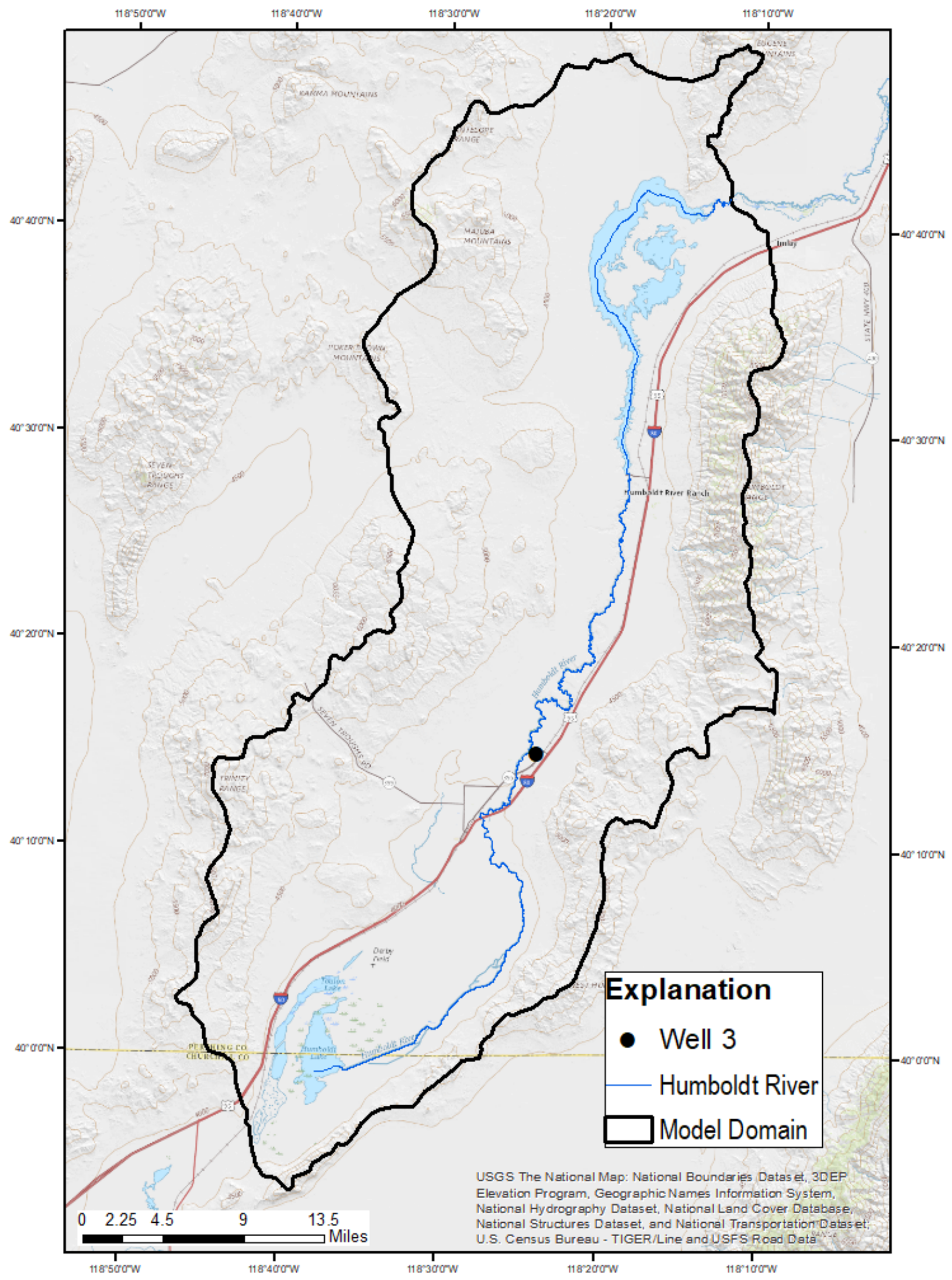

Figure 15. Location of Well 3 and the model domain for the lower Humboldt River Basin, Nevada, capture study. 
A submersible pump was placed approximately $65 \mathrm{ft}$ below the top of the well casing in the well and pumped at a near constant rate of 16.2 gpm for 8 hours and 18 minutes. Discharge rate from the pump was measured periodically using a calibrated bucket and stopwatch. Recovery was monitored for 21 hours and 21 minutes. Nearby pumping is believed to have caused an additional $0.5 \mathrm{ft}$ of drawdown about 5 hours into the test, which recovered in less than an hour. This additional drawdown is ignored in the analysis.

\section{Analysis}

The pre-pumping water level was $27.5 \mathrm{ft}$ below measuring point (MP). The pumped well experienced $13.6 \mathrm{ft}$ of drawdown during the pump test (fig. 16). The method of Cooper and Jacob (1946) was used to analyze the water-level drawdown data and estimate a transmissivity of the nearby aquifer material of $130 \mathrm{ft}^{2} /$ day (fig. 16).

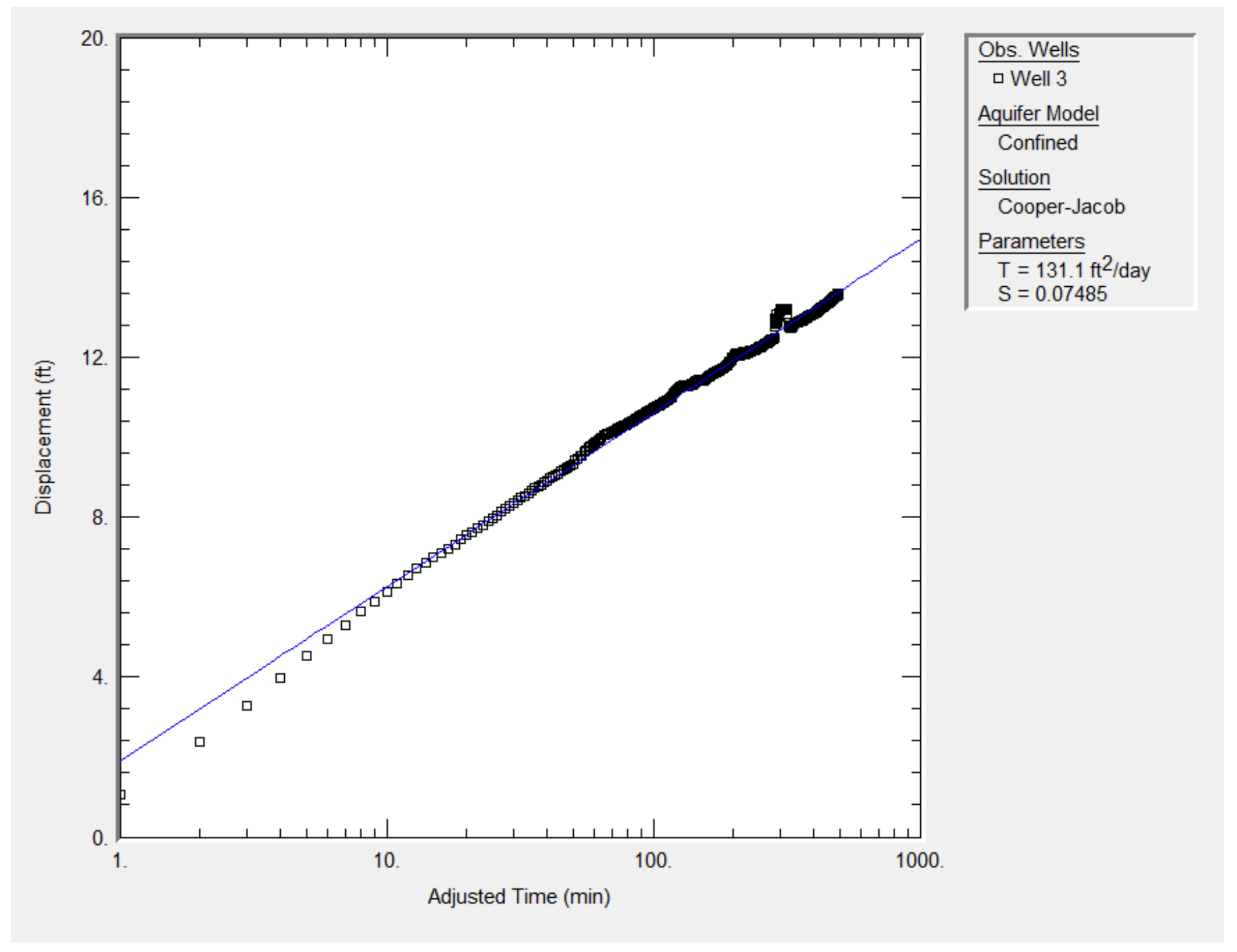

Figure 16. Cooper-Jacob analysis of drawdown data (displacement of water) for Well 3 in Lovelock Valley, Nevada. 


\section{Transmissivity of the Lahontan Clays and Silts, Fluvial Deposits, and Coarser Alluvium Determined from two Multi- Well Pumping Tests}

Two multi-well pumping tests were conducted to estimate aquifer properties over a much larger area than could be provided by the single well tests discussed in previous sections. The first test was conducted in March of 2017 and consisted of pumping Well 4 and concurrently monitoring seven observation wells. The second test was conducted in November and December of 2017 and consisted of pumping Well 10 and concurrently monitoring 15 observation wells. Observation and pumping wells were instrumented with pressure transducers to record water-level fluctuations before, during, and after each pumping test. Drawdowns from each test were estimated using water-level models to remove the influence of naturally occurring (environmental) waterlevel fluctuations from the data collected by the pressure transducers. A groundwater flow model was created for each pumping test to simulate surface water fluctuations that occurred during the first pumping test and asymmetric drawdown patterns that were observed during each pumping test. The groundwater-flow models were calibrated together to determine aquifer properties for Lovelock Valley that account for observations during each of the two pumping tests.

\section{Lithologic Descriptions of Wells}

Seventeen wells were used in the two multi-well pumping tests (table 2). Well logs were available for 14 of the wells (Wells 1-4, 6-9, 11-16), and an electric water-level tape was used to sound the bottom of the wells without logs (Wells 5, 9 , and 17). The pumping well for multi-well pumping test \#1 (MWP1), Well 4, is $530 \mathrm{ft}$ deep and is screened in the coarser alluvium sands and clays from 160 to $320 \mathrm{ft}, 360$ to $400 \mathrm{ft}$, and 400 to $520 \mathrm{ft}$ with mill slot perforations. The pumping well for multi-well pumping test \#2 (MWP2), Well 10, is $351 \mathrm{ft}$ deep and is screened in the coarser alluvium clays, sands, and gravels from 100 to $351 \mathrm{ft}$ with factory cut perforations. Wells 1 and 2 were drilled in sand of the coarser alluvium. Well 3 was drilled in clay and gravel of the coarser alluvium. Well 4 was drilled in clay and sand of the coarser alluvium. Well 5 does not have an associated well log; however, it is assumed to be completed in shallow Lahontan clays and silts. Wells 6 and 7 were drilled in clay and silt of Lahontan clays and silts. Well 8 was drilled in fine sand and silt of the Lahontan clays and silts. A drillers report was not available for Well 9, so screened interval and completion lithologies for the well were not known; however, it assumed the well is drilled in shallow sands, silts, or clays of the coarser alluvium. Well 10 is drilled in clays, silts, sands, and gravels of the coarser alluvium. Well 11 was drilled in gravel and sand of the coarser alluvium. Well 12 was drilled in clays and sands of the Lahontan clays and silts. Well 13 was drilled in clays, sands, and silts of the Lahontan clays and silts. Well 14 was drilled in sand of the coarser alluvium. Wells 15 and 16 were drilled in sands, silts, and clays of the Lahontan clays and silts. Well 17 does not have an associated well log; however, it is assumed to be completed in shallow Lahontan clays and silts (table 2).

\section{Field Procedures}

\section{Multi-Well Pumping Test \#1}

A multiple-well aquifer test was conducted to determine aquifer properties of the coarser alluvium and is hereto referred as multi-well pumping test \#1 (MWP1). The aquifer drawdown test began on March 8, 2017, at 13:40 Pacific standard time (PST) and ended on March 12, 2017, at 13:00 PST, for a duration of 96 hours and 40 minutes. Aquifer recovery was monitored for 24 days until April 5, 2017. The test consisted of a well pumping at a rate of $4,400 \mathrm{gpm}$ and monitoring water levels in seven observation wells located between 0.3 and 16.4 miles away from the pumping well. The pumping well is approximately 0.3 miles west of the Humboldt River (fig. 17).

The seven observation wells were instrumented with pressure transducers $1-5$ weeks prior to the test to record water-level fluctuations before, during, and after the test. Well 17 was used to observe background water levels and was not expected to be affected by the pumping well. An e-tape was used to measure depth to water at each well prior to the start of the test. Each pressure transducer recorded water levels at 15-minute intervals. Water-level measurements were made to verify the accuracy of transducer-recorded water levels throughout the data collection period.

A pressure transducer was installed in the pumping well prior to the test. A constriction between the pump column and the well casing limited the depth to which the transducer and e-tape could reach (about $20 \mathrm{ft}$ below land surface). Therefore, only a steel tape could be used for manual water-level measurements. Significant oil coated the inside of the well casing and was floating on top of the water in the well. Thus, the steel tape quickly became coated in oil, resulting in water-level measurements with large error (repeat measurements varied by as much as $5 \mathrm{ft}$ ). The steel tape was used to measure depth to water prior to the start of the test and at irregular intervals throughout the test. Overall accuracy of water levels measured in the pumping well were considered poor but acceptable for documenting the scale of drawdown that did occur. 


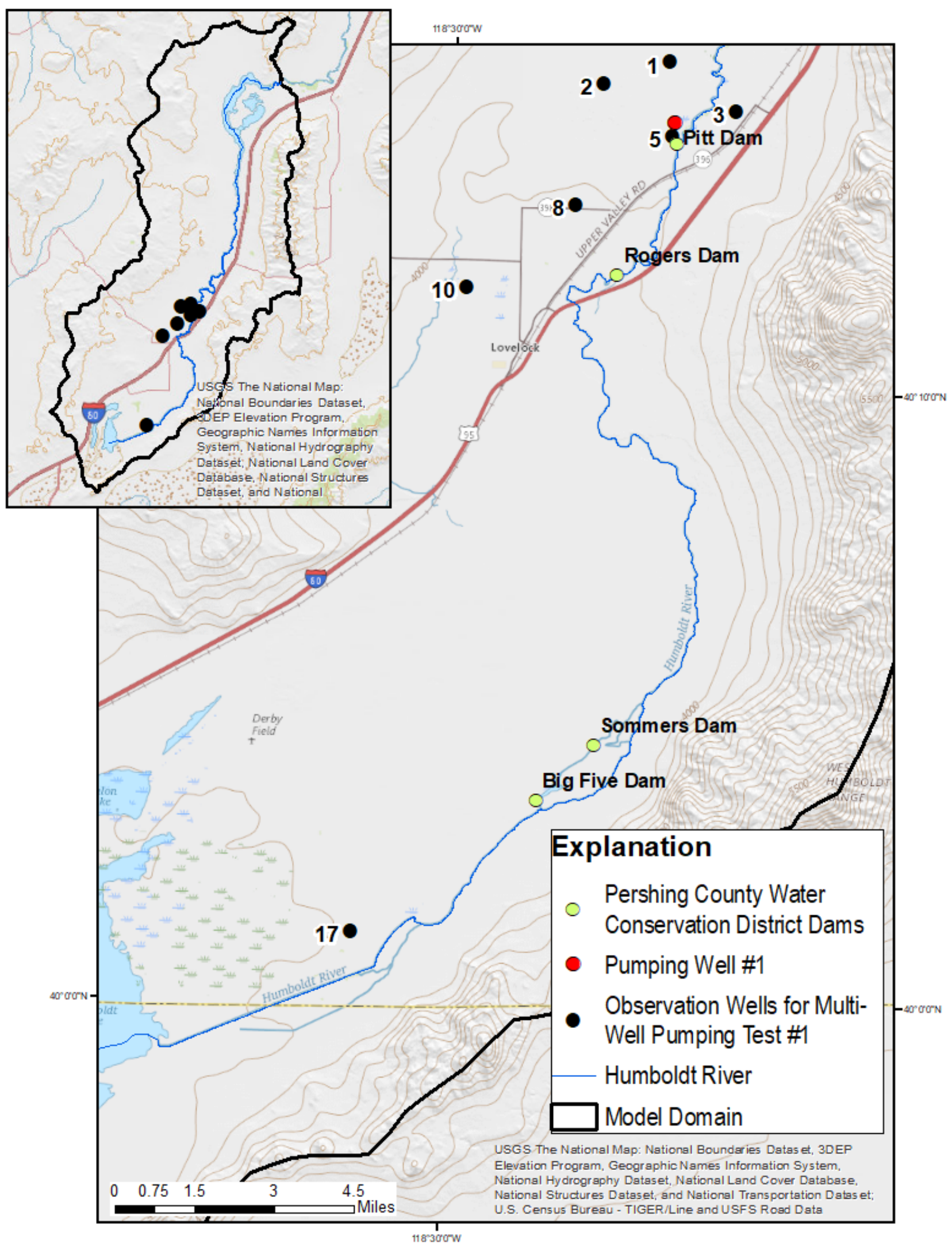

Figure 17. Location of Lovelock Valley, Nevada, multi-well pumping test \#1 showing the pumping well (red) and seven observation wells (black). 
Discharge rate from the pumping well was initially monitored using the well owner's permanent flowmeter installation and simultaneously recorded using an ultrasonic flowmeter (fig. 18). Both meters failed after the first day of pumping. Subsequently, pumping discharge was measured as open channel flow in the canal used to carry the pumped water away from the immediate test site. Measurements were made periodically throughout the duration of the test.

The nearby canal transported the discharged water to the main canal system and away from the pumping location (fig. 19). Well 5, a shallow (26.3 ft deep) stock well, located approximately 0.1 miles from the canal transporting discharged water, experienced a water-level rise of about $2 \mathrm{ft}$ during the test. This well is screened in the shallow, low-permeability Lahontan clays and silts, which probably prevent significant seepage to the deeper alluvial aquifer being pumped during the period of this test. Data for this well were not included in the analysis but may be used later for an accompanying single-well aquifer test.

The stage in the Humboldt River was approximately constant prior to the start of the pumping test. Water was released from Rye Patch Reservoir (a reservoir approximately 16.5 miles north of the test region) on the morning of March 13, 1 day after the pump was shut off. Water travels from Rye Patch Reservoir down the Humboldt River, passing the test region after about 18 hours (fig. 20). Stilling wells with pressure transducers were installed at the Pitt and Rogers Dams (points of diversion from the main channel of the Humboldt River; table 1) on March 10 and March 12, respectively, to monitor river stage changes resulting from the release. Stage was recorded at 30-minute and 1-hour intervals for the Pitt and Rogers Dams (fig. 17), respectively, to monitor changes in Humboldt River stage. Repeated measurements of depth to water in stilling wells were used to verify transducer performance throughout the data collection period. Depth to water in stilling wells at two downstream dams, Somers and Big Five Dams, were only intermittently measured with an electric water-level tape. The stage of the Humboldt River rose an approximate $5 \mathrm{ft}$ after water was released from Rye Patch Reservoir.

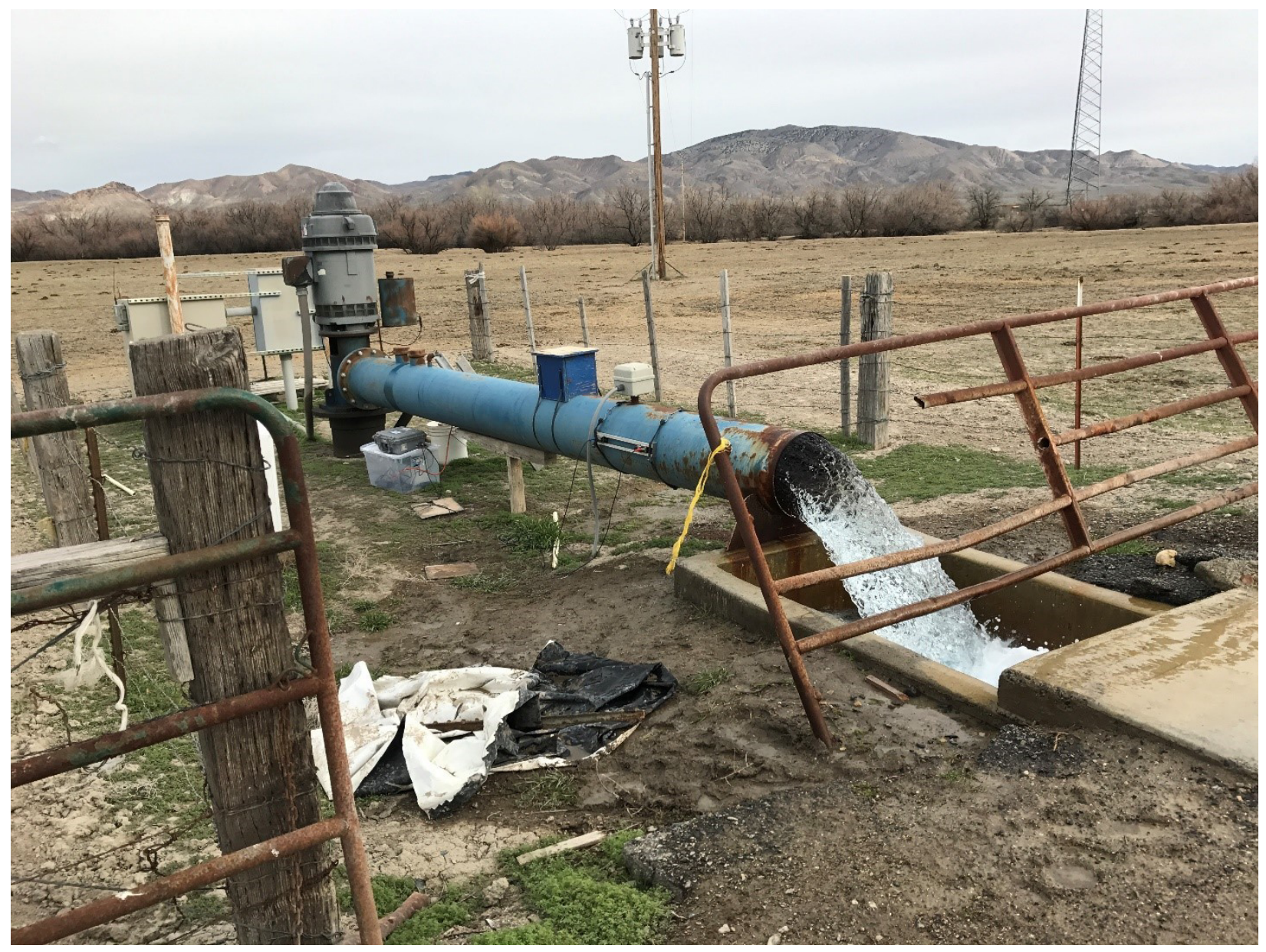

Figure 18. Pumping well of Lovelock, Nevada, discharging water at a rate of 4,400 gallons per minute into a nearby canal in Lovelock Valley, Nevada. The discharge pipe has a diameter of 16 inches. The permanently fixed flowmeter is in the blue box on top of the discharge pipe, and the portable ultrasonic flowmeter is affixed to the pipe below the beige box. Photo taken by Cara Nadler of the U.S. Geological Survey. 


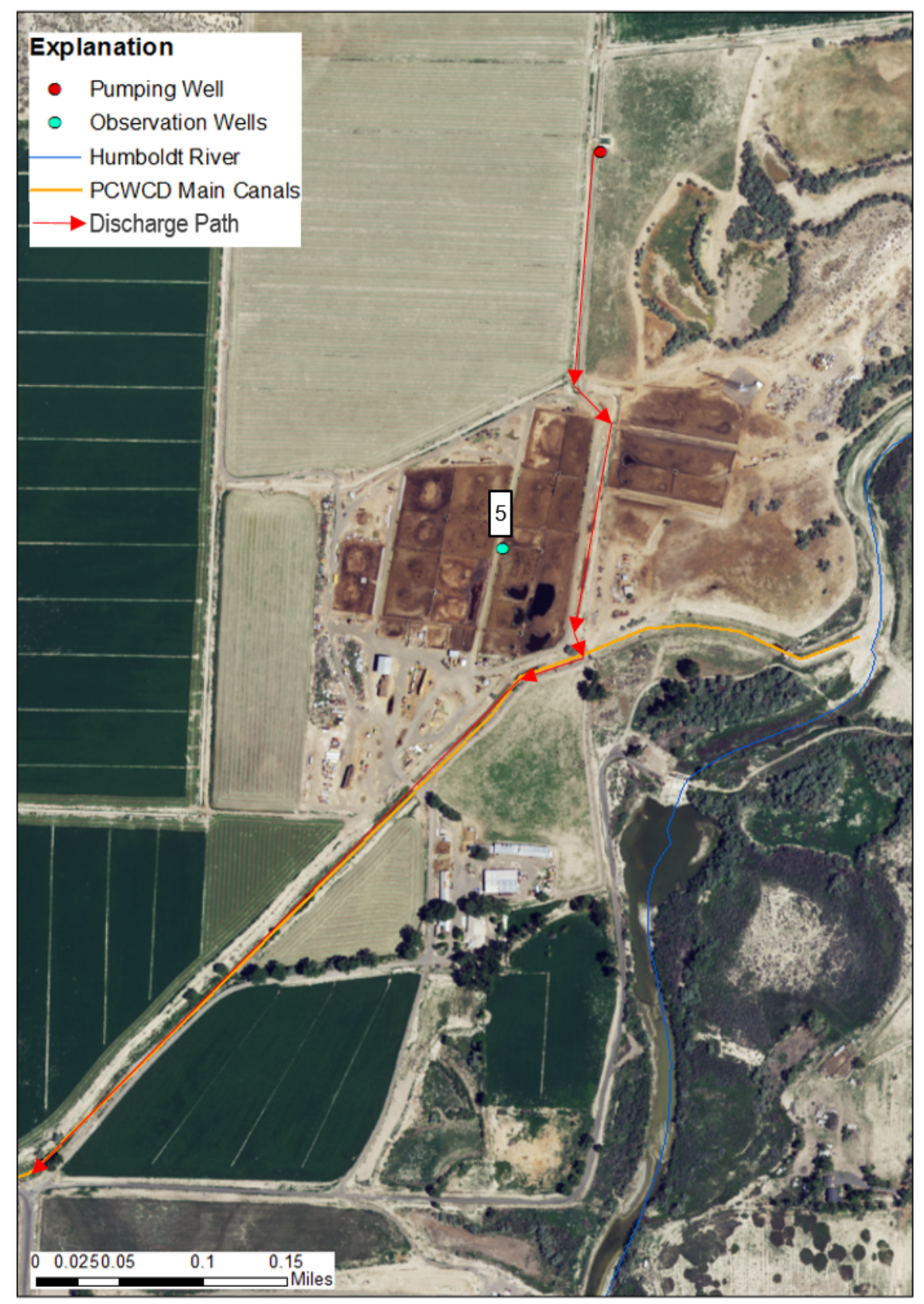

Figure 19. Water discharge path from the pumping well to canals in Lovelock, Nevada. PCWCD is the Pershing County Water Conservation District.

Pre-pumping water levels ranged from 6.65 to $26.77 \mathrm{ft}$ below land surface in the pumping well and seven observation wells. Wells 1 and 2 are located on the same side of the river as the pumping well. Well 1 is 1.16 miles from the pumping well and showed the most drawdown measured during the aquifer test at $11.5 \mathrm{ft}$. Well 2 is 1.55 miles from the pumping well and showed the second most drawdown measured during the test at $8.1 \mathrm{ft}$ (fig. 21). Well 3 is located on the opposite side of the river, 1.15 miles from the pumping well, and showed $0.3 \mathrm{ft}$ of drawdown. Temporal offsets in drawdown are likely caused by variations in distance from the pumping well and aquifer heterogeneity. Drawdown data for the remaining wells were all less than $0.3 \mathrm{ft}$ (Nadler, 2019). 


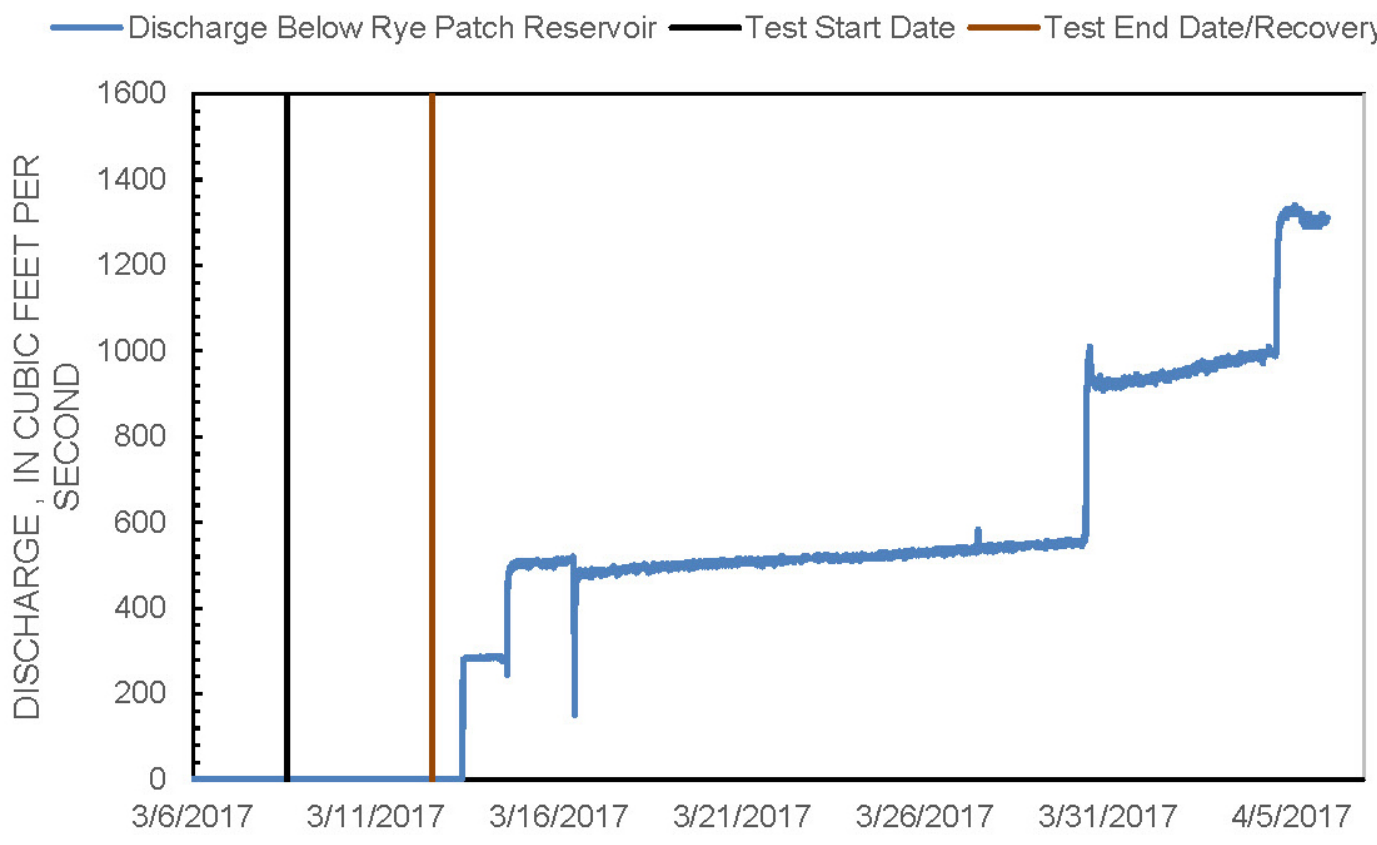

Figure 20. Discharge from USGS 10335000 HUMBOLDT RV NR RYE PATCH, NV.

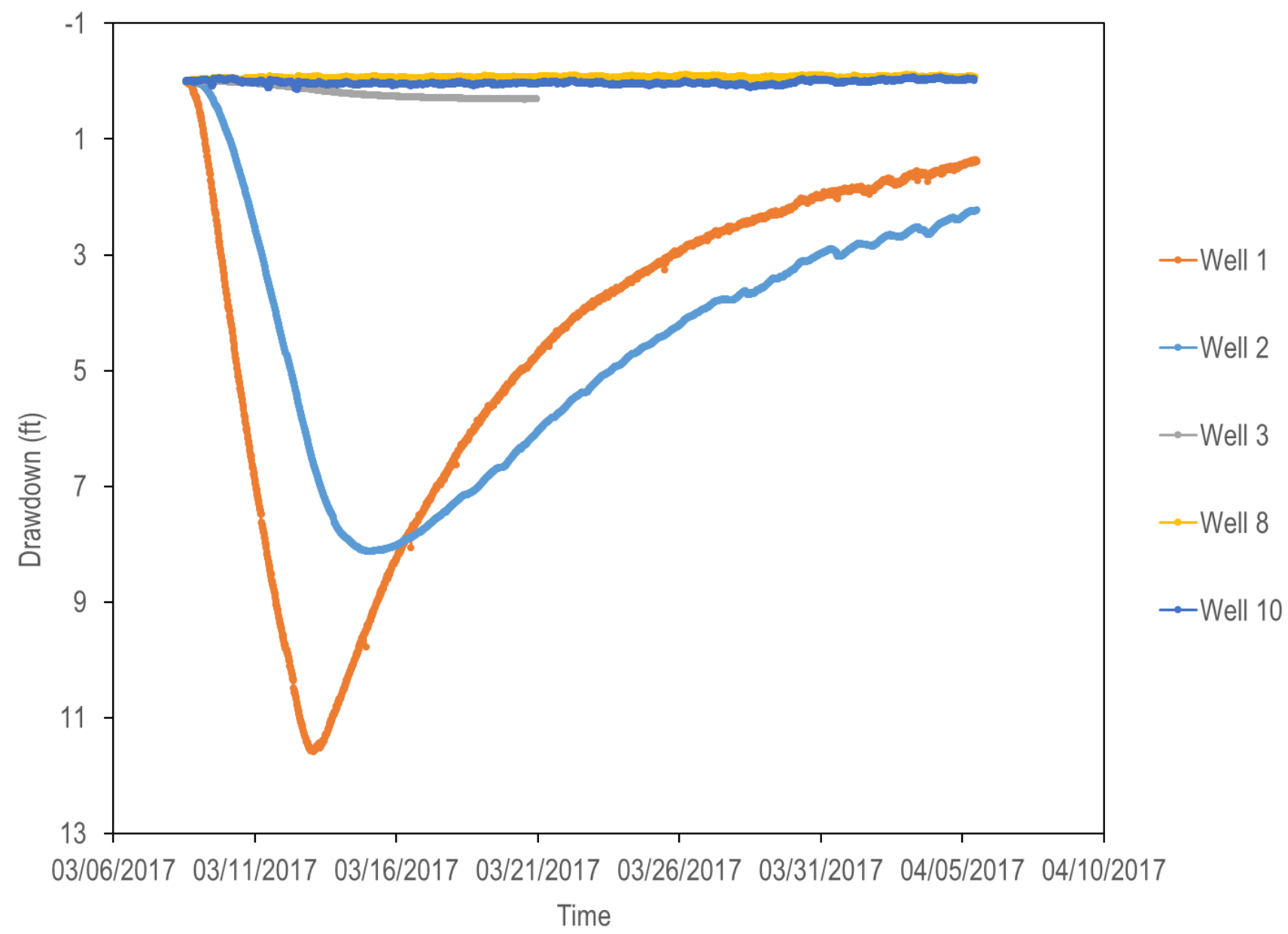

Figure 21. Drawdown of Wells 1, 2, 3, 8 and 10 in Lovelock Valley, Nevada, through time. 


\section{Multi-Well Pumping Test \#2}

A second multiple-well aquifer test, multi-well pumping test \#2 (MWP2), was conducted in Lovelock, Nevada, to estimate aquifer properties of the coarser sediments of the younger alluvium in areas beyond the reach of MWP1 and to further constrain estimates for overlapping areas investigated with MWP1. The aquifer drawdown test began on November 28, 2017, at 10:53 a.m. and ended on December 4, 2017, at 11:28 a.m., for a pumping duration of 144 hours and 35 minutes. Aquifer recovery was monitored for 31 days until January 4,2018 . The test consisted of a well pumping at a rate of $6,040 \mathrm{gpm}$ and concurrently monitoring 15 observation wells located up to 12.3 miles away from the pumping well. The pumping well is approximately 1.9 miles west of the Humboldt River (fig. 22).

The 15 observation wells and the pumping well were instrumented with pressure transducers 1-7 months prior to the test to record water-level fluctuations before, during, and after the test. Wells 15,16 , and 17 were used to observe background water levels and were not expected to be affected by the pumping well. Each pressure transducer was programmed to record water levels at 1-hour intervals until the week before the test. On November 20, 2017, transducers in the pumping well and Wells 8, 9, 11, 12, and 13 were reprogrammed to record water levels at 15-minute intervals. An e-tape was used to measure depth to water at each well, except Well 11, prior to the start of the test. A constriction in Well 11 between the pump column and the well casing limited the depth to which the transducer and e-tape could reach (about $7 \mathrm{ft}$ below land surface). Therefore, a steel tape was used to measure water levels. Repeated water-level measurements were made to verify transducer performance throughout the data collection period. Discharge rate from the pumping well was monitored using the well owner's permanently installed flowmeter (fig. 23). Measurements were recorded periodically throughout the duration of the test. A nearby canal transported the discharged water to a Pershing County Water Conservation District drain.

Pre-pumping water levels ranged from 3.33 to $26.04 \mathrm{ft}$ below land surface in the pumping well and 15 observation wells. Well 11 is 0.6 miles from the pumping well and showed the most drawdown measured during the aquifer test at $9.0 \mathrm{ft}$. Well 9 is 1.0 miles from the pumping well and showed the second most drawdown measured during the test at $2.6 \mathrm{ft}$ (fig. 24). Recovery data for wells 9 and 11 could be muted by lingering effects of streamflow capture and/or well proximity to a no-flow boundary. Drawdown data for the remaining wells were all less than $0.2 \mathrm{ft}$ (Nadler, 2019).

\section{Analyses of Aquifer Properties Using Numerical Methods}

Drawdowns from each multi-well pumping test were estimated using water-level modeling to remove environmental fluctuations from the transducer data. The sum of the Theis transform model and the residuals that resulted from the fitting process was used to estimate the magnitude of the drawdown in each well. The data were then used in two groundwater flow models to estimate aquifer properties. Analytical methods for the two multiwell pumping tests would be limited because such methods could not incorporate (1) the effect of the rising river stage during the recovery of multi-well pumping test \#1 or (2) the apparent aquifer heterogeneity suggested by observed spatially asymmetric drawdowns. Analytical solutions would also not solve for a common set of properties for the overlapping regions of the aquifer volume tested. For these reasons, a numerical groundwater flow model was developed for each pumping test: the MWP1 model and the MWP2 model. The groundwater flow models were calibrated with ModelIndependent Parameter Estimation and Uncertainty Analysis (PEST; Doherty, 2008; Doherty and Hunt, 2010). The two models (MWP1 and MWP2) run in sequence with PEST to solve for the same aquifer properties. Hydraulic-conductivity distribution was estimated by minimizing the difference between measured and simulated water levels in both aquifer tests.

\section{Estimated Drawdowns Using Water-Level Modeling}

Drawdowns from pumping of Wells 4 and 10 were estimated by modeling water levels in the pumping and observation wells. Water-level modeling was necessary because environmental (naturally occurring) water-level fluctuations of more than $0.2 \mathrm{ft}$ exceeded maximum drawdowns from pumping in many observation wells. Drawdowns were differentiated from environmental fluctuations by modeling synthetic water levels that simulated environmental water-level fluctuations and pumping effects. Environmental water-level fluctuations were simulated by summing individual time-series of barometric pressure and distant background water-level fluctuations (Halford, 2006). Pumping responses were simulated by superposition of multiple Theis solutions. 


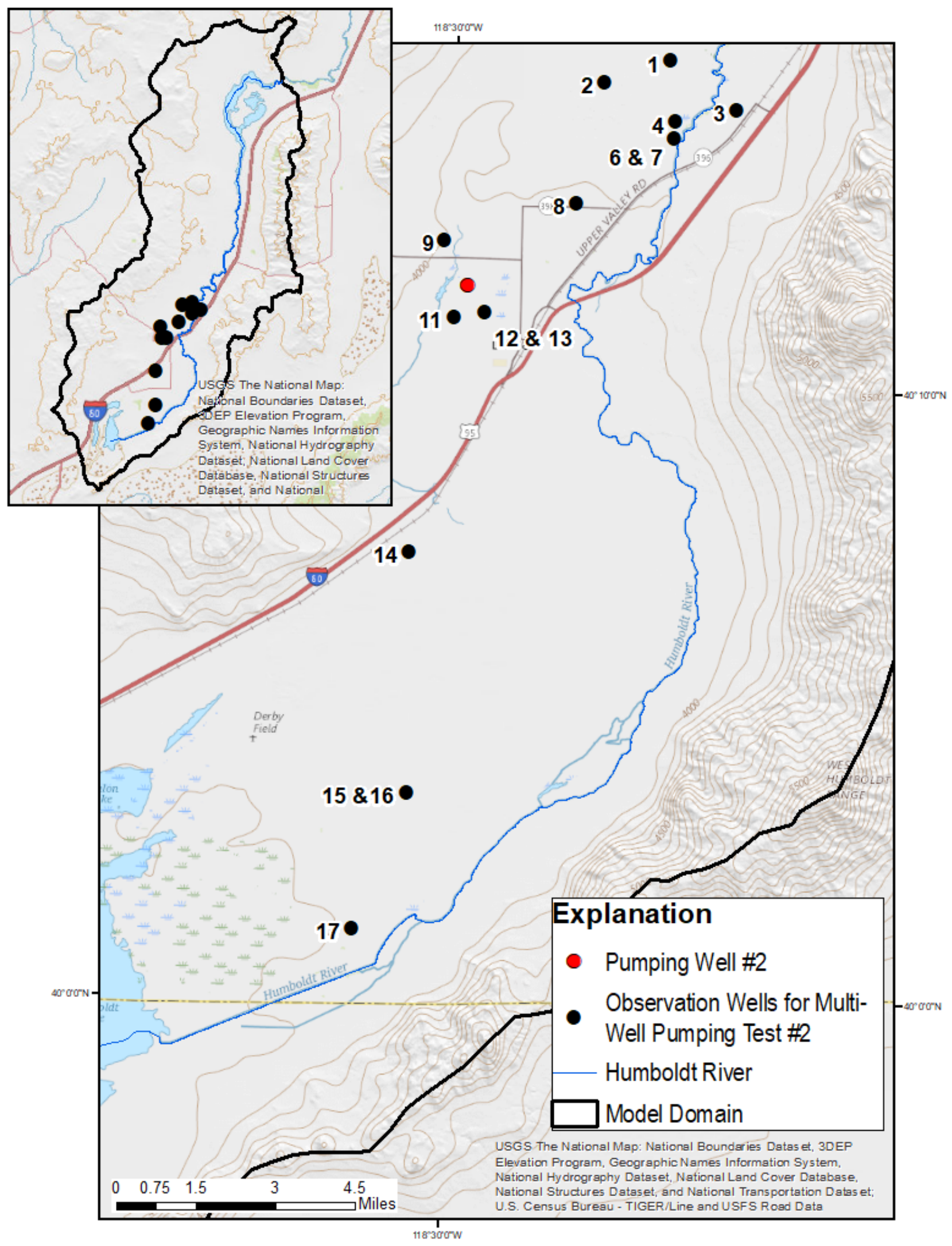

Figure 22. Location of Lovelock Valley, Nevada, multi-well pumping test \#2 showing the pumping well (red) and fifteen observation wells (black). 


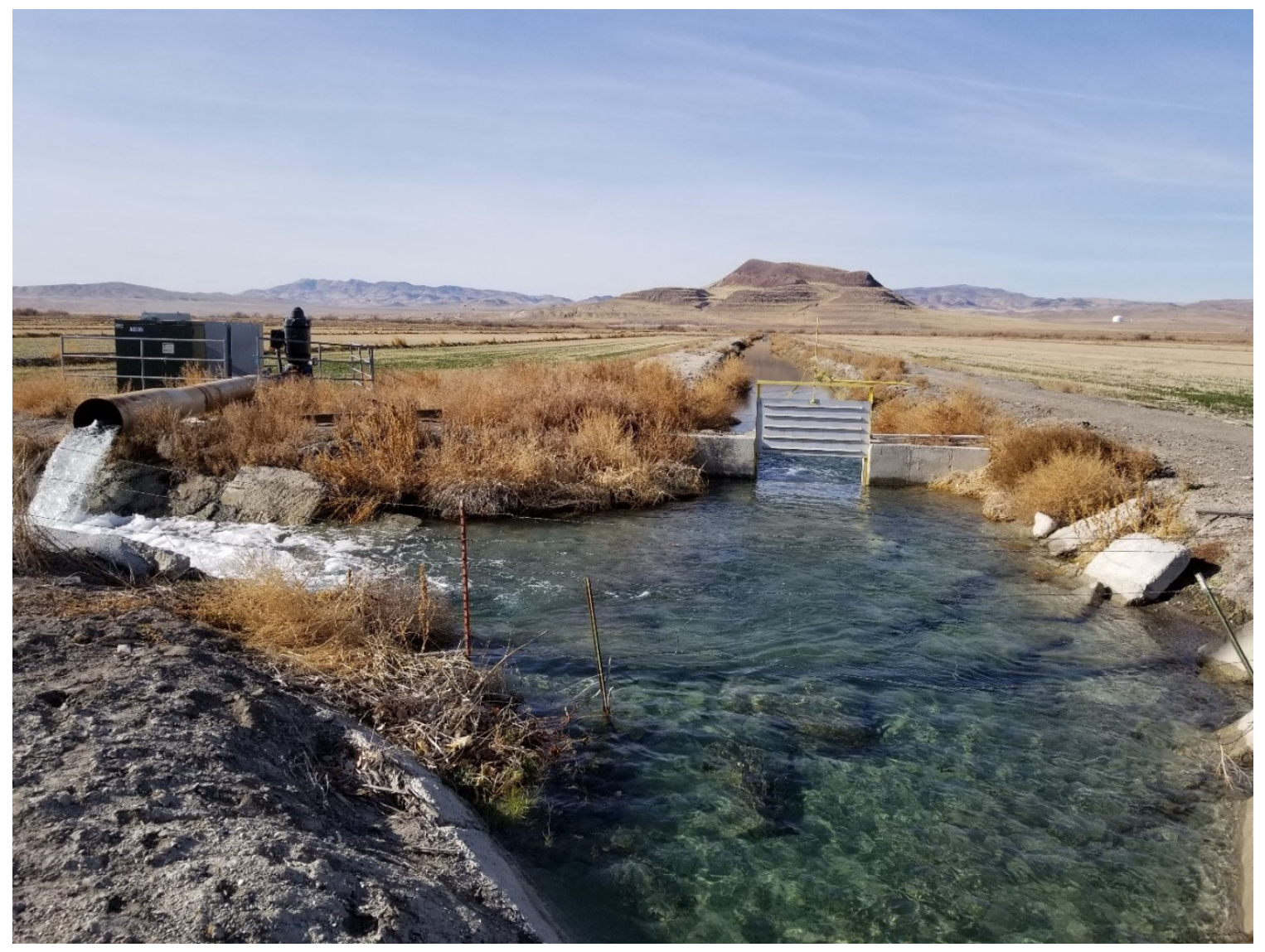

Figure 23. Pumping well discharging water at a rate of 6,038 gallons per minute into a nearby canal in Lovelock Valley, Nevada. Photo taken by Kyle O'Connor of the U.S. Geological Survey.

Environmental water-level fluctuations were simulated with time series of barometric pressures and water levels from background Well 17 (fig. 17). This background well is assumed close enough to the observations wells to be affected by similar natural environmental fluctuations, yet distant enough to be unaffected by pumping from Wells 4 and 10 . Water levels from the background well were critical because they were affected by seasonal climatic trends and imperfect coupling of barometric and water-level trends. These effects also are assumed to be present to some degree in the observation wells.

Pumping responses from Wells 4 and 10 were modeled with a superposition Theis model. Superposition Theis models served as simple transform functions, where step-wise pumping records were translated into approximate drawdown responses. Numerical experiments have confirmed that superposition Theis models closely approximate water-level responses through hydrogeologically complex aquifers (Harp and Vesselinov, 2011). This approach will herein be referred to as the Theis transform model.
Synthetic water levels were fit to measured water levels by minimizing a sum-of-squares objective function (Halford, 2006). Amplitude and phase were adjusted in each time series that simulated environmental water-level fluctuations. Theis transform model parameters (transmissivity and storage coefficient) were adjusted in the fitting process. Estimated values of transmissivity and storage coefficient from the Theis transform model generally are not representative estimates of aquifer properties because the underlying assumptions of the Theis solution are generally grossly violated.

Extraneous time series, time series that do not correlate with fluctuations in the observation well, are functionally eliminated because estimates of amplitude will approach zero if the simulated time series does not improve fitting of the observed time series. For example, environmental fluctuations occurring in a background well but not in the observation well are ignored during the fitting process. Simulated pumping responses also can be eliminated functionally by Theis parameters becoming very large and being assigned a negligible amplitude. 


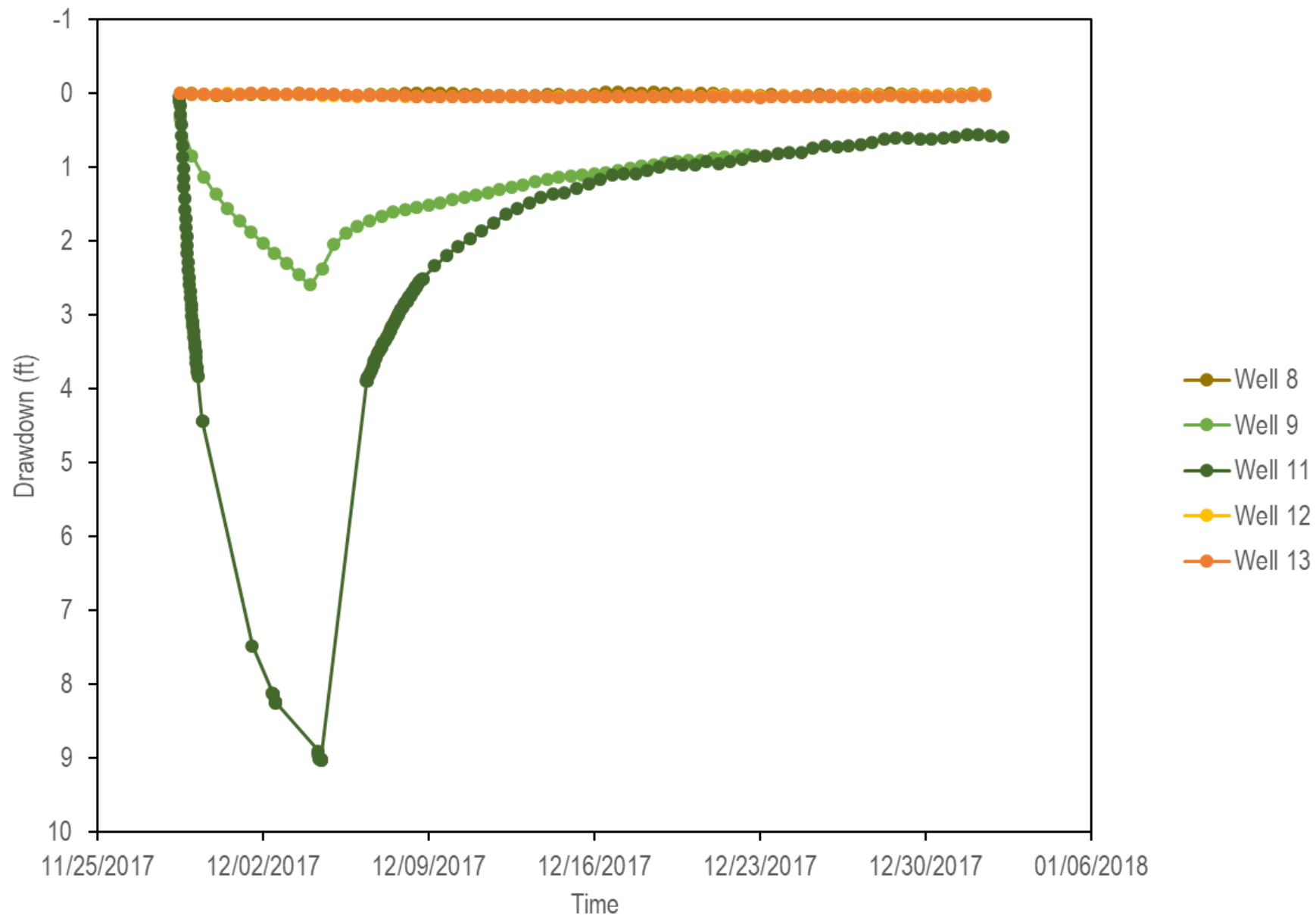

Figure 24. Twelve-hour averaged drawdowns of Wells 8, 9, 11, 12, and 13 in Lovelock Valley, Nevada through time.

Drawdown estimates were determined by summing the Theis transform models with the differences (residuals) between synthetic and measured water levels. Synthetic water levels matched measured water levels with root-mean-square (RMS) fitting errors between 0.0037 and $0.2567 \mathrm{ft}$ in all wells, except for water levels in background Well 17 during multi-well pumping test $\# 1$, when a water-level rise caused by the start of irrigation season was not being synthesized or matched. Pumping effects were considered definitive where the maximum synthetic drawdown estimate in a well exceeded $0.05 \mathrm{ft}$. This drawdown threshold was considered acceptable because it is large relative to the RMS fitting errors between synthetic and measured water levels. That is, greater drawdown estimates were associated with greater RMS errors, and lesser drawdown estimates were associated with lesser RMS errors. The drawdown threshold was found to be accepted based on the drawdown estimate to RMS error ratio resulting in the analyses.
Multi-Well Pumping Test \#1 (MWP1) Water-Level Models

Drawdowns resulting from the pumping of Well 4 were approximated for six observation wells (table 5). Drawdowns in the pumping well and observation Well 5 were not evaluated owing to poor data quality and complications caused by water release to a nearby canal and recharge in the shallow aquifer. Estimated drawdowns were relatively large in three wells $(0.25 \mathrm{ft}$ or greater), small in two wells $(0.08-0.12 \mathrm{ft})$, and less than the drawdown-detection threshold $(0.05 \mathrm{ft})$ in one well (table 5). The relative degree of certainty that the estimated drawdown is large enough to be distinguished from background noise in the data is provided in table 5. A well with a low relative certainty indicates that drawdown is highly uncertain or was not detected in the well. If drawdown was detected, it is poorly constrained and probably has a magnitude that is equal to or less than the estimated drawdown. High relative certainty indicates high probability that drawdown was detected in the well. 
Table 5. Drawdowns estimated with water-level models for observation wells in Lovelock Valley, Nevada, during multi-well pumping test \#1 (MWP1).

[Relative certainty that drawdown detected is a relative scale indicating the likelihood that estimated drawdown is large enough to be observed above background noise in data in which high is very likely, moderate is more probable than not, and low means drawdown could be or is negligible. Abbreviations: ft, foot; RMS, root-mean-square]

\begin{tabular}{rccc}
\hline Well & $\begin{array}{c}\text { Estimated } \\
\text { drawdown } \\
\text { (ft) }\end{array}$ & $\begin{array}{c}\text { Relative certainty } \\
\text { of drawdown } \\
\text { detection }\end{array}$ & $\begin{array}{c}\text { RMS error } \\
\text { (ft) }\end{array}$ \\
\hline 1 & 11.578 & High & 0.2297 \\
2 & 8.184 & High & 0.2567 \\
3 & 0.267 & High & 0.0312 \\
8 & 0.0838 & Low & 0.0118 \\
10 & 0.115 & Moderate & 0.0115 \\
17 & 0.0120 & Low & 5.8167 \\
\hline
\end{tabular}

\section{Multi-Well Pumping Test \#2 (MWP2) Water-Level Models}

Drawdowns resulting from the pumping of Well 10 were approximated for 14 observation wells (table 6). Drawdowns in the pumping well and observation Well 2 were not evaluated owing to poor data quality. Estimated drawdowns were relatively large $(0.1 \mathrm{ft}$ or greater $)$ in five wells, small $(0.05-0.1 \mathrm{ft})$ in five wells, and less than the drawdowndetection threshold $(0.05 \mathrm{ft})$ in four wells (table 6$)$. The relative degree of certainty that the estimated drawdown is large enough to be distinguished from background noise in the data is provided in table 6 .

\section{Groundwater Flow Models}

Two numerical groundwater flow models, developed with MODFLOW 2005 (Harbaugh, 2005), were used to analyze the aquifer tests to (1) represent the effect of rising river stage during the recovery of MWP1, (2) simulate the apparent aquifer heterogeneity suggested by observed asymmetric drawdown in MWP1, and (3) find a common set of properties that satisfy both large-scale pumping tests for overlapping regions of the aquifer volume tested. The MWP1 and MWP2 models are spatially discretized the same. The models both contain 117 columns and 157 rows. Model grid cells are $500 \mathrm{ft} \times 500 \mathrm{ft}$ in the region surrounding the pumping wells and nearby observation wells. Cell size increases with distance away from the pumping wells with a constant multiplier of 1.2 to a maximum size of $5,000 \mathrm{ft} \times 5,000 \mathrm{ft}$ (fig. 25). The models are vertically discretized in seven layers, representing three conceptual hydrogeologic units (fig. 26). The uppermost layer is $1 \mathrm{ft}$ thick and represents the water table. This layer is simulated as confined to aid in model run times during calibration; however, specific storage was assigned a value
Table 6. Drawdowns estimated with water-level models for observation wells in Lovelock Valley, Nevada, during multi-well pumping test \#2 (MWP2).

[Relative certainty that drawdown detected is a relative scale indicating the likelihood that estimated drawdown is large enough to be observed above background noise in data in which high is very likely, moderate is more probably than not, and low means drawdown could be or is zero. Abbreviations: ft, foot; RMS, root-mean-square]

\begin{tabular}{rccc}
\hline Well & $\begin{array}{c}\text { Estimated } \\
\text { drawdown } \\
\text { (ft) }\end{array}$ & $\begin{array}{c}\text { Relative certainty } \\
\text { that drawdown } \\
\text { detected }\end{array}$ & $\begin{array}{c}\text { RMS error } \\
\text { (ft) }\end{array}$ \\
\hline 1 & 0.126 & Moderate & 0.0113 \\
3 & 0.047 & Low & 0.0037 \\
4 & 0.105 & Moderate & 0.0106 \\
6 & 0.1217 & Low & 0.0480 \\
7 & 0.0968 & Low & 0.0396 \\
8 & 0.0428 & Low & 0.0136 \\
9 & 2.629 & High & 0.0148 \\
11 & 9.030 & High & 0.0336 \\
12 & 0.0604 & Moderate & 0.0068 \\
13 & 0.0615 & Moderate & 0.0063 \\
14 & 0.0386 & Low & 0.0041 \\
15 & 0.0629 & Low & 0.0147 \\
16 & 0.0840 & Low & 0.0176 \\
17 & 0.0462 & Low & 0.0152 \\
\hline
\end{tabular}

representative of specific yield (0.15) to allow this layer to behave as unconfined.

Accurate representation of transient leakage caused by groundwater storage changes in the Lahontan clays and silts is needed to adequately simulate drawdowns or lack thereof in the seven wells screened in the Lahontan clays and silts. The confining unit of the Lahontan clays and silts is discretized into five layers to improve model simulation of results in the confining unit (Leake and others, 1994; Leake and Prudic, 1988). These middle five layers that represent the Lahontan clays and silts and the fluvial deposits are each $10 \mathrm{ft}$ thick. The lowermost layer is $500 \mathrm{ft}$ thick and represents the coarser alluvium.

In the MWP1 model, three transient stress periods are used to represent a 4-day period of pumping, a 1.75-day period of recovery with no changes in Humboldt River stage, and approximately 34 days of recovery with a 5-ft water-level rise in the Humboldt River. In the MWP2 model, two transient stress periods are used to represent a 6-day period of pumping and approximately 31 days of recovery. In both models, the Humboldt River is simulated using the MODFLOW TimeVarying Specified-Head (CHD) Package (Harbaugh, 2005), and the pumping well is simulated with the MODFLOW Well (WEL) Package (Harbaugh and others, 2000). 


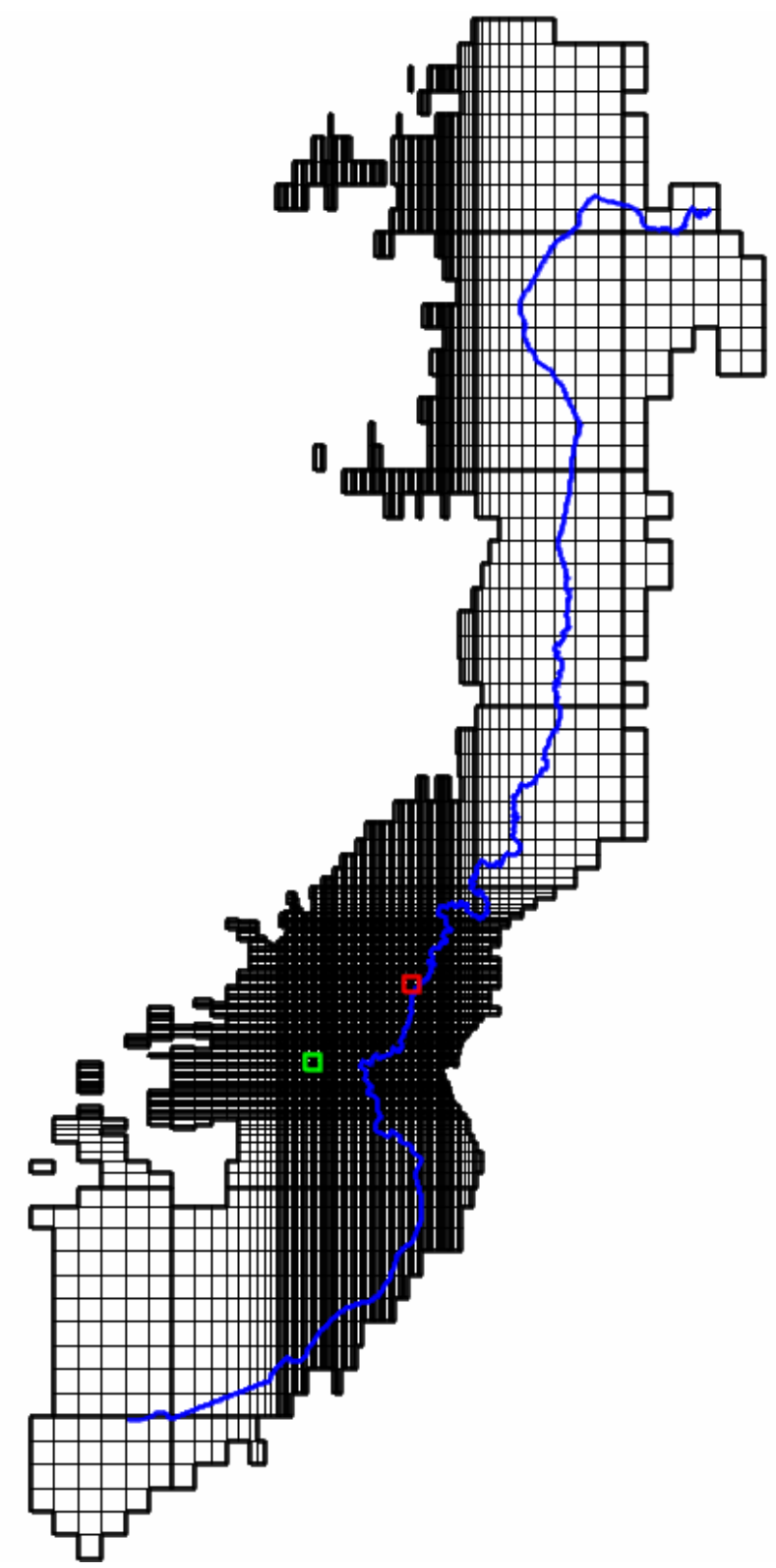

Figure 25. Grid discretization of the active model cells for both multi-well pumping test \#1 (MWP1) and multi-well pumping test \#2 (MWP2) models. The Humboldt River, Nevada, is shown in blue, MWP1 pumping Well 4 is shown in red, and MWP2 pumping Well 10 is shown in green.

A homogenous aquifer conceptualization was initially assumed to represent the aquifer property distribution but inadequately simulated the drawdown contrasts observed over short distances on opposite sides of the river during MWP1. Zones were used to introduce heterogeneity to both models and to improve simulation fits of the asymmetric drawdown pattern observed. A fluvial deposit zone, modified from Maurer and others (2004), is represented in conceptual model layers 1 and 2 to account for coarser fluvial sediments with higher transmissivities in the immediate vicinity of the Humboldt River channel (figs. 2, 27). Pilot points were used to allow for further heterogeneity in the layer 1-3 zones (figs. 27, 28). It is likely that the river is underlain by Lahontan clays and silts in some areas. While the simplified conceptualization of the fluvial deposits layering does not directly represent these deposits, the use of pilot points in the fluvial deposits zone allows hydraulic conductivity values to spatially vary and represent more and less confined underlying conditions.

After preliminary calibration tests, specific storage was found to be difficult to estimate in the presence of a leaky confined aquifer. Specific storage trended toward the lowest allowable values. The pumping wells were sourcing their water not only from storage of the coarser alluvium, but also from leakage through the overlying Lahontan clays and silts. With the presence of the Humboldt River, simulated as a constant head model boundary, abundant leakage reduced the amount of storage depletion required for each pumping well, lowering the estimated specific storage values required to calibrate the model. Thus, each of the five model layers representing the Lahontan clays and silts and the lowermost model layer representing the basin-fill aquifer are assigned a specific storage value of $4 \mathrm{E}-06$.

\section{Parameter Estimation and Goodness of Fit}

Hydraulic-conductivity distribution was estimated by minimizing a weighted composite, sum-of-squares objective function through the process of model calibration. This distribution was defined with 145 pilot points where 111 pilot points were adjusted with PEST (Doherty, 2008). Differences between measured and simulated observations defined the goodness-of-fit or improvement of calibration. These differences, or residuals, were weighted and summed in the objective function,

$$
\Phi(x)=\sum_{i=1}^{n o b s}\left[\left(\hat{o}_{i}-o_{i}\right) w_{i}\right]^{2}
$$

where

$$
\begin{gathered}
x \text { is the vector of parameters being estimated, } \\
\text { nobs the number of observations that are } \\
\text { compared, } \\
\left(\hat{o}_{i}\right) \text { is the } i^{\text {th }} \text { simulated observation, } \\
\left(o_{i}\right) \quad \text { is the } i^{\text {th }} \text { measurement or regularization } \\
\text { observation, and } \\
w_{i} \text { is the } i^{\text {th }} \text { weight. }
\end{gathered}
$$

Although the sum-of-squares error serves as the objective function, root-mean-square (RMS) error was reported because RMS error was compared easily to measurements. Root-meansquare error is

$$
R M S=\sqrt{\Phi / \sum_{i=1}^{n o b s}\left[w_{i}\right]^{2}}
$$




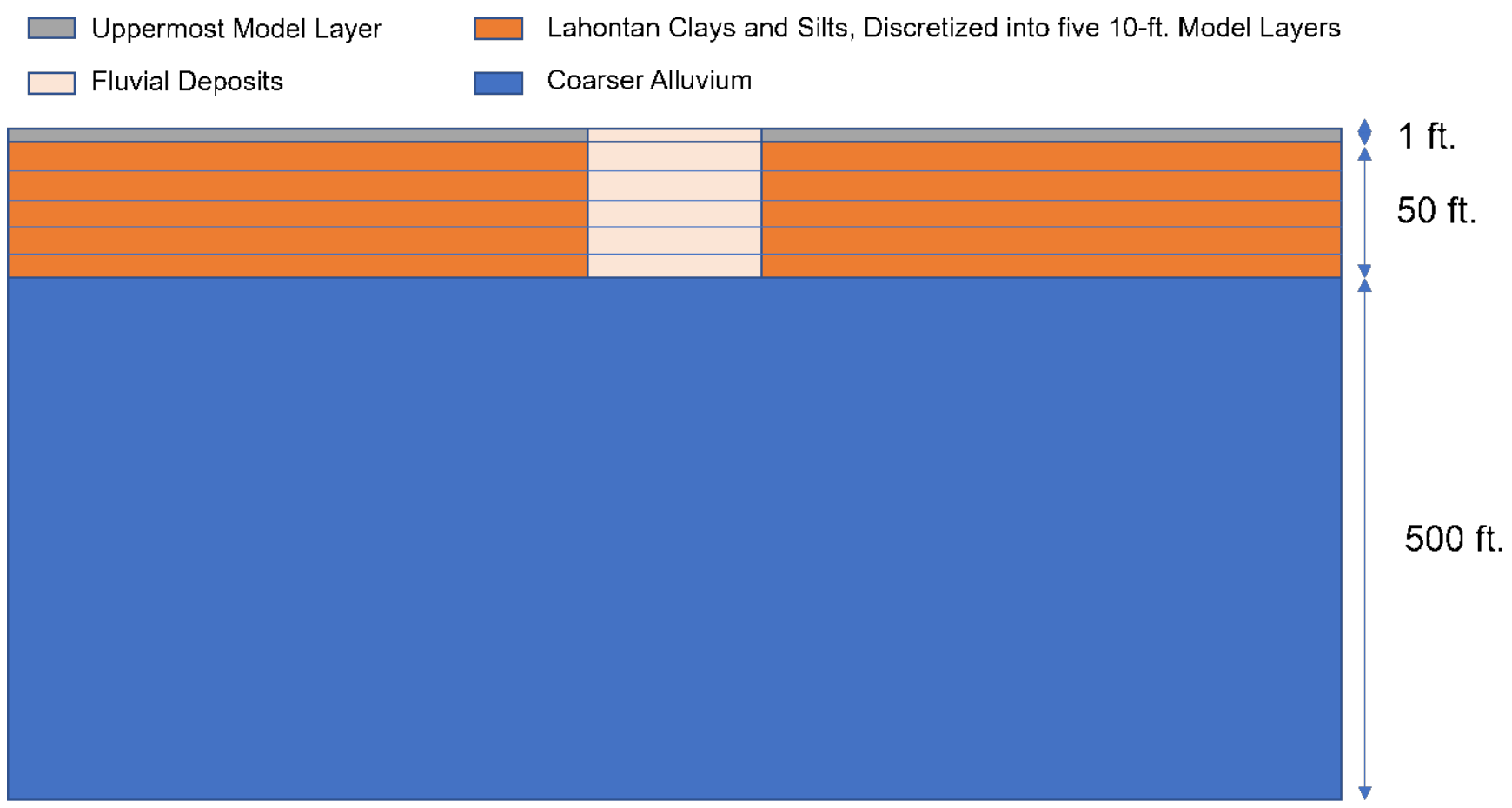

Figure 26. Simplified cross-section of hydrogeologic units used in the MODFLOW models, not drawn to scale.

Measurement and regularization observations controlled model calibration. The models used 1,173 drawdown estimates as measurement observations. Estimated hydraulic conductivities were guided by regularization observations to preferred conditions in areas that were insensitive to measurement observations (generally areas lacking observations). This approach is the Tikhonov regularization described by Doherty (2008).

The number of drawdown and recovery observations was reduced by averaging drawdowns from a well every 12 hours. Averaging reduced the number of measurement observations and suppressed high-frequency noise. Reliable drawdowns that were not affected by pumping losses, heating effects, or abridged records totaled 1,173 and were observed in 19 of 21 pumping-observation well pairs. Observation weights range from 0 to 14 . The two aquifer tests (MWP1 and MWP2) both use many of the same observation wells; thus, model calibration results will be discussed in terms of pumping-observation well pairs. A pumping-observation well pair is a given combination of one of the two pumping wells (Wells 4 and 10) and one of the observation wells from a given pumping well's test. Nine pumping-observation well pairs were assigned greater weights for observations occurring during water-level decline and the beginning of the water-level recovery observations. Lesser weights were assigned to the remaining water-level recovery observations as the drawdowns approach the detection limit. The nine pumping-observation well pairs with varied weights are the following: Wells 1,3 , and 17 with MWP1 pumping Well 4 and Wells $3,1,9,4,14$, and 11 with MWP2 pumping Well 10. Wells 6 and 12 were assigned zero weights because they are collocated with Wells 7 and 13 , respectively, and would effectively double the weight of the observation from this location if they were not assigned zero weights. Wells 7 and 13 are slightly deeper and therefore better represent the hydraulic properties of the Lahontan clays and silts. Only the last four water-level recovery observations for MWP2 pumping Well 10 are assigned weights because the large drawdowns in the pumping well are representative of an area much smaller than the $500 \mathrm{ft} \times 500 \mathrm{ft}$ model cell. All observations before the final four observations were assigned weights of zero. Compromised observations in wells that were affected by pumping well head losses and heating effects were assigned small weights so that hydraulic-conductivity estimates were minimally influenced.

Tikhonov regularization limited hydraulic-conductivity estimates at pilot points to reasonable values (Doherty and Johnston, 2003). Sharp differences between nearby values in similar hydrostratigraphic units were penalized to ensure relatively continuous and smooth hydraulic-conductivity distributions. Unrealistic hydraulic-conductivity distributions were avoided by limiting the fit between measured and simulated observations (Fienen and others, 2009). This irreducible, weighted measurement error is a combination of measurement and numerical model errors. 


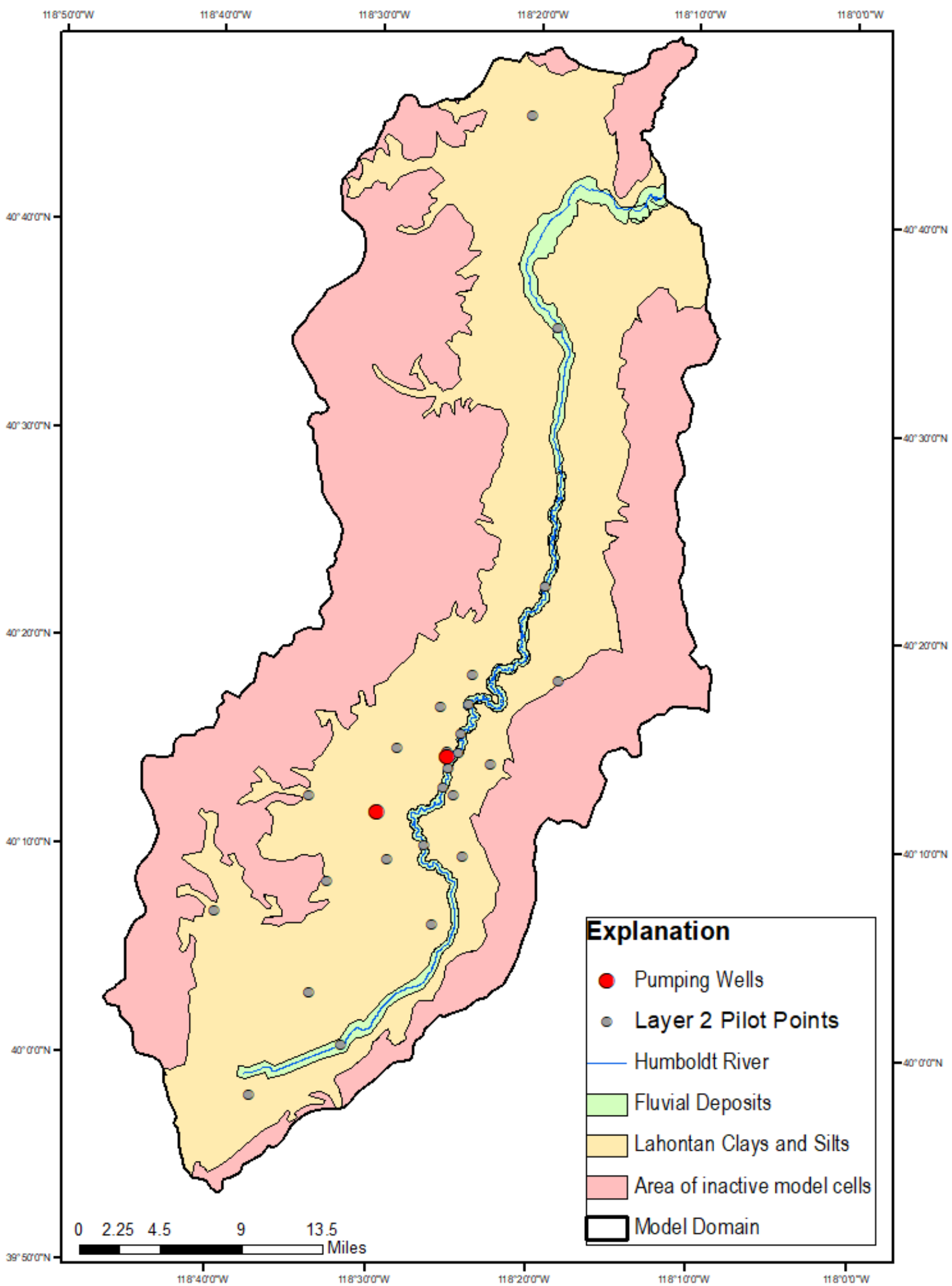

Figure 27. Zonation of conceptual model layer 2 for the lower Humboldt River Basin model. The Lahontan clays and silts zone is shown in tan, and the fluvial deposits zone is shown in green. Pilot points of conceptual model layer 2 are shown in grey. 


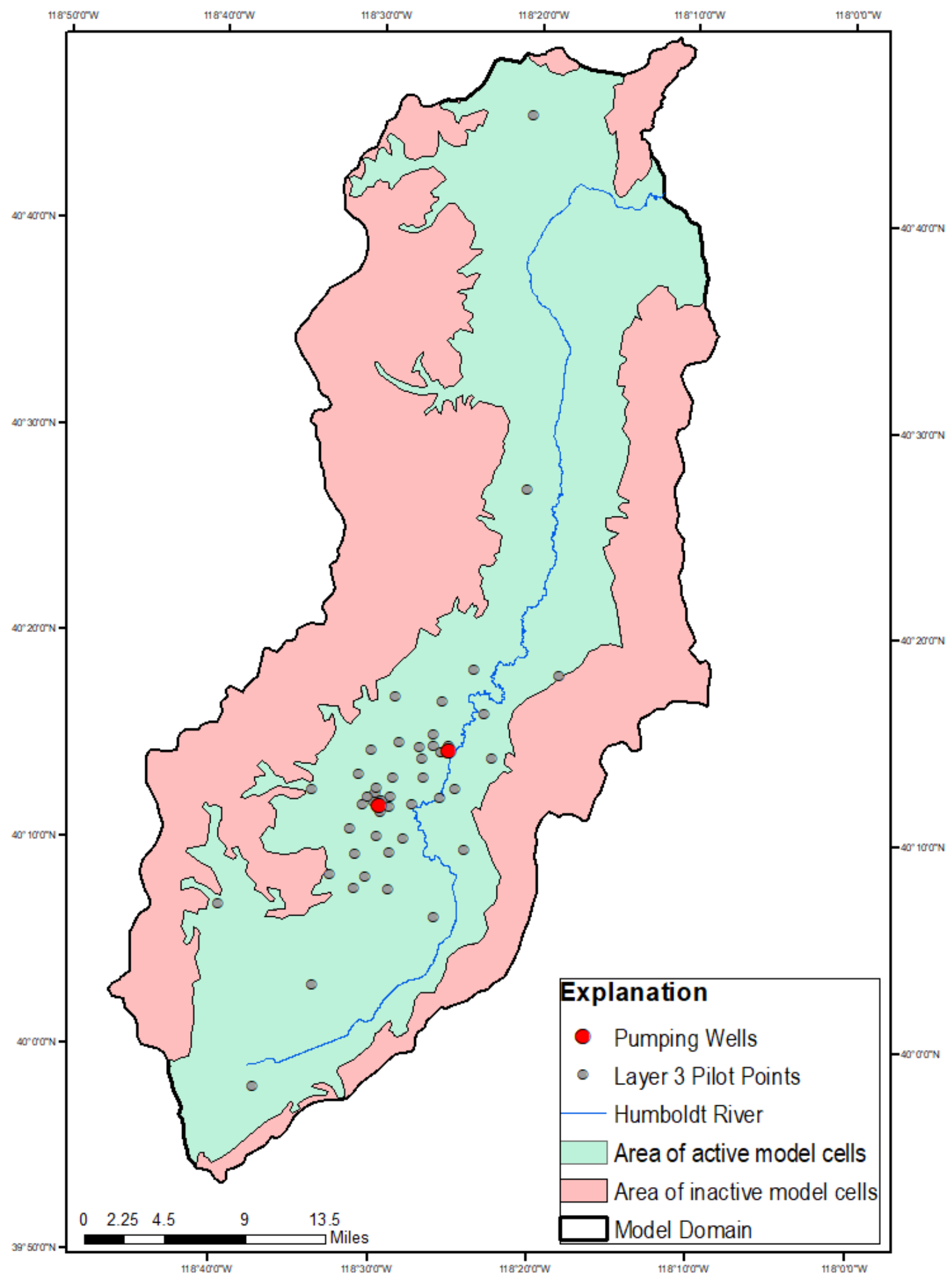

Figure 28. Pilot point distribution in layer 3 of the lower Humboldt River Basin model. 
Regularization observations were expressed using equations that defined preferred relations between hydraulicconductivity estimates. Regularization observations affected calibration most where the models were insensitive to measurement observations (common in regions lacking observations). Imposing preferred states, such as homogeneity, with regularization observations was preferable to rigid zones of assigned homogeneity. This was because hydraulicconductivity estimates could differ where dictated by observed drawdowns.

Root-mean-square error was used to gauge the misfit between simulated and measured drawdowns. The RMS error for the models was $0.04 \mathrm{ft}$. Simulated and measured drawdowns agreed, with RMS errors less than $0.04 \mathrm{ft}$ in 13 of the 21 pumping-observation well pairs. Differences between simulated and measured drawdowns in 20 pumpingobservation well pairs with unweighted RMS errors are shown in figures 29-48. The weighted RMS error values for all pumping-observation well pairs are listed in table 7. Simulated spatial drawdowns for each multi-well pumping test are shown in figure 49.

The simulated results from the MWP2 model of Well 9 overestimate total drawdown and underestimate recovery (fig. 40). Well 9 is located near the likely boundary of lowpermeability consolidated rocks, which are represented as a no-flow boundary in MODFLOW. This boundary may actually be leaky, but because it is represented as a strictly no-flow boundary, the simulated drawdown is overestimated (Barlow and Leake, 2012).
Table 7. Weighted RMS error values for all pumping-observation well pairs in Lovelock Valley, Nevada.

[ft, foot; RMS, root-mean-square]

\begin{tabular}{ccc}
\hline Well & Aquifer test & $\begin{array}{c}\text { Weighted RMS error } \\
\text { (ft) }\end{array}$ \\
\hline 1 & Multi-well pumping test \#1 & 0.710 \\
2 & Multi-well pumping test \#1 & 0.610 \\
3 & Multi-well pumping test \#1 & 0.033 \\
8 & Multi-well pumping test \#1 & 0.021 \\
10 & Multi-well pumping test \#1 & 0.092 \\
17 & Multi-well pumping test \#1 & 0.000 \\
1 & Multi-well pumping test \#2 & 0.036 \\
3 & Multi-well pumping test \#2 & 0.025 \\
4 & Multi-well pumping test \#2 & 0.077 \\
6 & Multi-well pumping test \#2 & 0.000 \\
7 & Multi-well pumping test \#2 & 0.036 \\
8 & Multi-well pumping test \#2 & 0.007 \\
9 & Multi-well pumping test \#2 & 0.600 \\
10 & Multi-well pumping test \#2 & 2.247 \\
11 & Multi-well pumping test \#2 & 0.303 \\
12 & Multi-well pumping test \#2 & 0.000 \\
13 & Multi-well pumping test \#2 & 0.021 \\
14 & Multi-well pumping test \#2 & 0.082 \\
15 & Multi-well pumping test \#2 & 0.012 \\
16 & Multi-well pumping test \#2 & 0.018 \\
17 & Multi-well pumping test \#2 & 0.000 \\
\hline
\end{tabular}




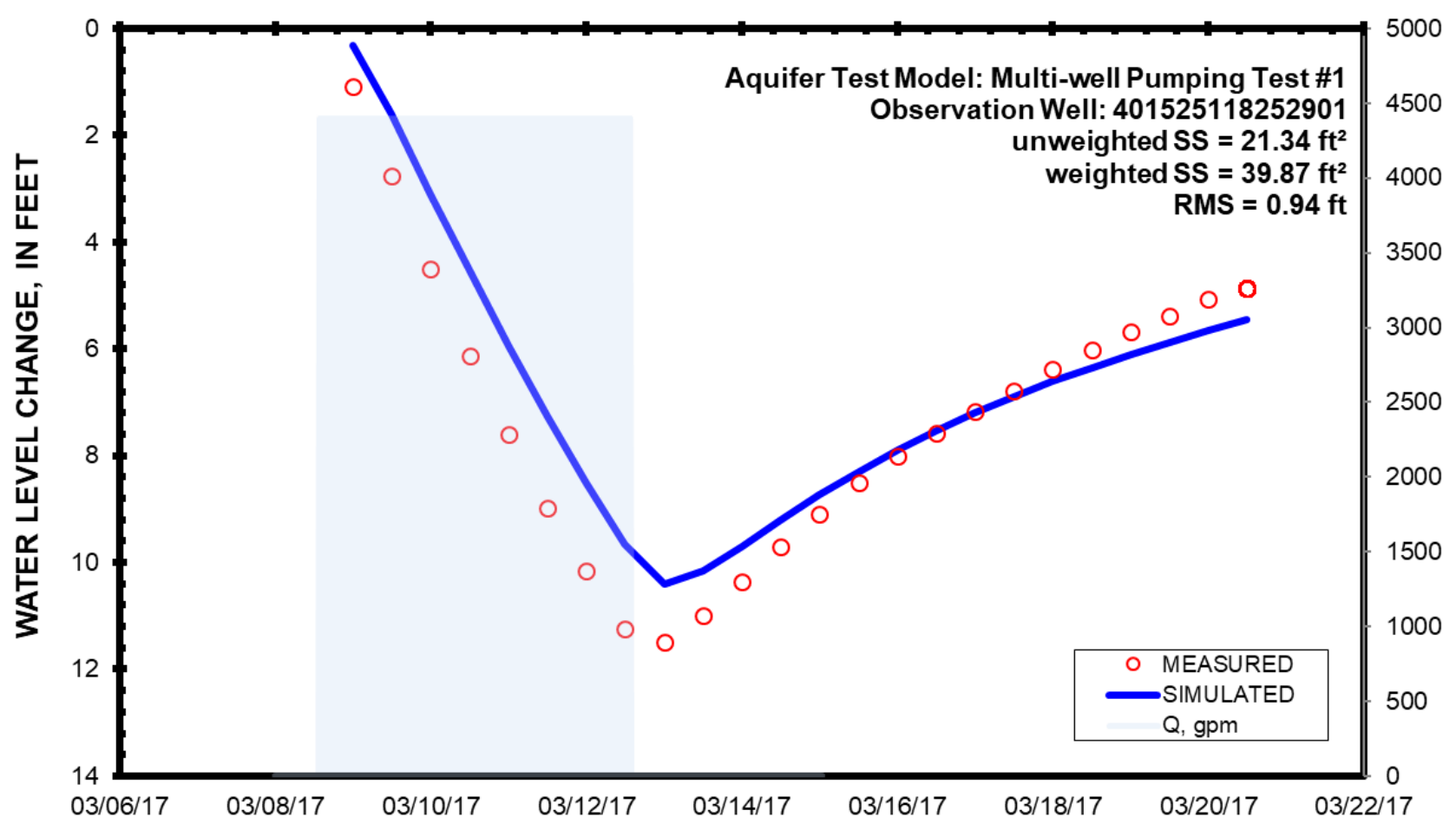

Figure 29. Simulated versus observed drawdown during multi-well pumping test \#1 (MWP1) for Well 1, located 1.2 miles from the pumping well in Lovelock Valley, Nevada. Pumping well discharge (0) in gallons per minute ( $\mathrm{gpm}$ ) is represented with the secondary $\mathrm{y}$-axis. [ft, foot; $\mathrm{ft}^{2}$, square foot; gpm, gallon per minute; SS, sum of square errors; RMS, root mean square error]

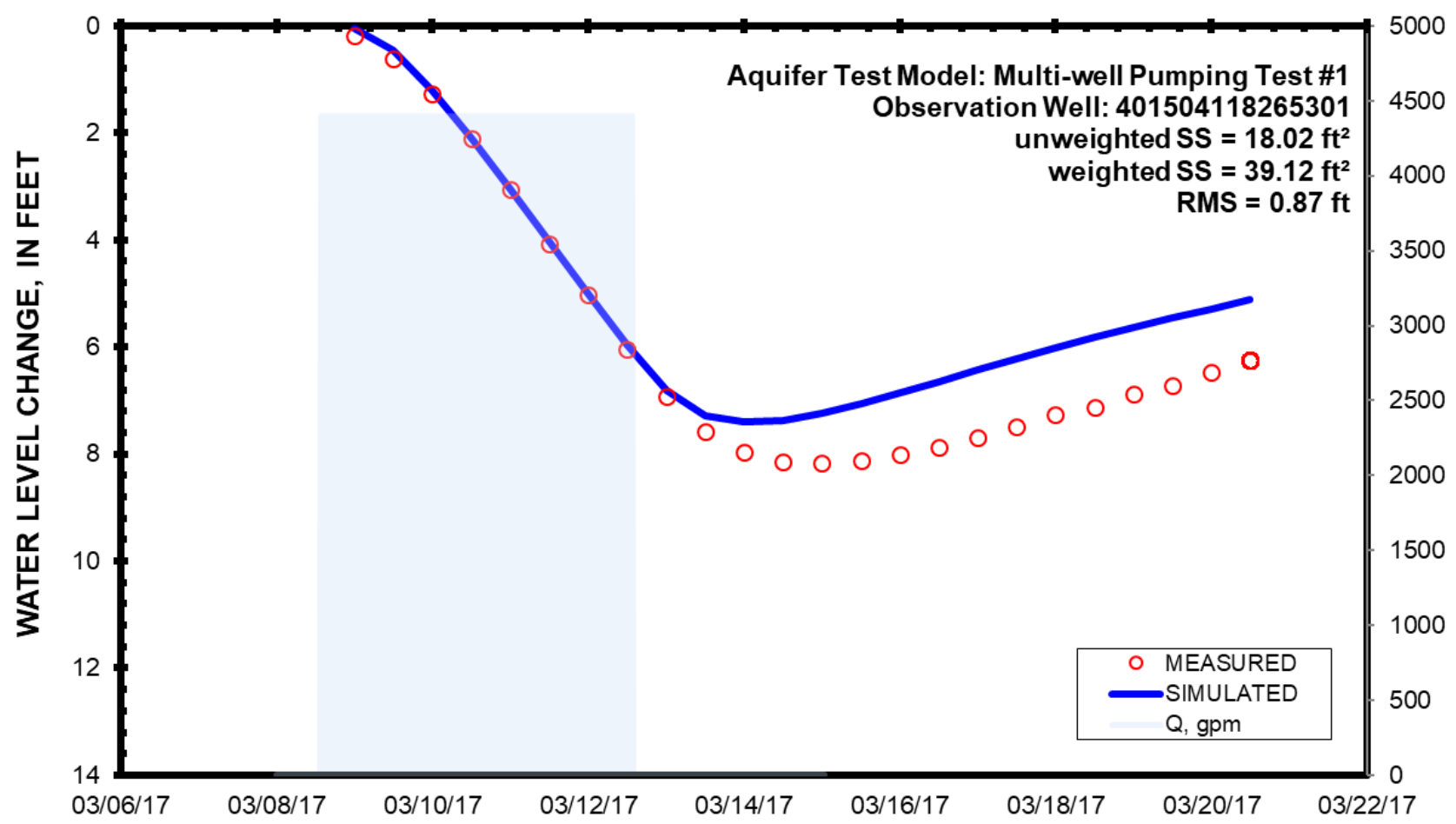

Figure 30. Simulated versus observed drawdown during multi-well pumping test \#1 (MWP1) for Well 2, located 1.5 miles from the pumping well in Lovelock Valley, Nevada. Pumping well discharge (0) in gallons per minute (gpm) is represented with the secondary $\mathrm{y}$-axis. [ft, foot; $\mathrm{ft}^{2}$, square foot; gpm, gallon per minute; SS, sum of square errors; RMS, root mean square error] 


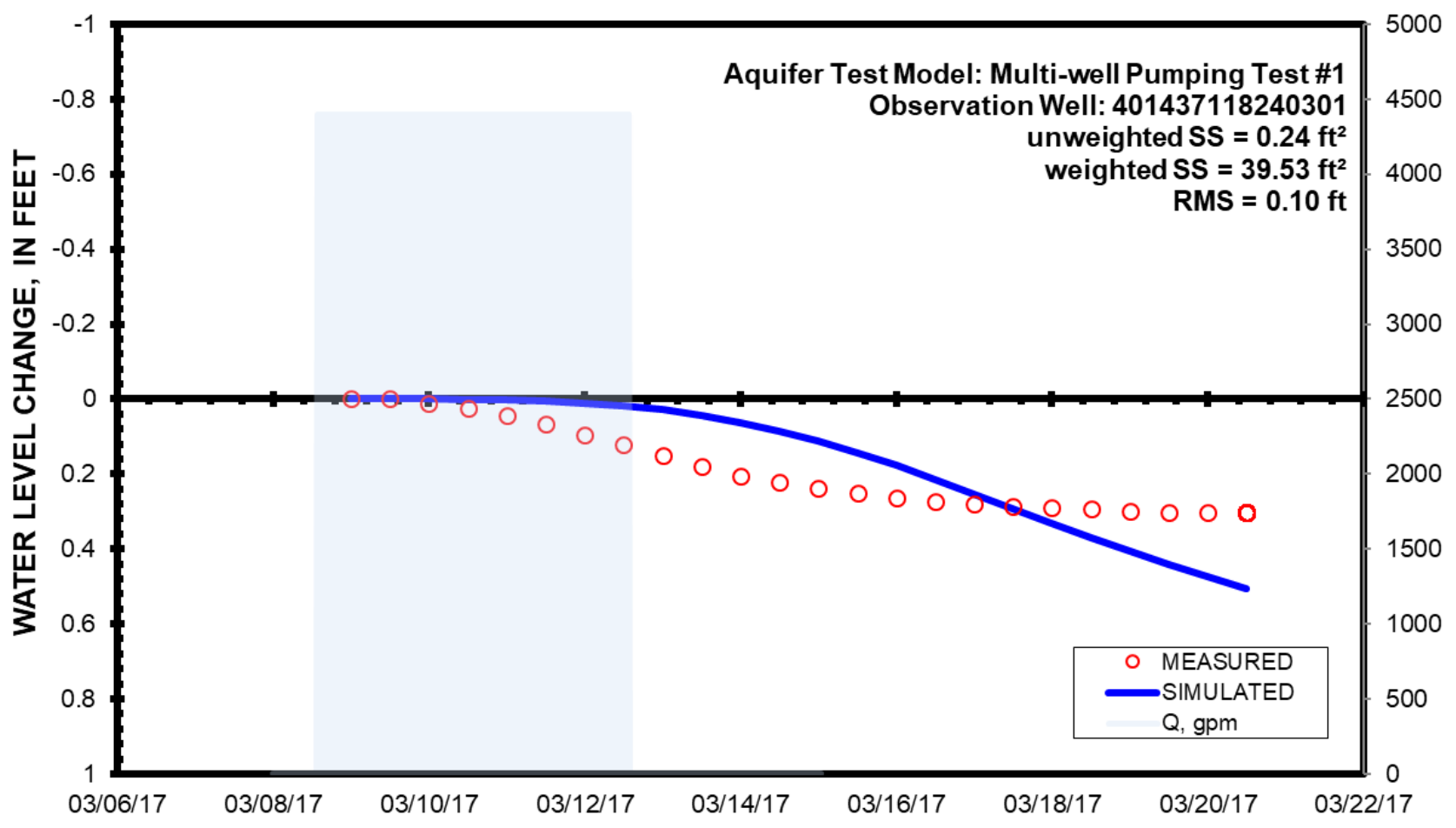

Figure 31. Simulated versus observed drawdown during multi-well pumping test \#1 (MWP1) for Well 3 , located 1.2 miles from the pumping well in Lovelock Valley, Nevada. Pumping well discharge (0) in gallons per minute (gpm) is represented with the secondary $\mathrm{y}$-axis. [ft, foot; $\mathrm{ft}^{2}$, square foot; gpm, gallon per minute; SS, sum of square errors; RMS, root mean square error]

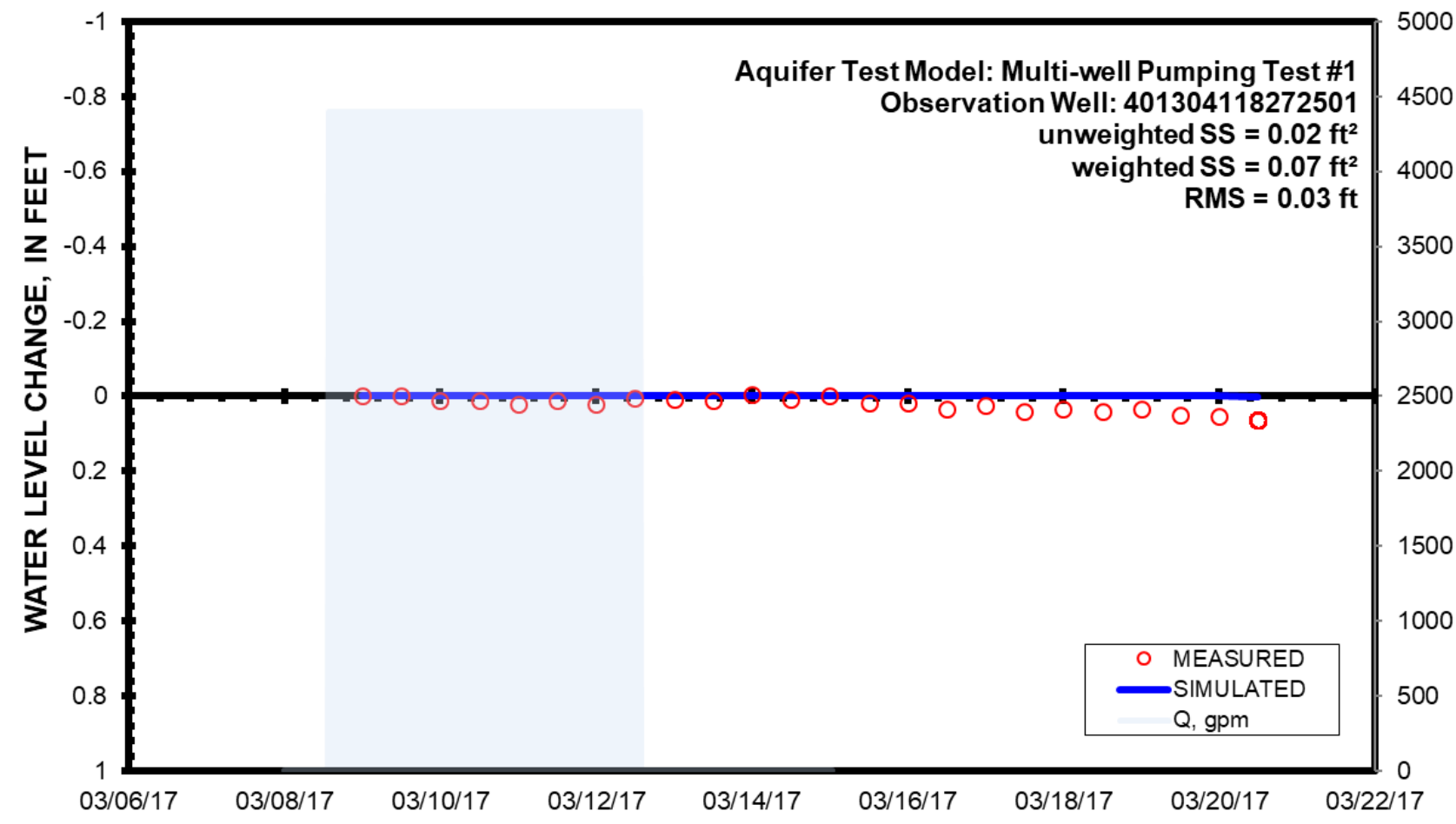

Figure 32. Simulated versus observed drawdown during multi-well pumping test \#1 (MWP1) for Well 8, located 2.4 miles from the pumping well in Lovelock Valley, Nevada. Pumping well discharge $(0)$ in gallons per minute $(\mathrm{gpm})$ is represented with the secondary $\mathrm{y}$-axis. [ft, foot; $\mathrm{ft}^{2}$, square foot; gpm, gallon per minute; SS, sum of square errors; RMS, root mean square error] 


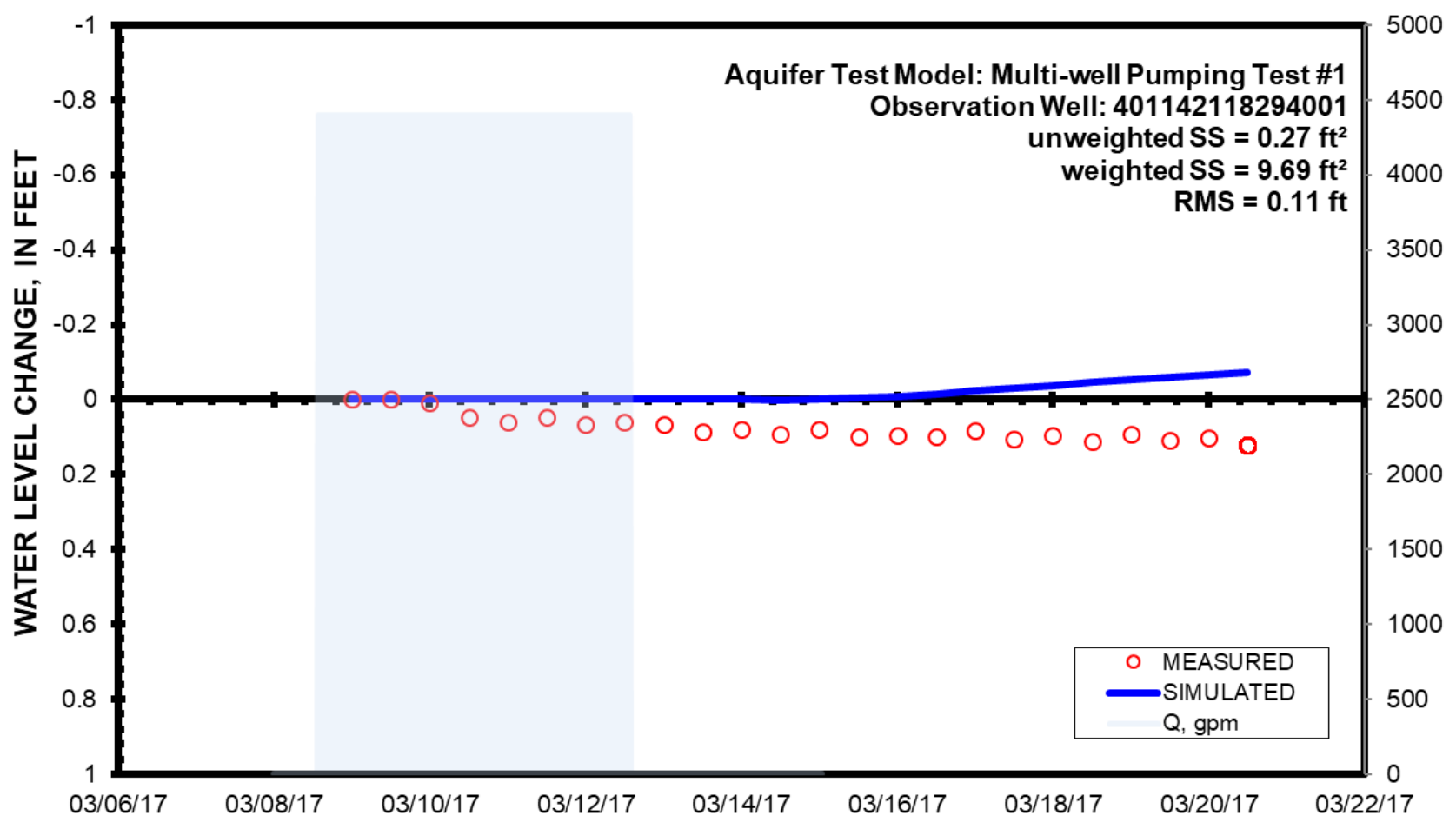

Figure 33. Simulated versus observed drawdown during multi-well pumping test \#1 (MWP1) for Well 10, located 5.0 miles from the pumping well in Lovelock Valley, Nevada. Pumping well discharge (0) in gallons per minute ( $\mathrm{gpm}$ ) is represented with the secondary $\mathrm{y}$-axis. [ft, foot; $\mathrm{ft}^{2}$, square foot; gpm, gallon per minute; SS, sum of square errors; RMS, root mean square error]

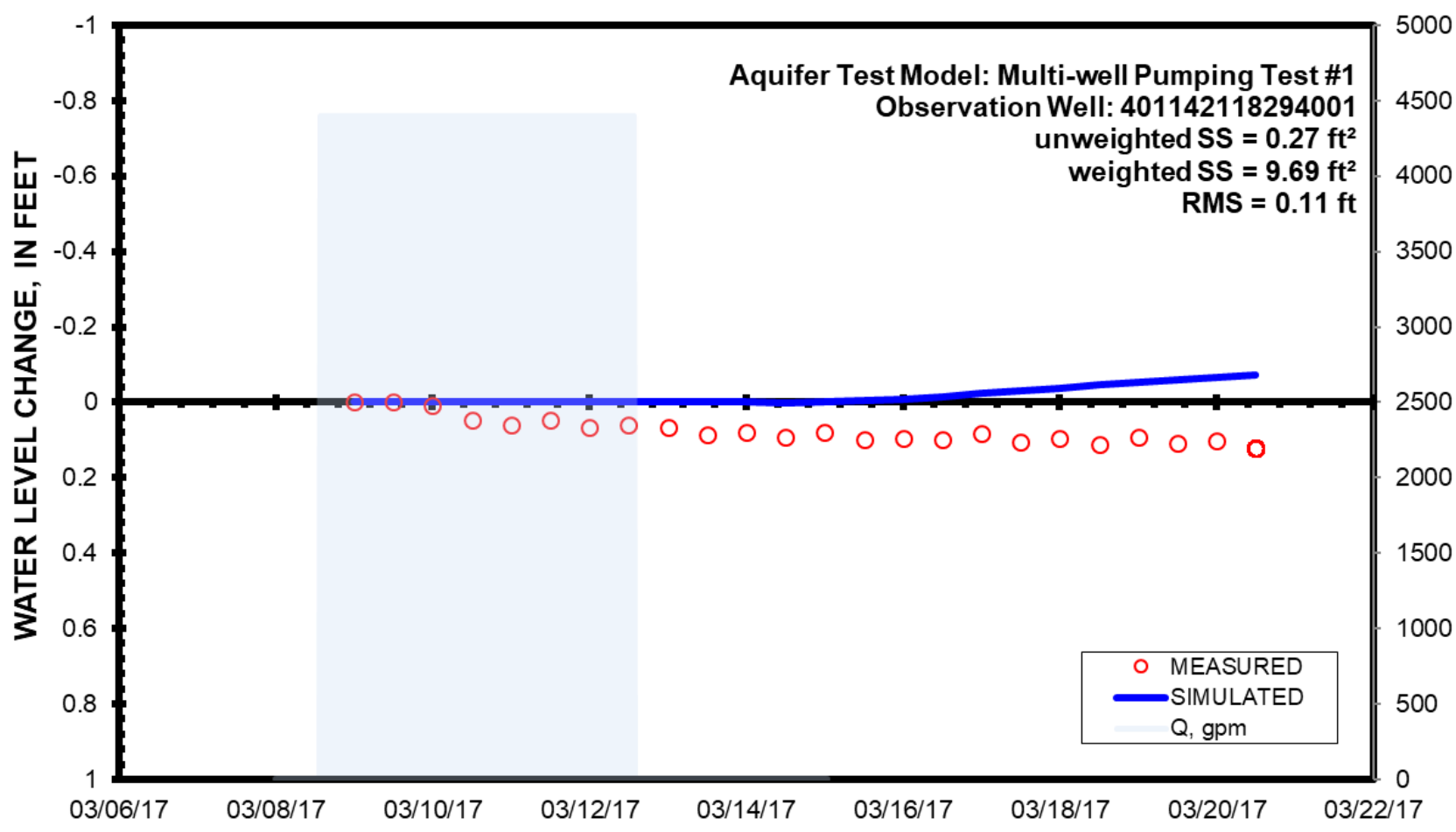

Figure 34. Simulated versus observed drawdown during multi-well pumping test \#1 (MWP1) for Well 10, located 5.0 miles from the pumping well in Lovelock Valley, Nevada. Pumping well discharge $(0)$ in gallons per minute $(\mathrm{gpm})$ is represented with the secondary $\mathrm{y}$-axis. [ft, foot; $\mathrm{ft}^{2}$, square foot; gpm, gallon per minute; SS, sum of square errors; RMS, root mean square error] 


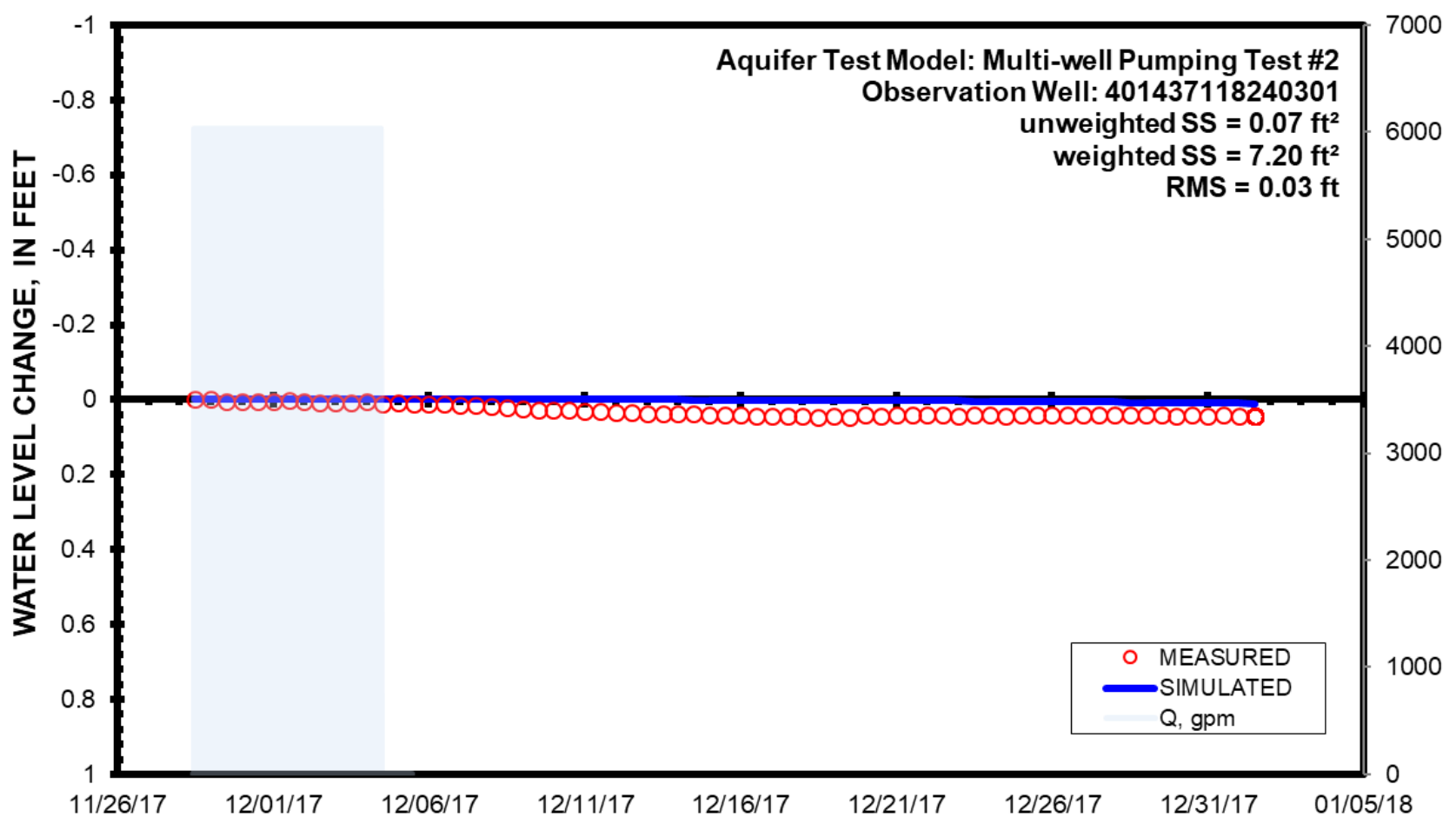

Figure 35. Simulated versus observed drawdown during multi-well pumping test \#2 (MWP2) for Well 3, located 6.0 miles from the pumping well in Lovelock Valley, Nevada. Pumping well discharge (0) in gallons per minute (gpm) is represented with the secondary $\mathrm{y}$-axis. [ft, foot; $\mathrm{ft}^{2}$, square foot; gpm, gallon per minute; SS, sum of square errors; RMS, root mean square error]

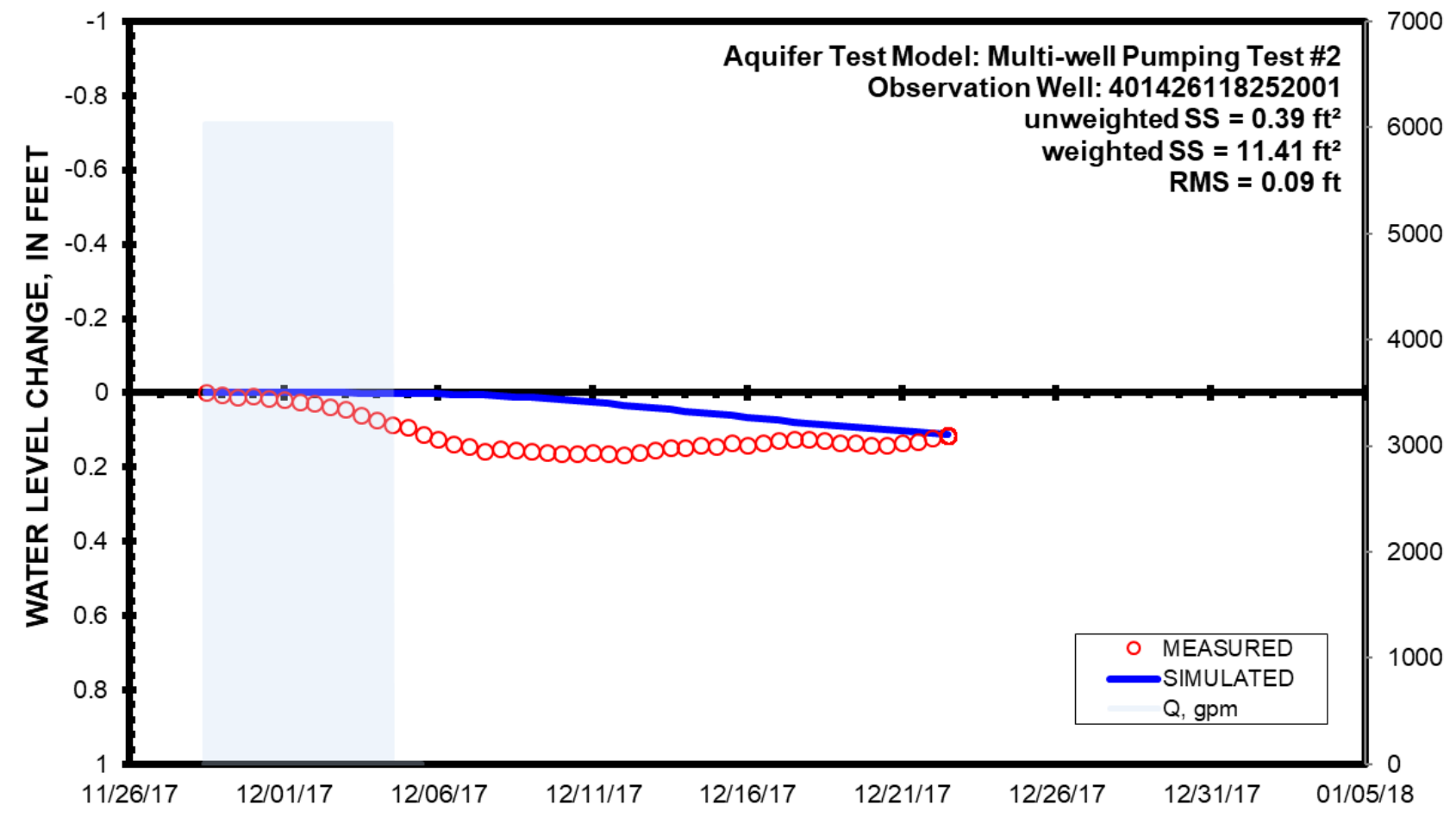

Figure 36. Simulated versus observed drawdown during multi-well pumping test \#2 (MWP2) for Well 4, located 5.0 miles from the pumping well in Lovelock Valley, Nevada. Pumping well discharge (0) in gallons per minute (gpm) is represented with the secondary $\mathrm{y}$-axis. [ft, foot; $\mathrm{ft}^{2}$, square foot; gpm, gallon per minute; SS, sum of square errors; RMS, root mean square error] 


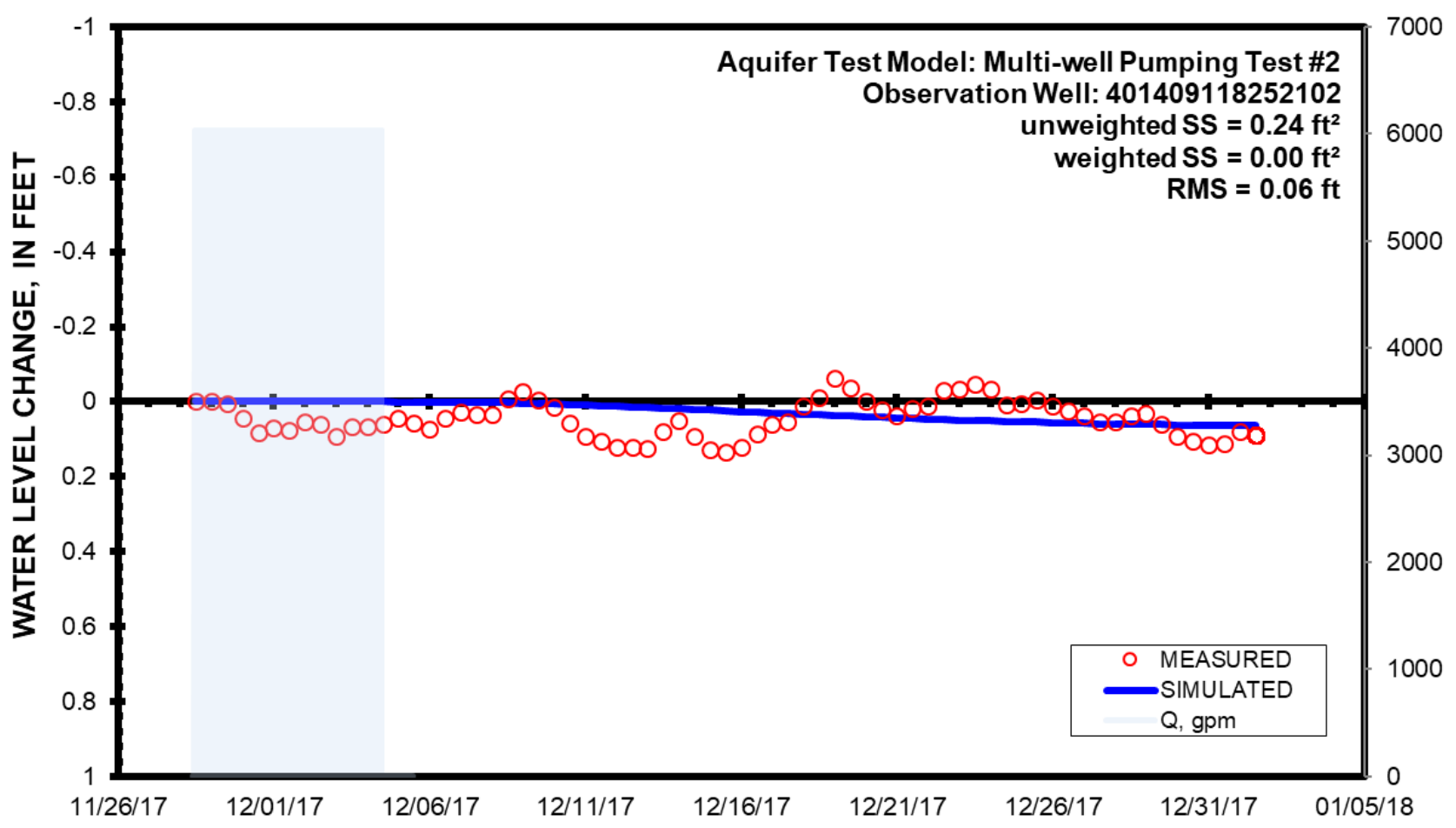

Figure 37. Simulated versus observed drawdown during multi-well pumping test \#2 (MWP2) for Well 6, located 4.8 miles from the pumping well in Lovelock Valley, Nevada. Pumping well discharge (0) in gallons per minute ( $\mathrm{gpm}$ ) is represented with the secondary $\mathrm{y}$-axis. [ft, foot; $\mathrm{ft}^{2}$, square foot; gpm, gallon per minute; SS, sum of square errors; RMS, root mean square error]

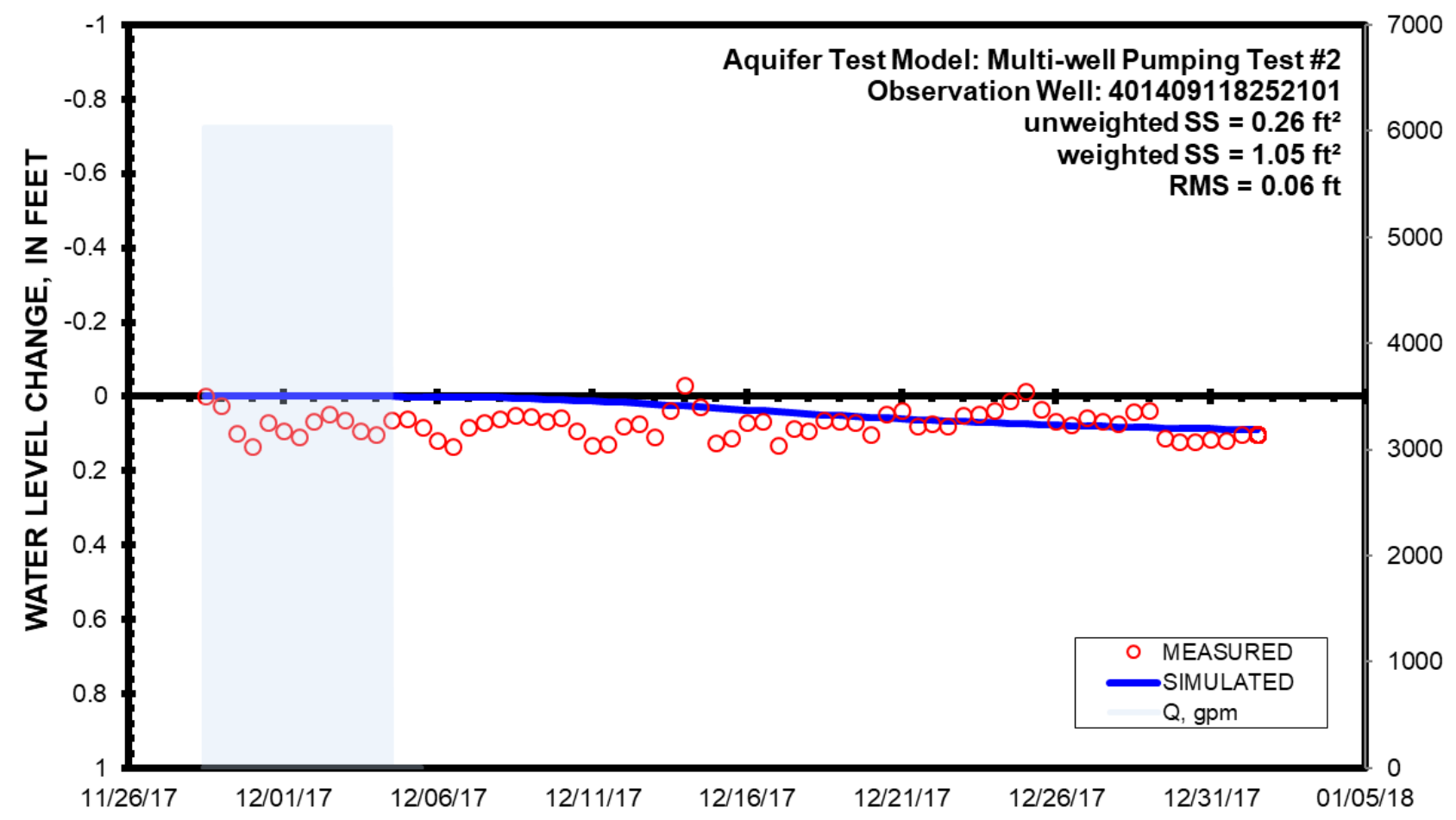

Figure 38. Simulated versus observed drawdown during multi-well pumping test \#2 (MWP2) for Well 7, located 4.8 miles from the pumping well in Lovelock Valley, Nevada. Pumping well discharge (0) in gallons per minute (gpm) is represented with the secondary $\mathrm{y}$-axis. [ft, foot; $\mathrm{ft}^{2}$, square foot; gpm, gallon per minute; SS, sum of square errors; RMS, root mean square error] 


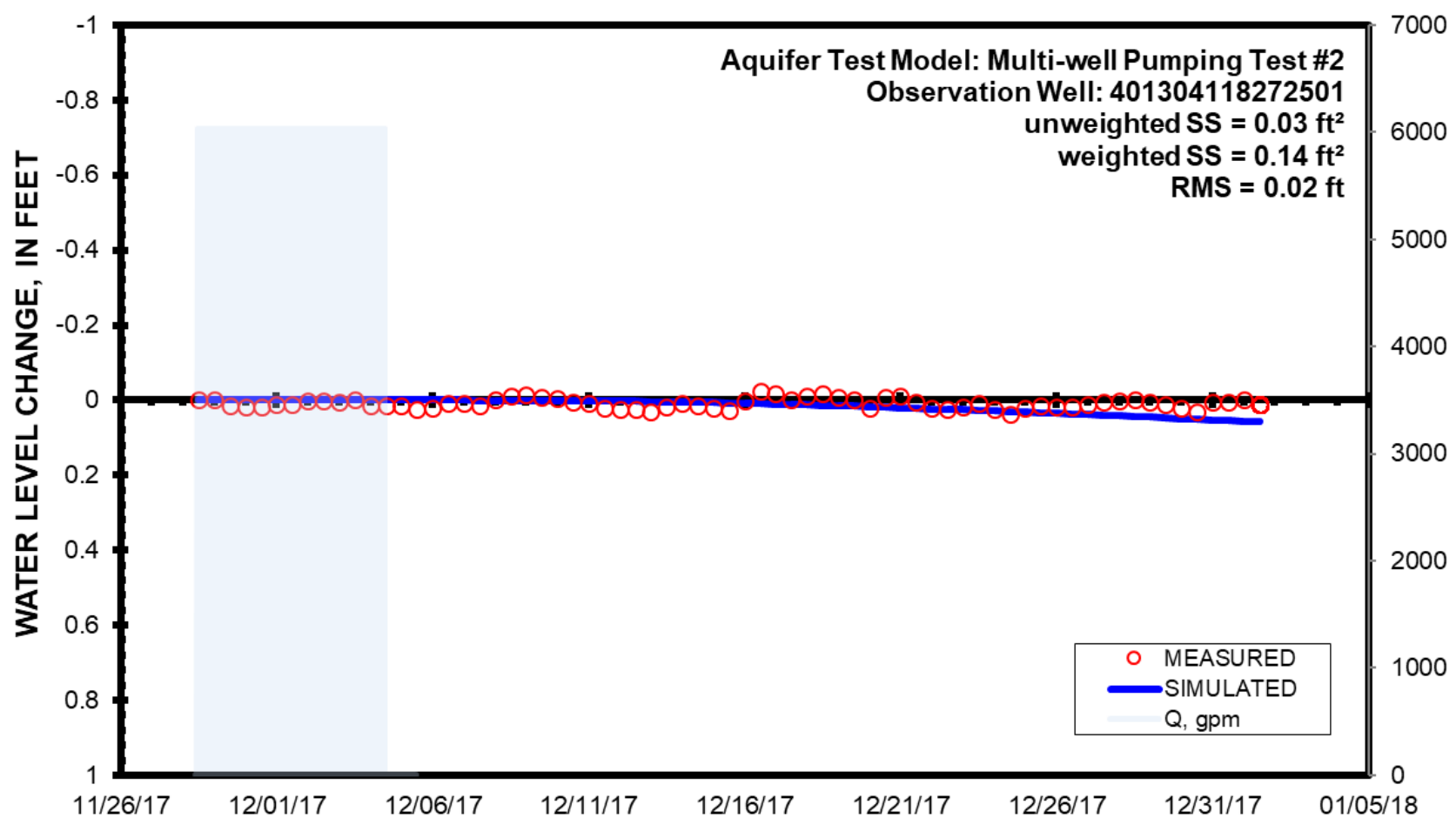

Figure 39. Simulated versus observed drawdown during multi-well pumping test \#2 (MWP2) for Well 8, located 2.6 miles from the pumping well in Lovelock Valley, Nevada. Pumping well discharge (0) in gallons per minute (gpm) is represented with the secondary $\mathrm{y}$-axis. [ft, foot; $\mathrm{ft}^{2}$, square foot; gpm, gallon per minute; SS, sum of square errors; RMS, root mean square error]

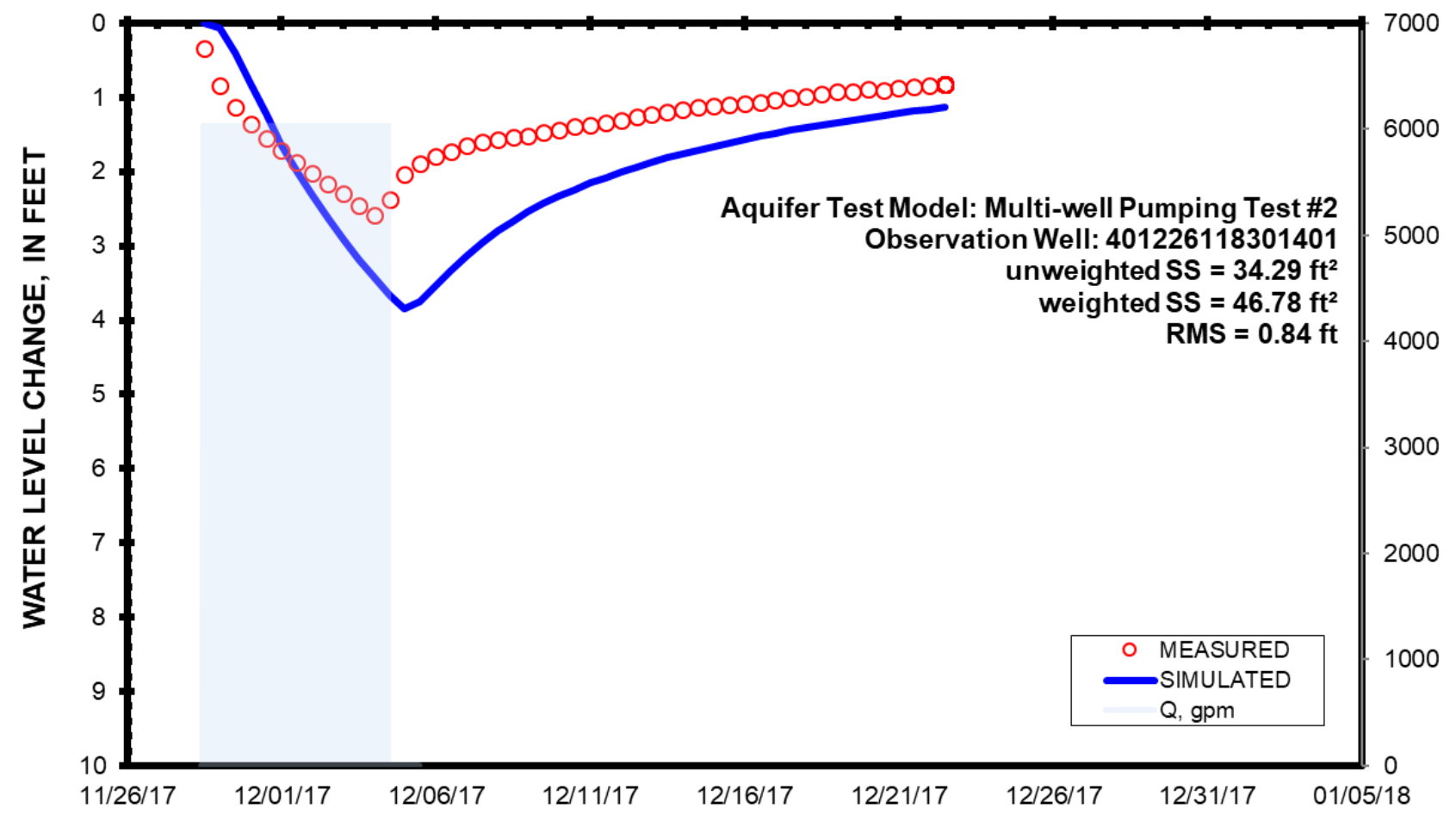

Figure 40. Simulated versus observed drawdown during multi-well pumping test \#2 (MWP2) for Well 9, located 1.0 miles from the pumping well in Lovelock Valley, Nevada. Pumping well discharge (0) in gallons per minute (gpm) is represented with the secondary $\mathrm{y}$-axis. [ft, foot; $\mathrm{ft}^{2}$, square foot; gpm, gallon per minute; SS, sum of square errors; RMS, root mean square error] 


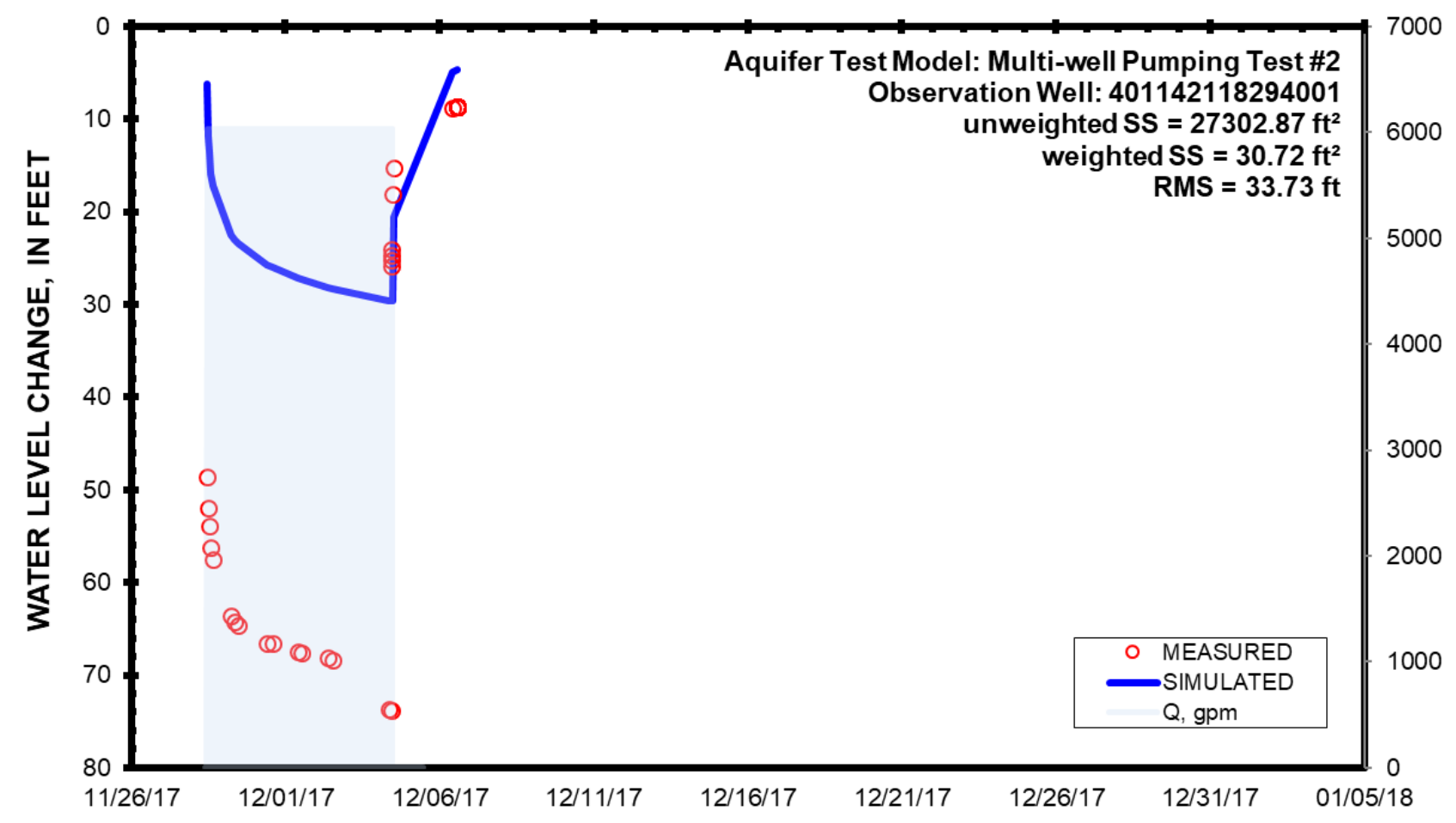

Figure 41. Simulated versus observed drawdown during multi-well pumping test \#2 (MWP2) for Well 10, the pumping well, in Lovelock Valley, Nevada. Pumping well discharge $(0)$ in gallons per minute $(\mathrm{gpm})$ is represented with the secondary $\mathrm{y}$-axis. [ft, foot; $\mathrm{ft}^{2}$, square foot; gpm, gallon per minute; SS, sum of square errors; RMS, root mean square error]

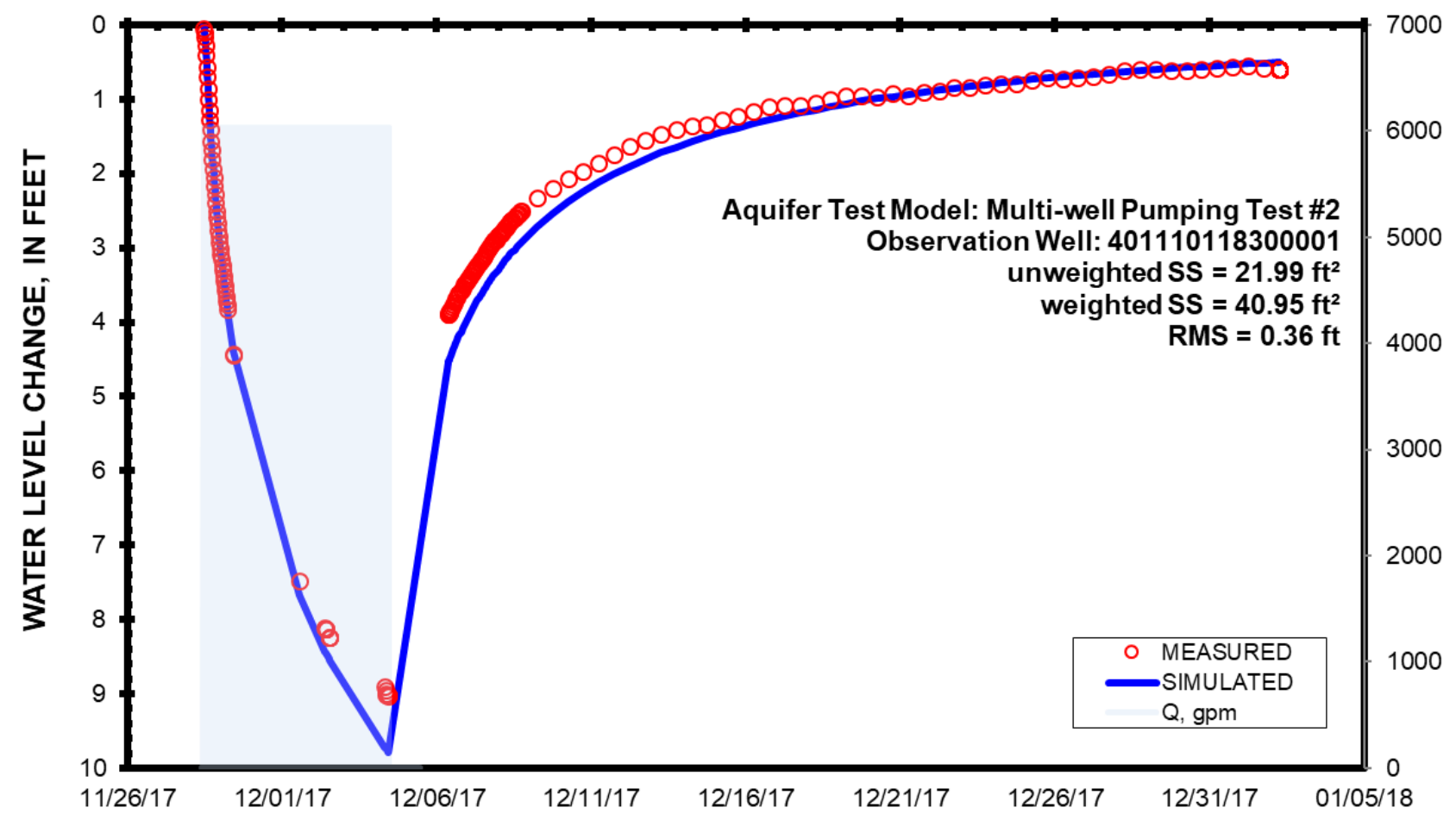

Figure 42. Simulated versus observed drawdown during multi-well pumping test \#2 (MWP2) for Well 11, located 0.6 miles from the pumping well in Lovelock Valley, Nevada. Pumping well discharge $(0)$ in gallons per minute $(\mathrm{gpm})$ is represented with the secondary $\mathrm{y}$-axis. [ft, foot; $\mathrm{ft}^{2}$, square foot; gpm, gallon per minute; SS, sum of square errors; RMS, root mean square error] 


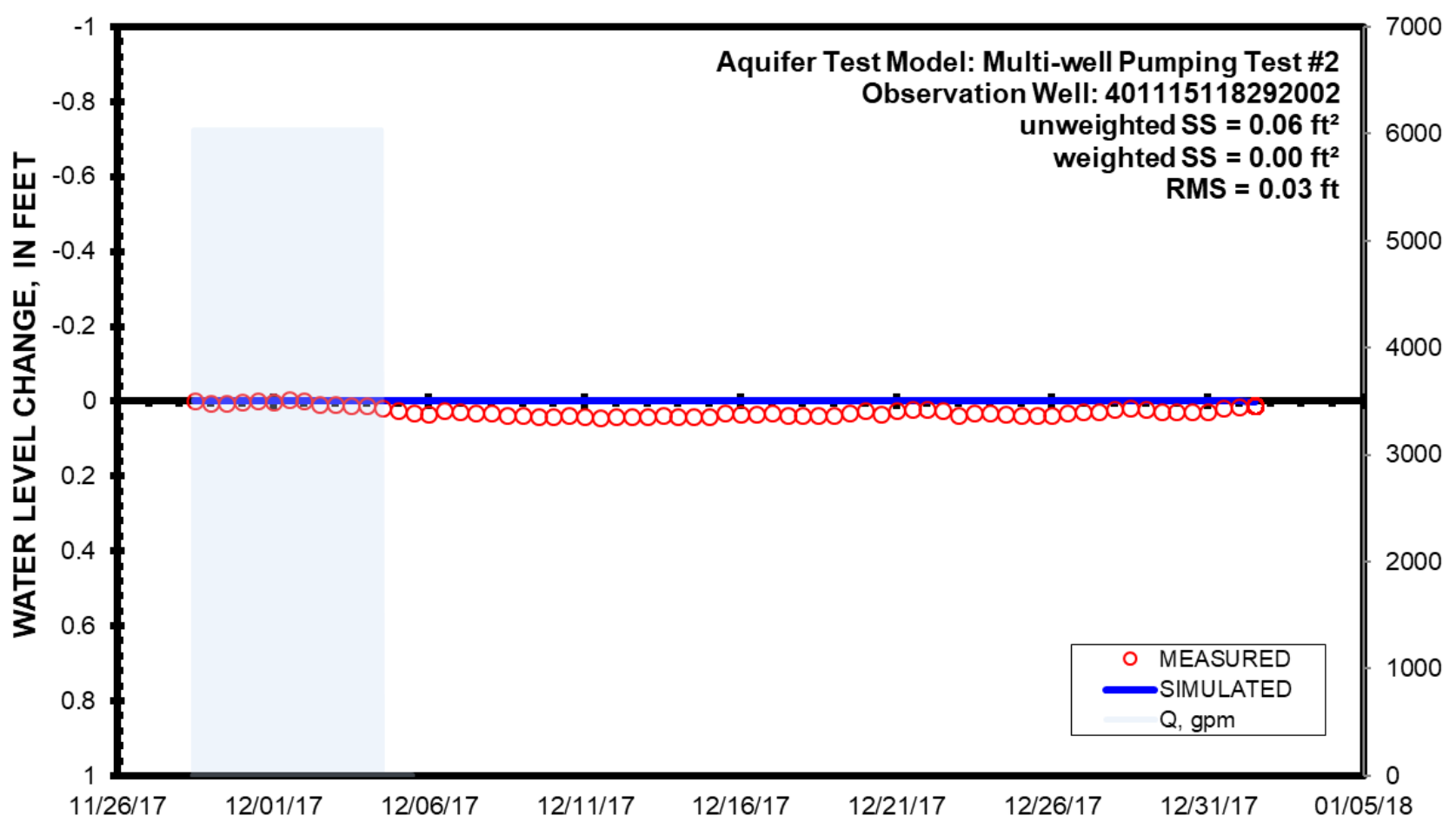

Figure 43. Simulated versus observed drawdown during multi-well pumping test \#2 (MWP2) for Well 12, located 0.6 miles from the pumping well in Lovelock Valley, Nevada. Pumping well discharge (0) in gallons per minute (gpm) is represented with the secondary $\mathrm{y}$-axis. [ft, foot; $\mathrm{ft}^{2}$, square foot; gpm, gallon per minute; SS, sum of square errors; RMS, root mean square error]

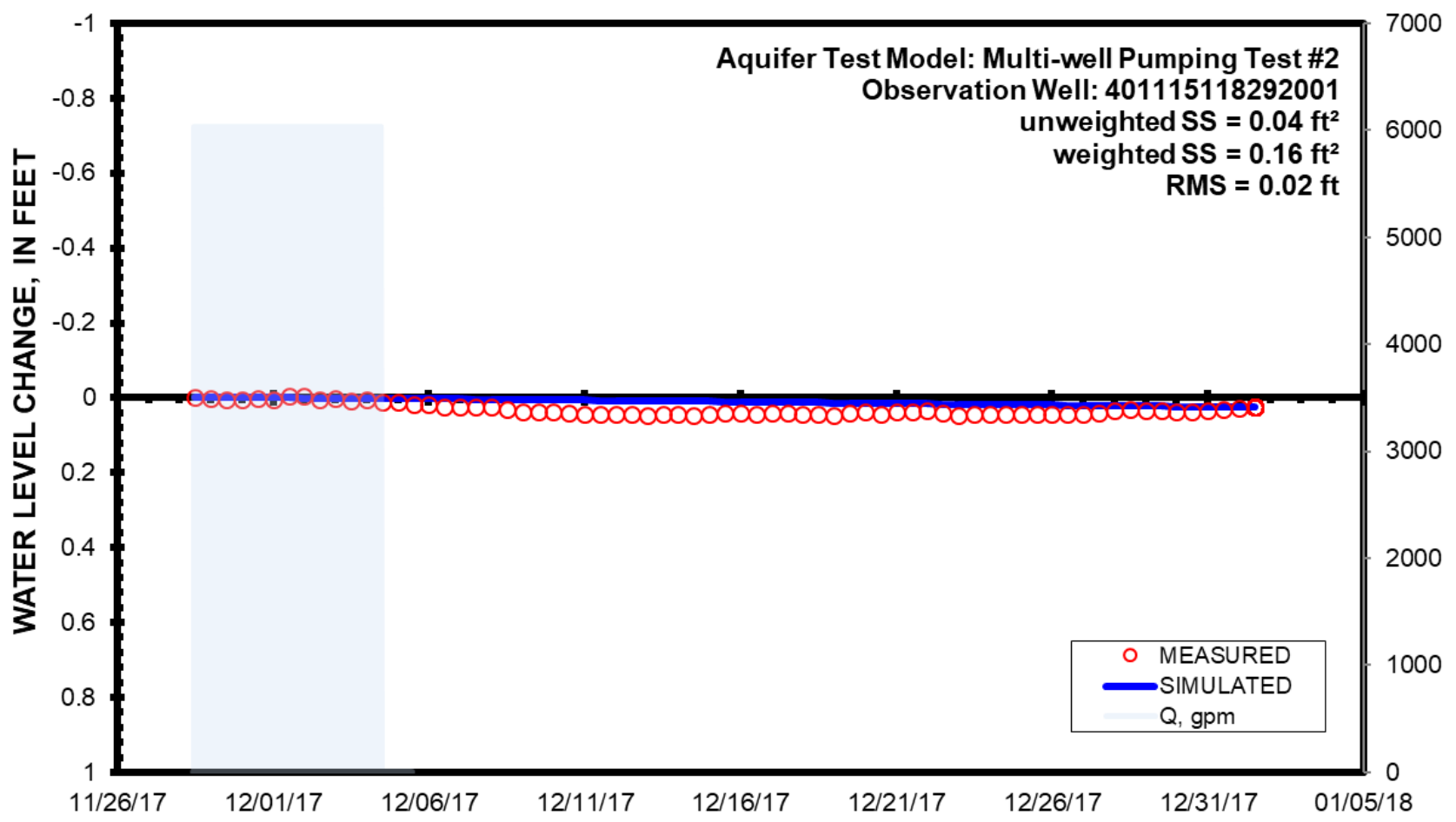

Figure 44. Simulated versus observed drawdown during multi-well pumping test \#2 (MWP2) for Well 13, located 0.6 miles from the pumping well in Lovelock Valley, Nevada. Pumping well discharge (0) in gallons per minute (gpm) is represented with the secondary $\mathrm{y}$-axis. [ft, foot; $\mathrm{ft}^{2}$, square foot; gpm, gallon per minute; SS, sum of square errors; RMS, root mean square error] 


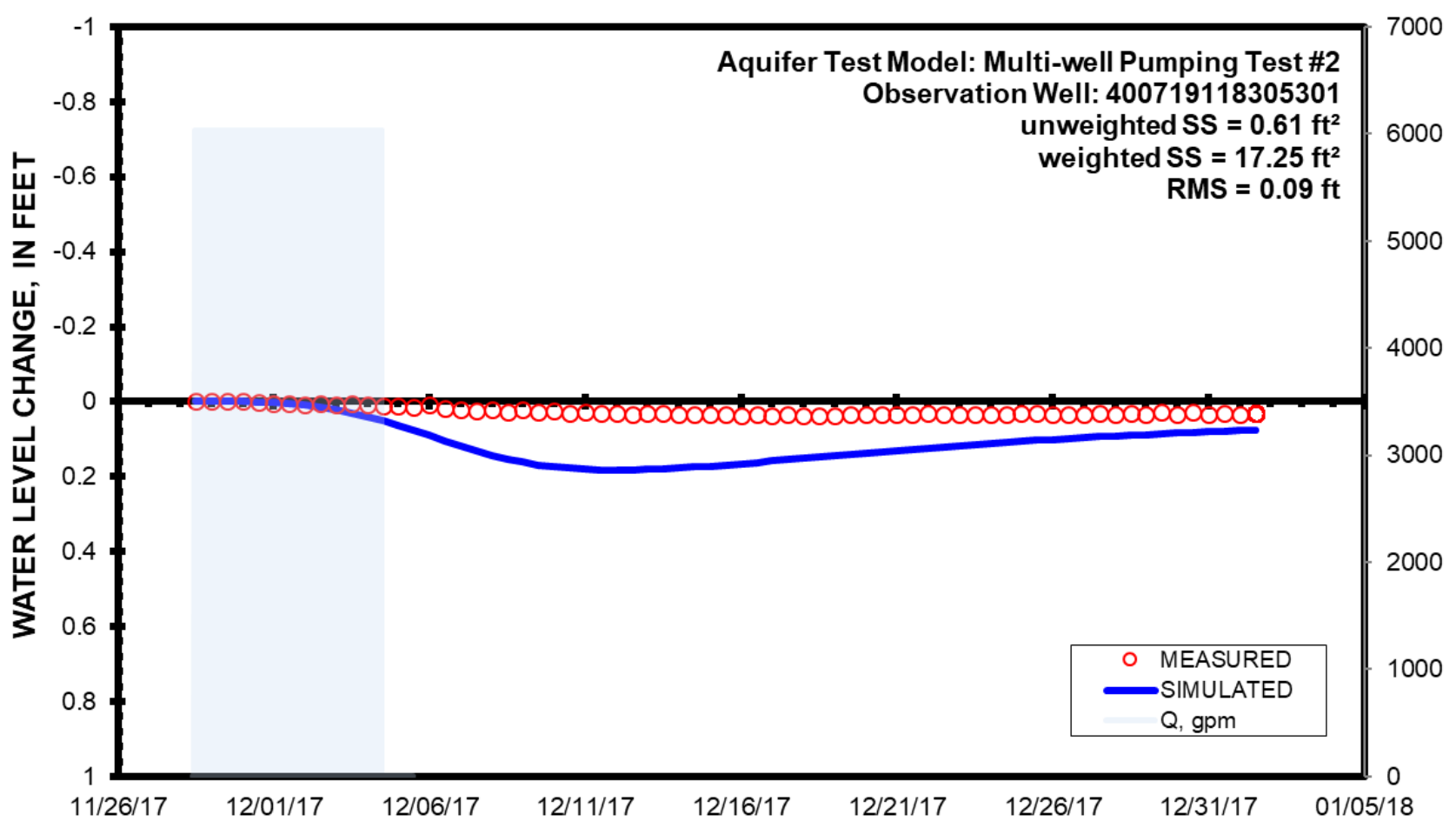

Figure 45. Simulated versus observed drawdown during multi-well pumping test \#2 (MWP2) for Well 14, located 5.1 miles from the pumping well in Lovelock Valley, Nevada. Pumping well discharge (0) in gallons per minute ( $\mathrm{gpm}$ ) is represented with the secondary $\mathrm{y}$-axis. [ft, foot; $\mathrm{ft}^{2}$, square foot; gpm, gallon per minute; SS, sum of square errors; RMS, root mean square error]

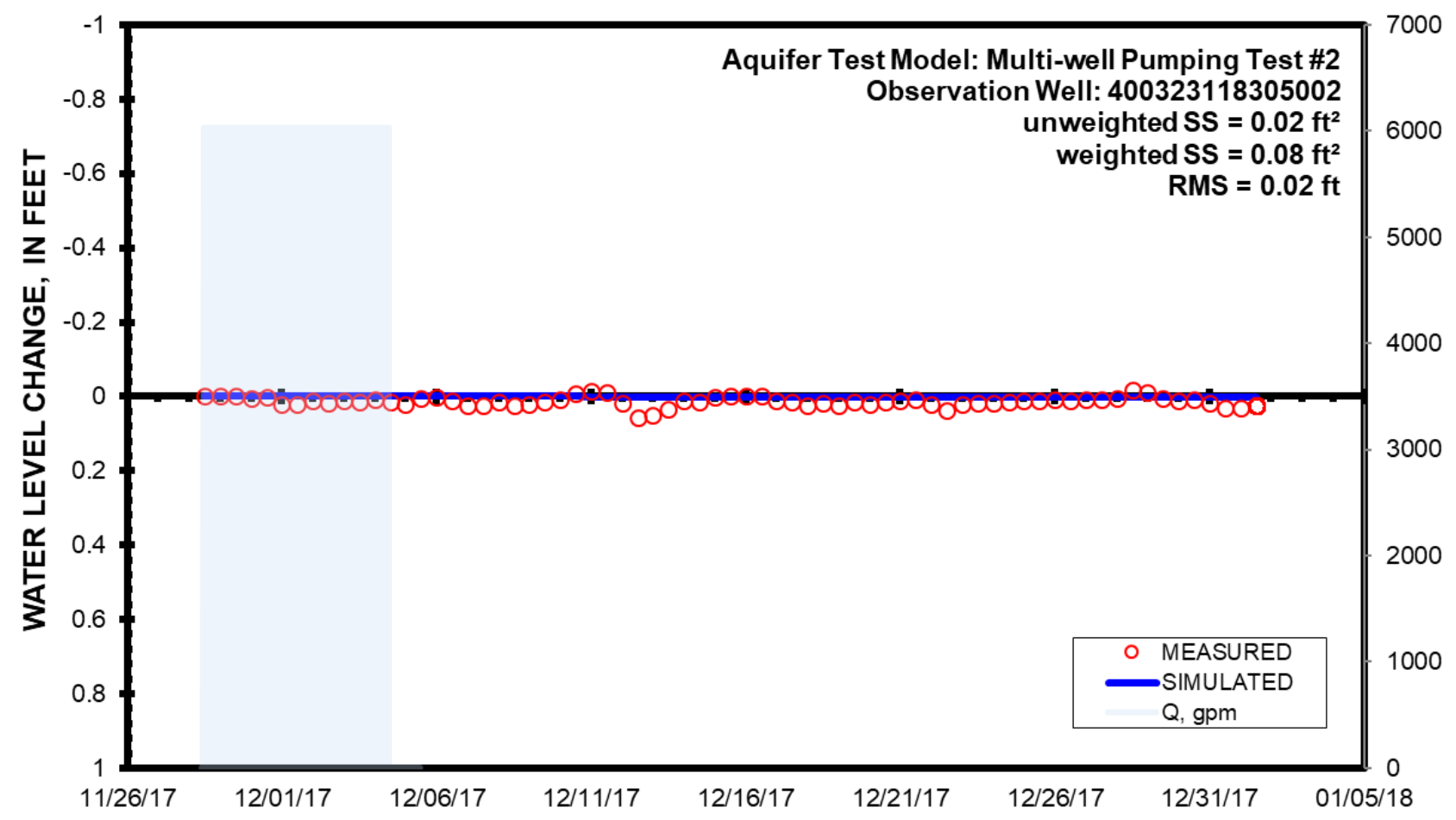

Figure 46. Simulated versus observed drawdown during multi-well pumping test \#2 (MWP2) for Well 15, located 9.6 miles from the pumping well in Lovelock Valley, Nevada. Pumping well discharge (0) in gallons per minute (gpm) is represented with the secondary $\mathrm{y}$-axis. [ft, foot; $\mathrm{ft}^{2}$, square foot; gpm, gallon per minute; SS, sum of square errors; RMS, root mean square error] 


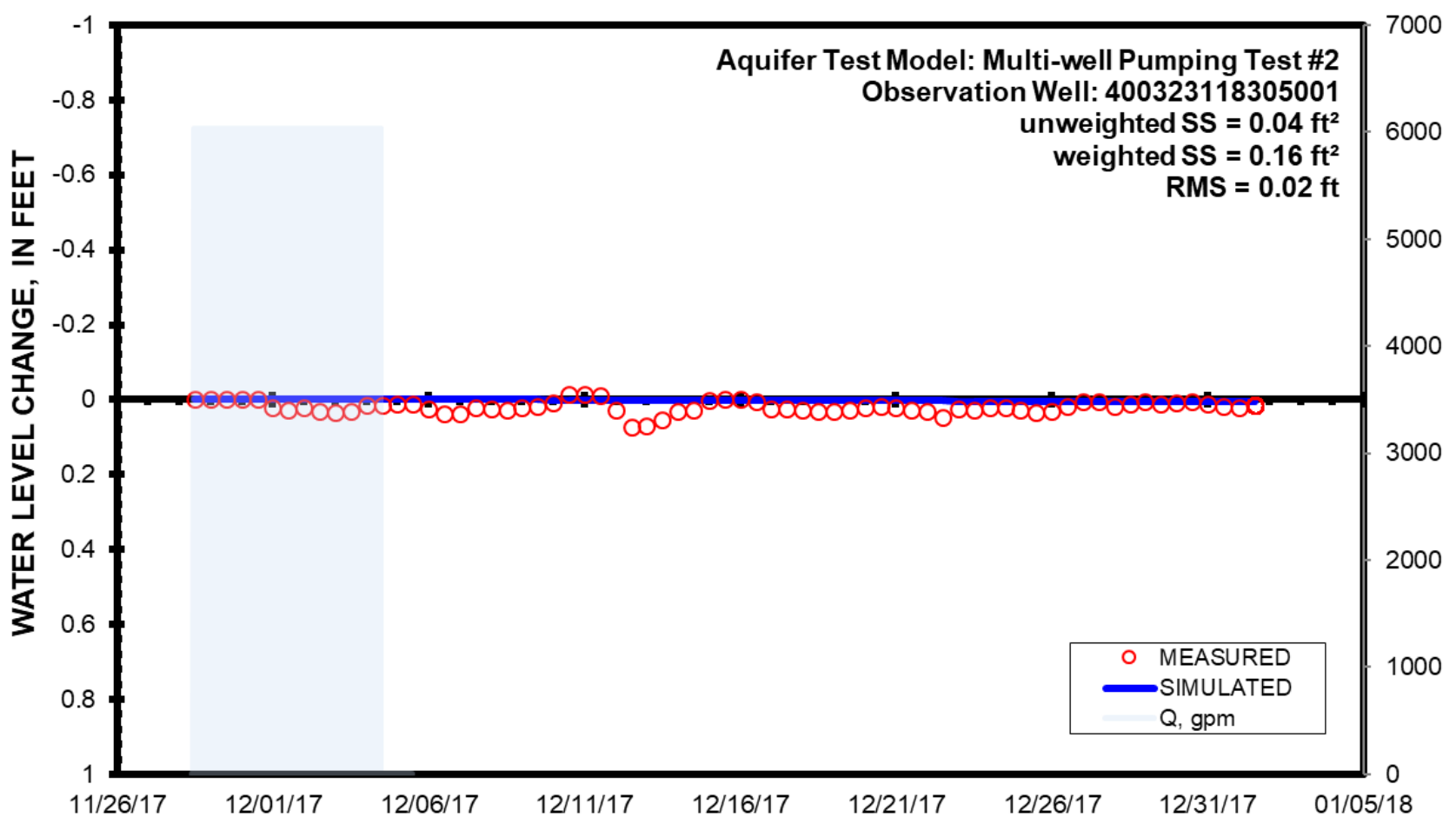

Figure 47. Simulated versus observed drawdown during multi-well pumping test \#2 (MWP2) for Well 16, located 9.6 miles from the pumping well in Lovelock Valley, Nevada. Pumping well discharge (0) in gallons per minute (gpm) is represented with the secondary $\mathrm{y}$-axis. [ft, foot; $\mathrm{ft}^{2}$, square foot; gpm, gallon per minute; SS, sum of square errors; RMS, root mean square error]

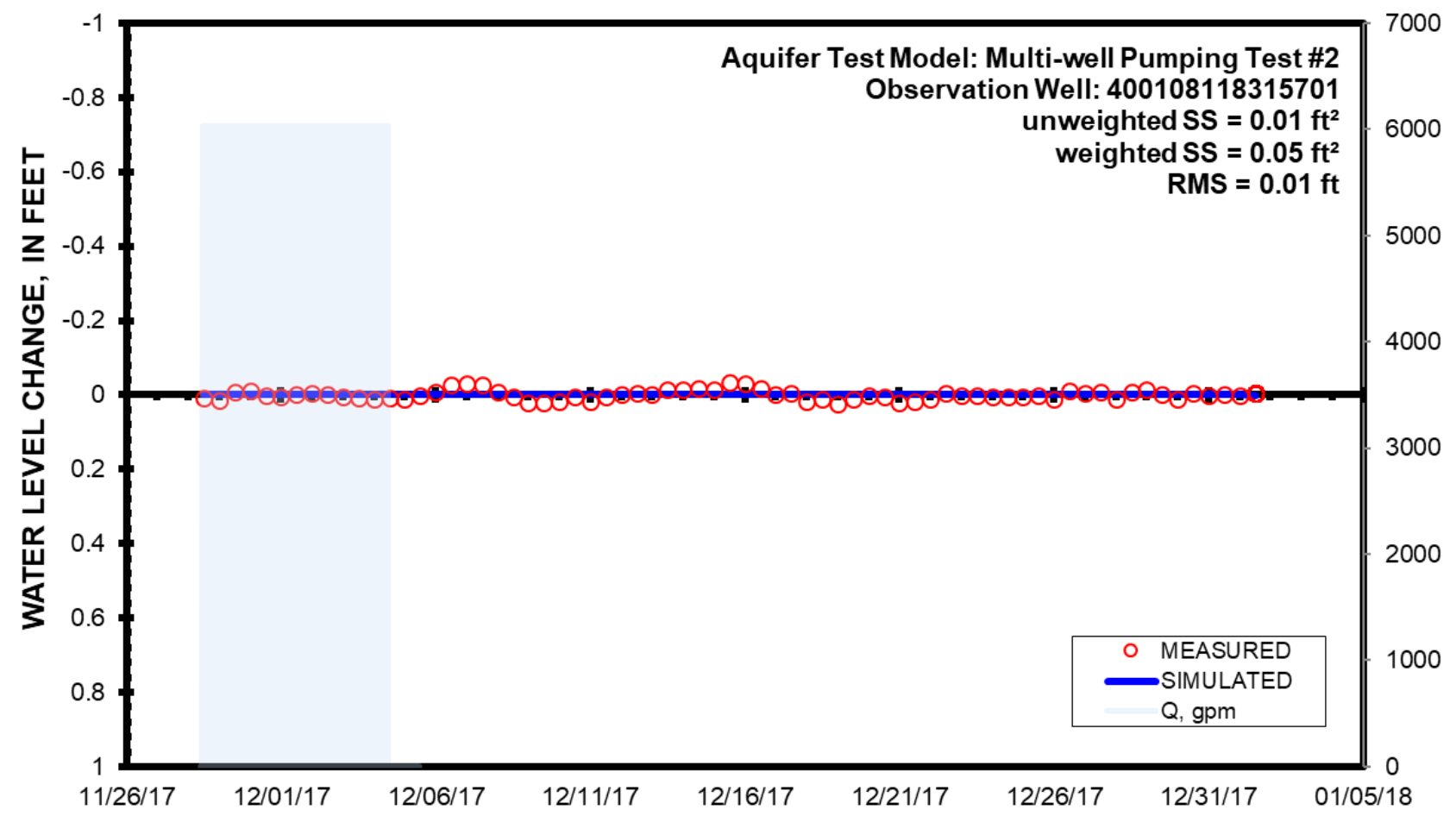

Figure 48. Simulated versus observed drawdown during multi-well pumping test \#2 (MWP2) for Well 17, located 12.3 miles from the pumping well in Lovelock Valley, Nevada. Pumping well discharge (0) in gallons per minute (gpm) is represented with the secondary $\mathrm{y}$-axis. [ft, foot; $\mathrm{ft}^{2}$, square foot; gpm, gallon per minute; SS, sum of square errors; RMS, root mean square error] 


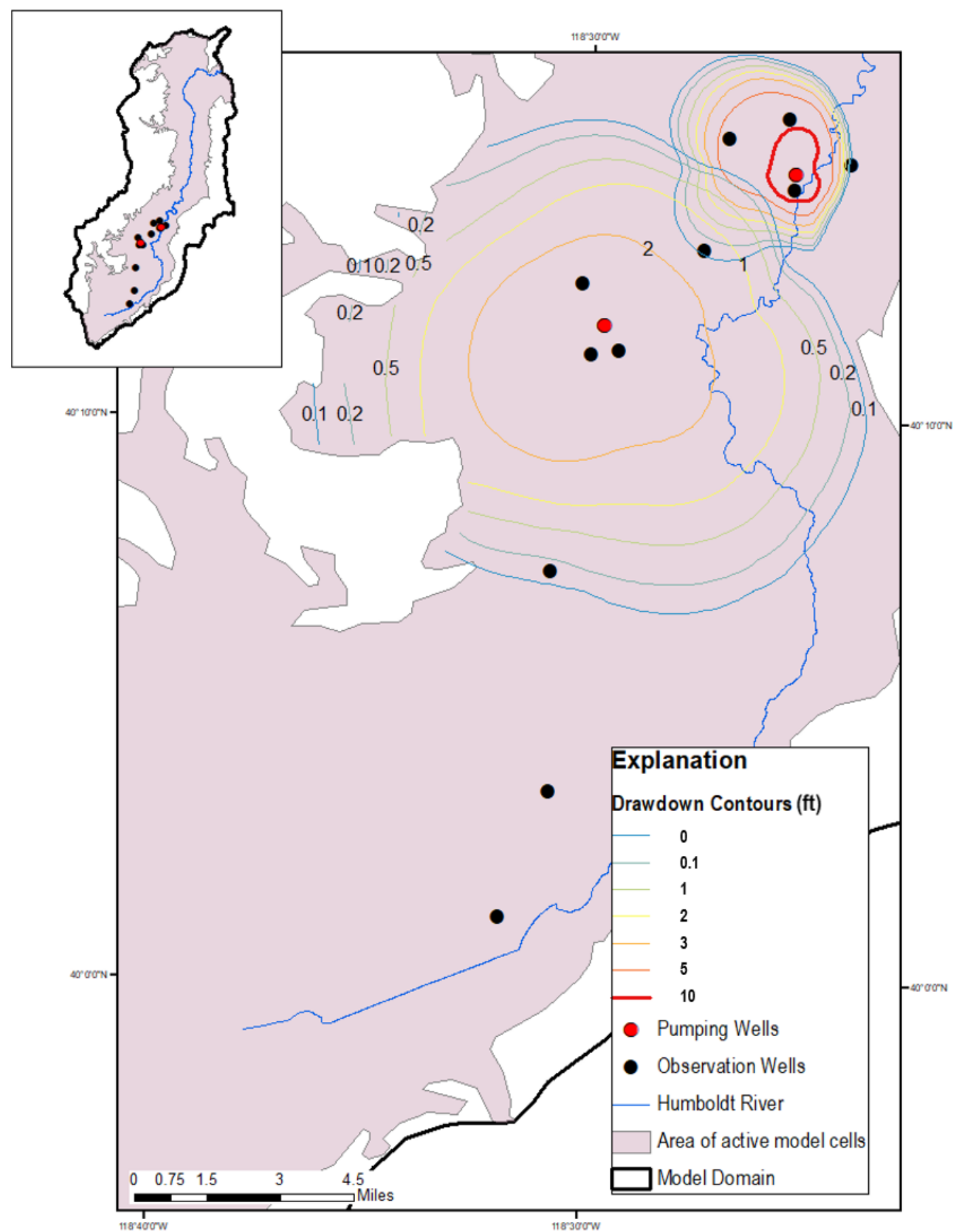

Figure 49. Drawdowns of variable contour intervals are shown after the wells were shut off and when drawdown was greatest from multi-well pumping tests \#1 and \#2 of Lovelock Valley, Nevada. The map extent is shown with a black rectangle in the inset map. [ft, foot] 


\section{Hydraulic Properties}

Hydraulic conductivity values of the Lahontan clays and silts, near-surface fluvial deposits, and coarser alluvium were estimated with two MODFLOW groundwater flow models. Hydraulic conductivity was multiplied by the saturated thickness in the model in order to express hydraulic properties as transmissivities, which are more directly comparable to results of independently-estimated aquifer test results. Transmissivity was greatest in the coarser alluvium and lowest in the Lahontan clays and silts (table 8; fig. 50). Transmissivity of the coarser alluvium ranged from $0.05 \mathrm{ft}^{2} /$ day to $95,000 \mathrm{ft}^{2} /$ day, with an average value of $11,000 \mathrm{ft}^{2} /$ day (fig. 50). Transmissivity of the Lahontan clays and silts ranged from $0.0001 \mathrm{ft}^{2} /$ day to $50 \mathrm{ft}^{2} /$ day, with an average value of $1 \mathrm{ft}^{2} /$ day. Transmissivity of the fluvial deposits ranged from $2.6 \mathrm{ft}^{2} /$ day to $53.8 \mathrm{ft}^{2} /$ day, with an average value of $14.1 \mathrm{ft}^{2} /$ day.

Well logs that include specific capacity data were used in a preliminary evaluation of the spatial variability of transmissivity across the valley. Wells screened in conceptual model layer 3 near the test area have the greatest transmissivity values near the two pumping wells. The transmissivity values decrease by one to two orders of magnitude with distance from the pumping wells. The overall trend of transmissivity values derived from specific capacity data somewhat fits the trend in model-derived transmissivity values (fig. 51). Everett and Rush (1965) described the coarser alluvium material represented in conceptual layer 3 as partly derived from the old channel of the Humboldt River and surrounding rivers. The exact extent of the old fluvial zone is unknown; however, the well-log derived transmissivities and interpretation of aerial photographs indicate the paleo river more thoroughly scoured the region surrounding the pumping wells. This interpretation agrees with the distribution of transmissivity in the numerical model that adequately simulates the drawdown distributions from both multi-well pumping tests.
Table 8. Estimated transmissivities of selected groupings of hydrostratigraphic units around locations of pumping wells in Lovelock Valley, Nevada.

[Transmissivity values are in $\mathrm{ft}^{2} / \mathrm{d}$, foot squared per day]

\begin{tabular}{lccc}
\hline Transmissivity & $\begin{array}{c}\text { Lahontan } \\
\text { clays and silts } \\
\left(\mathbf{f t}^{2} / \mathbf{d}\right)\end{array}$ & $\begin{array}{c}\text { Fluvial } \\
\text { deposits } \\
\left(\mathbf{f t}^{2} / \mathbf{d}\right)\end{array}$ & $\begin{array}{c}\text { Coarser } \\
\text { alluvium } \\
\left(\mathbf{f t}^{2} / \mathbf{d}\right)\end{array}$ \\
\hline Minimum & 0.0001 & 2.6 & 0.05 \\
Maximum & 50 & 53.8 & 95,000 \\
Average & 1 & 14.1 & 11,000 \\
\hline
\end{tabular}




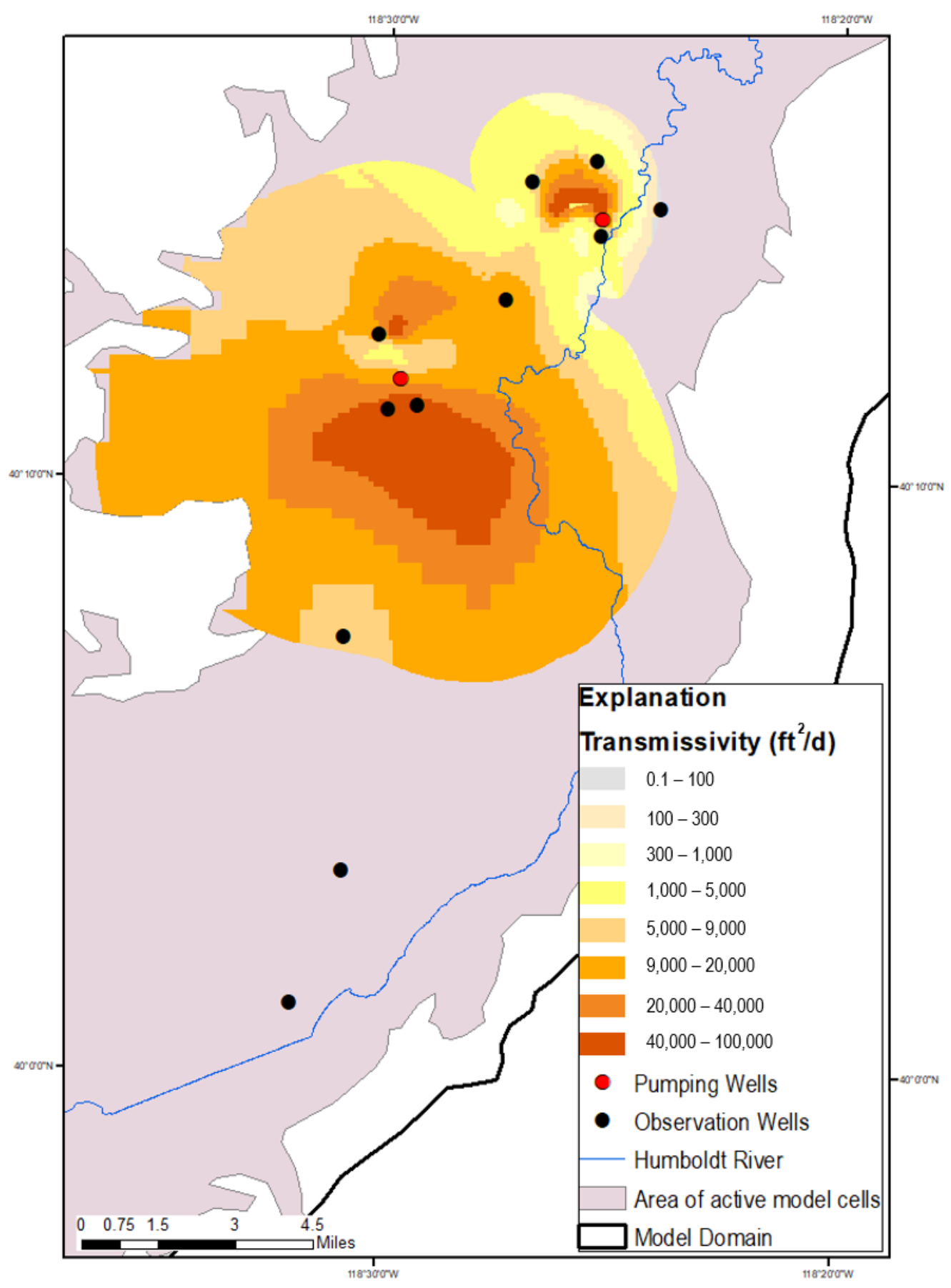

Figure 50. Simulated transmissivity in the area of observed drawdown from multi-well pumping tests \#1 and \#2 in Lovelock Valley, Nevada. Transmissivity is vertically-integrated to represent all three units of the younger alluvium. [ $\mathrm{ft}^{2} / \mathrm{d}$, foot squared per day] 


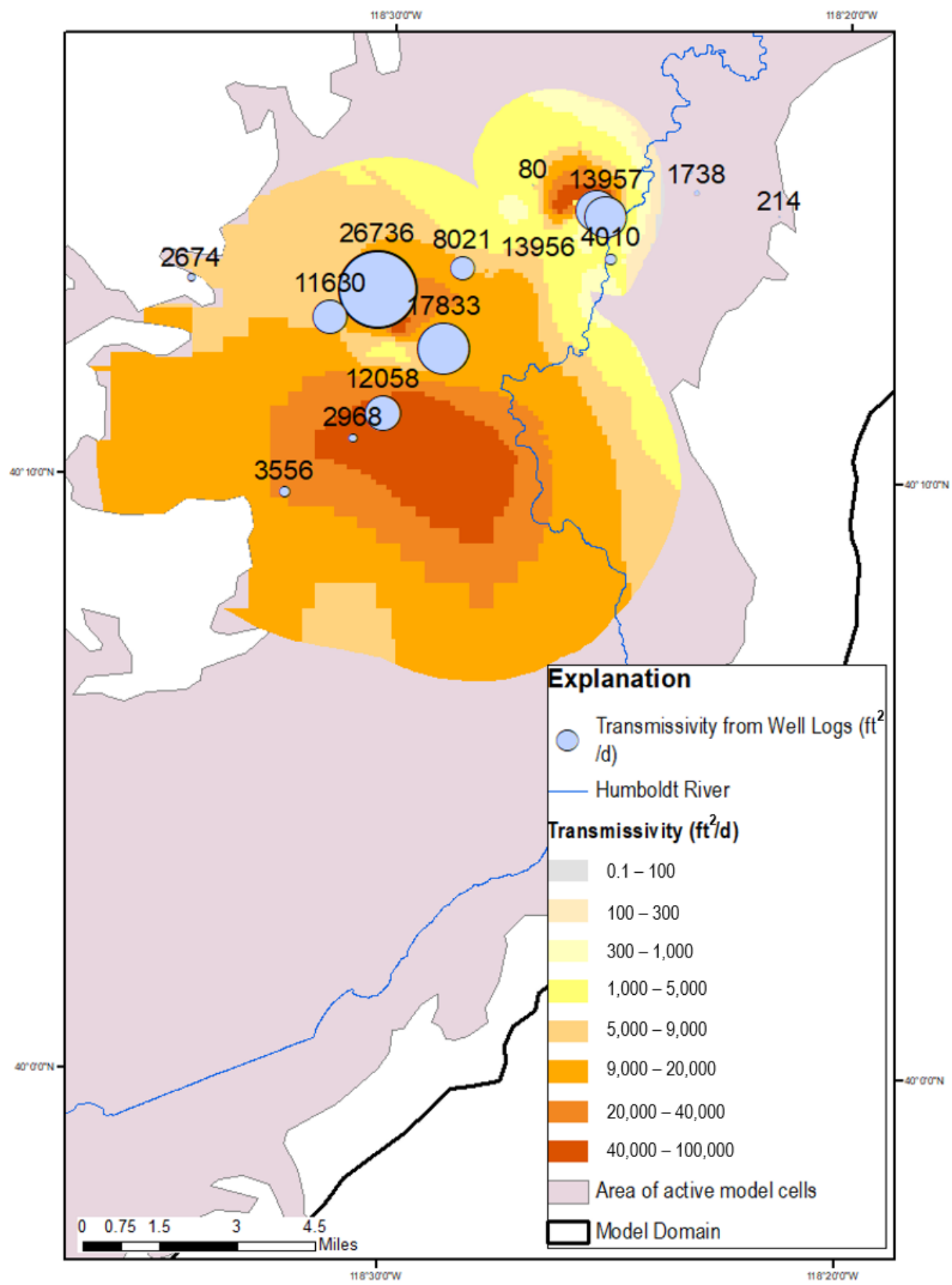

Figure 51. Transmissivity values calculated from well log-derived specific capacity values for wells screened at depths of 51 feet or greater in Lovelock Valley, Nevada. Well log-derived transmissivities are shown in purple circles scaled to transmissivity values (see labels). Well log-derived transmissivities overlay simulated transmissivity field. [ft²/d, square squared per day] 


\section{References Cited}

Barlow, P.M., and Leake, S.A., 2012, Streamflow depletion by wells-Understanding and managing the effects of groundwater pumping on streamflow: U.S. Geological Survey Circular 1376, 84 p., https://doi.org/10.3133/cir1376.

Bouwer, H., and Rice, R.C., 1976, A slug test for determining hydraulic conductivity of unconfined aquifers with completely or partially penetrating wells: Water Resources Research, v. 12, no. 3, p. 423-428, https://doi.org/10.1029/WR012i003p00423.

Cooper, H.H., Jr., and Jacob, C.E., 1946, A generalized graphical method for evaluating formation constants and summarizing well field history: EOS, Transactions of the American Geophysical Union, v. 27, no. 4, p. 526-534, https://doi.org/10.1029/TR027i004p00526.

Doherty, J.E., 2008, PEST-Model-independent parameter estimation: Brisbane, Australia, Watermark Numerical Computing.

Doherty, J.E., and Hunt, R.J., 2010, Approaches to highly parameterized inversion-A guide to using PEST for groundwater-model calibration: U.S. Geological Survey Scientific Investigations Report 2010-5169, 59 p., https://doi.org/10.3133/sir20105169.

Doherty, J.E., and Johnston, J.M., 2003, Methodologies for calibration and predictive analysis of a watershed model: Journal of the American Water Resources Association, v. 39, no. 2, p. 251-265, https://doi.org/10.1111/j.1752-1688.2003.tb04381.x.

Everett, D.E., and Rush, F.E., 1965, Water resources appraisal of Lovelock Valley, Pershing County, Nevada: Nevada Department of Conservation and Natural Resources, Water Resources-Reconnaissance Series Report 32, 41 p., http://images.water.nv.gov/images/publications/recon $\% 20$ reports/rpt32-lovelock_valley.pdf.

Fetter, C.W., Jr., 2001, Ground-water lows to Wells in Applied Hydrogeology (4th ed.):Upper Saddle River, N.J., PrenticeHall, p. 199-200.

Fienen, M.N., Muffels, C.T., and Hunt, R.J., 2009, On constraining pilot point calibration with regularization in PEST: Ground Water, v. 47, no. 6, p. 835-844, https://doi.org/10.1111/j.1745-6584.2009.00579.x.
Halford, K.J., 2006, Documentation of a spreadsheet for timeseries analysis and drawdown estimation: U.S. Geological Survey Scientific Investigations Report 2006-5024, 38 p., https://doi.org/10.3133/sir20065024.

Halford, K.J., and Kuniansky, E.L., 2002, Documentation of spreadsheets for the analysis of aquifer-test and slug-test data (ver. 1.1, May 2003): U.S. Geological Survey OpenFile Report 02-197, 51 p., https://doi.org/10.3133/ofr02197.

Harbaugh, A.W., Banta, E.R., Hill, M.C., and McDonald, M.G., 2000, MODFLOW-2000, the U.S. Geological Survey modular ground-water model-User guide to modularization concepts and the Ground-Water Flow Process: U.S. Geological Survey Open-File Report 00-92, 191 p., https://doi.org/10.3133/ofr200092.

Harbaugh, A.W., 2005, MODFLOW-2005, The U.S. Geological Survey modular ground-water modelThe ground-water flow process: U.S. Geological Survey Techniques and Methods, v. 6-A16, variously paginated, https://doi.org/10.3133/tm6A16.

Harp, D.R., and Vesselinov, V.V., 2011, Identification of pumping influences in long-term water level fluctuations: Ground Water, v. 49, no. 3, p. 403-414, https://doi.org/10.1111/j.1745-6584.2010.00725.x.

Leake, S.A., Leahy, P.P., and Navoy, A.S., 1994, Documentation of a computer program to simulate transient leakage from confining units using the modular finite-difference ground-water flow model: U.S. Geological Survey Open-File Report 94-59, 70 p., https://doi.org/10.3133/ofr9459.

Leake, S.A., and Prudic, D.E., 1988, Documentation of a computer program to simulate aquifer-system compaction using the modular finite-difference ground-water flow model: U.S. Geological Survey Open-File Report 88-482, 80 p., https://doi.org/10.3133/ofr88482.

Maurer, D.K., Lopes, T.J., Medina, R.L., and Smith, J.L., 2004, Hydrogeology and hydrologic landscape regions of Nevada: U.S. Geological Survey Scientific Investigations Report 2004-5131, 35 p., https://doi.org/10.3133/sir20045131.

Nadler, C.A., 2020, Supplemental data for analysis of aquifer framework and hydraulic properties of Lovelock Valley, Lovelock, NV: U.S. Geological Survey data release, https://doi.org/10.5066/P9LIL7PZ. 
For more information concerning the research in this report, contact the Nevada Water Science Center

U.S. Geological Survey

2730 N. Deer Run Road

Carson City, Nevada 95819

https://www.usgs.gov/centers/nv-water

Publishing support provided by the U.S. Geological Survey Science Publishing Network, Sacramento Publishing Service Center 


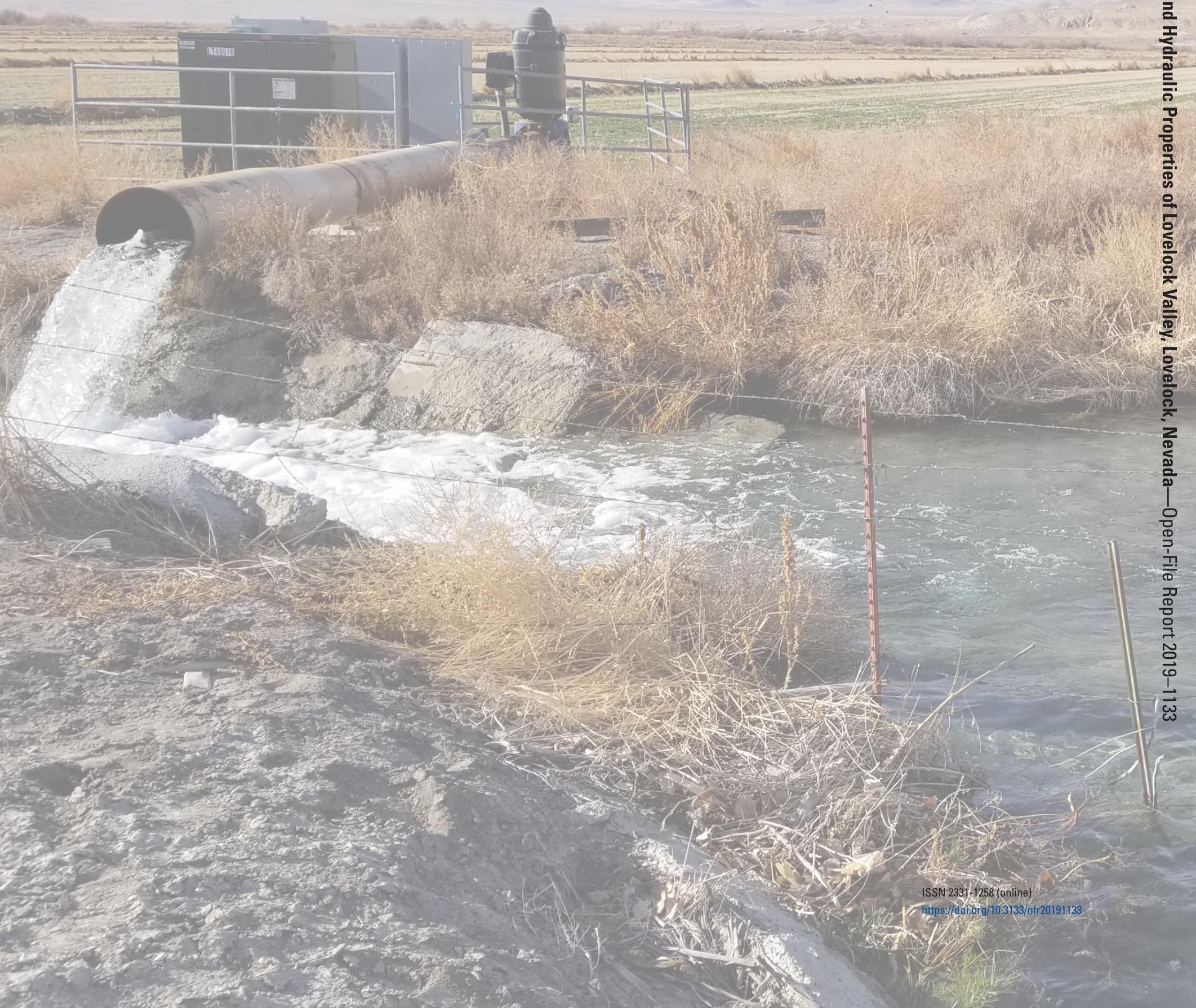

